\title{
Summary Report of Two-Dimensional Analysis of Radiochemical Assay Samples
}

by

Carl Connell

John M. Scaglione

Prepared for:

U.S. Department of Energy

Yucca Mountain Site Characterization Office P.O. Box 30307

North Las Vegas, Nevada 89036-0307

Prepared by:

Bechtel SAIC Company, LLC

1180 Town Center Drive

Las Vegas, Nevada 89144

Under Contract Number

DE-AC08-01RW12101 


\section{DISCLAIMER}

This report was prepared as an account of work sponsored by an agency of the United States Government. Neither the United States Government nor any agency thereof, nor any of their employees, nor any of their contractors, subcontractors or their employees, makes any warranty, express or implied, or assumes any legal liability or responsibility for the accuracy, completeness, or any third party's use or the results of such use of any information, apparatus, product, or process disclosed, or represents that its use would not infringe privately owned rights. Reference herein to any specific commercial product, process, or service by trade name, trademark, manufacturer, or otherwise, does not necessarily constitute or imply its endorsement, recommendation, or favoring by the United States Government or any agency thereof or its contractors or subcontractors. The views and opinions of authors expressed herein do not necessarily state or reflect those of the United States Government or any agency thereof. 
Bechtel SAIC Company, LLC.

Summary Report of Two-Dimensional Analysis of Radiochemical Assay Samples

TDR-UDC-NU-000006 REV 00

December 2001

Prepared by:

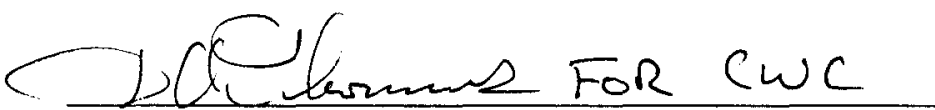

C.W. Connell

Waste Package Criticality

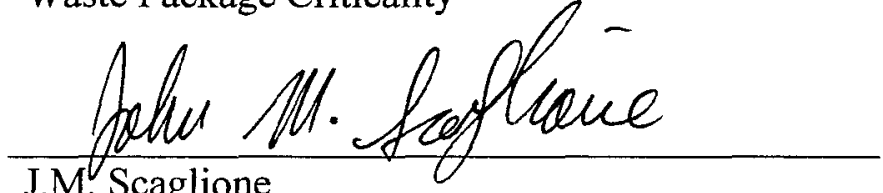

Waste Package Criticality

Reviewed by:

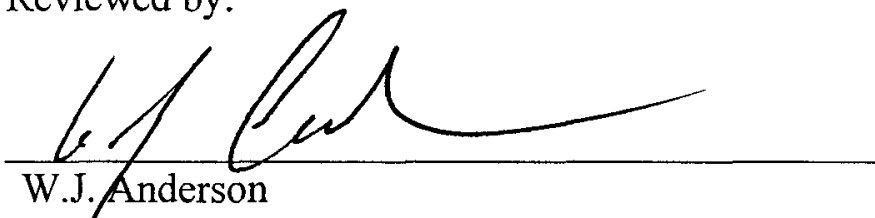

Technical Checker, Waste Package Criticality

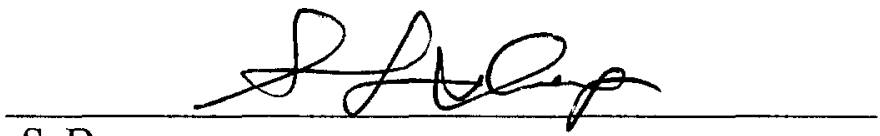

S. Deng

Compliance Checker, Waste Package Criticality

Approved by:

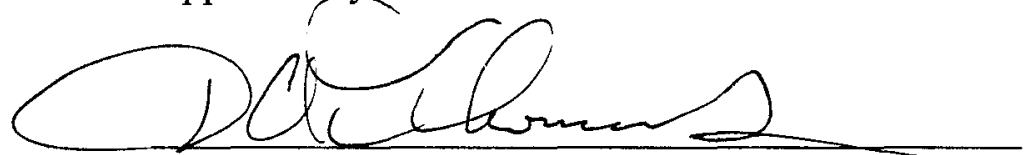

D.A. Thomas

Manager, Waste Package Criticality $\frac{12 / 03 / 2001}{\text { Date }}$

$\frac{12 / 3 / 2001}{\text { Date }}$

12/03/2001

Date

$12 / 03 / 2001$

Date

$$
\frac{12 / 03 / 2001}{\text { Date }}
$$


INTENTIONALLY LEFT BLANK 


\section{CONTENTS}

Page

1. INTRODUCTION .............................................................................................. 1

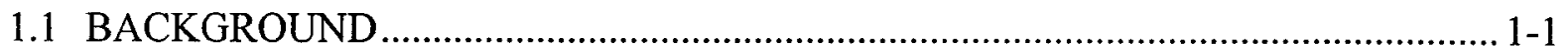

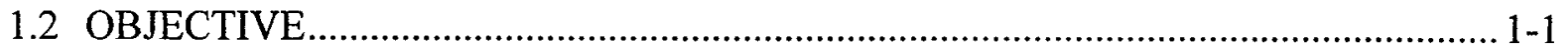

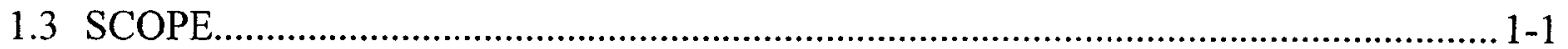

1.4 QUALITY ASSURANCE ............................................................................ 1-2

1.5 USE OF COMPUTER SOFTWARE ............................................................. $1-2$

2. CALCULATION DESCRIPTIONS ...................................................................... 2-1

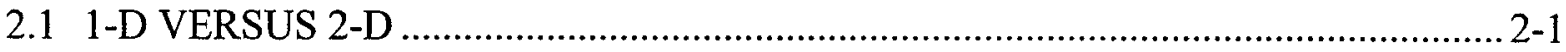

2.2 PRESSURIZED WATER REACTORS …........................................................ 2-1

2.2.1 Calvert Cliffs........................................................................................ 2-2

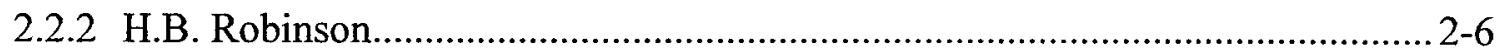

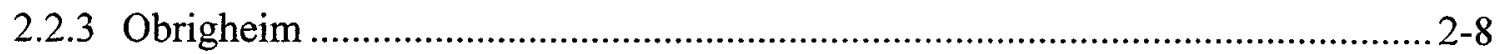

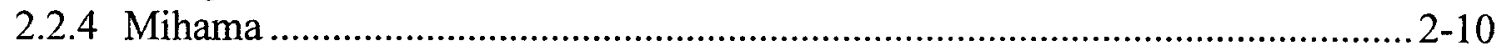

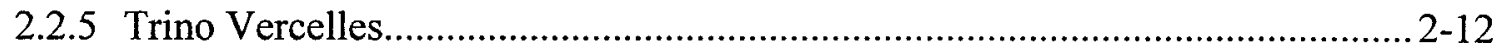

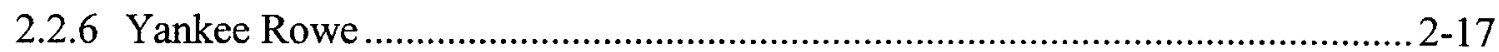

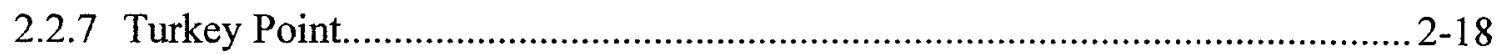

2.3 BOILING WATER REACTORS ............................................................... 2-20

2.3.1 Cooper............................................................................................ 2-20

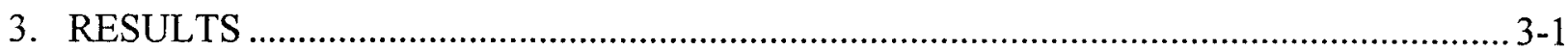

3.1 PRESSURIZED WATER REACTORS …....................................................... 3-1

3.1.1 Calvert Cliffs.......................................................................................... $3-1$

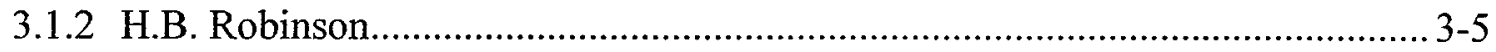

3.1.3 Obrigheim ....................................................................................... 3-8

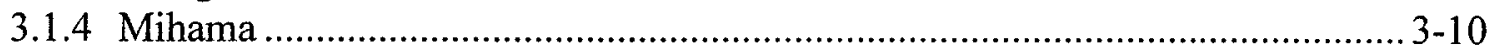

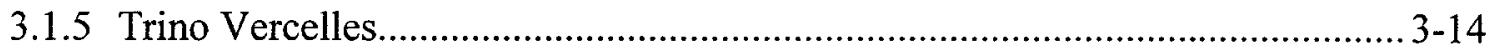

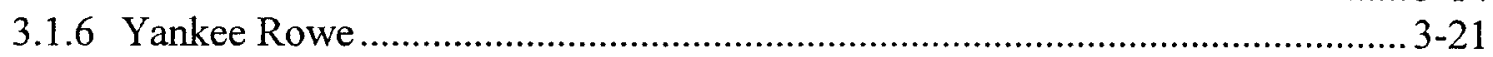

3.1.7 Turkey Point........................................................................................ 3-25

3.2 BOILING WATER REACTORS ................................................................. 3-28

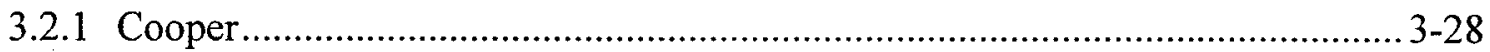

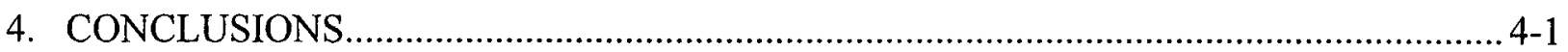

5. REFERENCES .................................................................................................... $5-1$

5.1 DOCUMENTS CITED ….............................................................................. $5-1$

5.2 SOURCE DATA, LISTED BY DATA TRACKING NUMBER .............................5-2

APPENDIX A: SUMMARY PLOTS OF COMPARISON ............................................... A-1 
INTENTIONALLY LEFT BLANK 


\section{FIGURES}

2-1. Location of Fuel Rod NBD107 in FA BT03 ……......................................................... 2-3

2-2. Location of Fuel Rod MKP109 in FA D047 …….......................................................... 2-4

2-3. Location of Fuel Rod MLA098 in FA D101 ……...................................................... 2-5

2-4. Cross Section of the H.B. Robinson Fuel Assembly ..................................................... 2-7

2-5. Cross Section of the Obrigheim Fuel Assembly ............................................................... 2-9

2-6. Cross Section of the Mihama Fuel Assembly ..............................................................2-11

2-7. Cross Section of the Square and Cruciform Assemblies for Trino Vercelles ...................2-13

2-8. Fuel Rod Location for Trino Vercelles Assembly 509-032 ........................................... 2-14

2-9. Fuel Rod Location for Trino Vercelles Assembly 509-069 ……...................................2-15

2-10. Fuel Rod Location for Trino Vercelles Assembly 509-104 ........................................... 2-16

2-11. Fuel Rod Location for Yankee Rowe Assembly E6 ...................................................... 2-18

2-12. Cross Section of the Turkey Point Fuel Assembly ………………….............................2-19

2-13. Cross Section of the Control Blade and Fuel Assembly for Cooper ..............................2-21

3-1. Calvert Cliffs U-235 Comparison............................................................................... 3-4

3-2. Calvert Cliffs U-238 Comparison................................................................................. 3-5

3-3. Calvert Cliffs Pu-239 Comparison .......................................................................... 3-5

3-4. H.B. Robinson U-235 Comparison........................................................................... 3-7

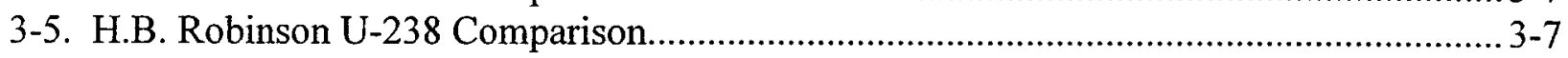

3-6. H.B. Robinson Pu-239 Comparison ....................................................................... 3-8

3-7. Obrigheim U-235 Comparison .......................................................................... 3-10

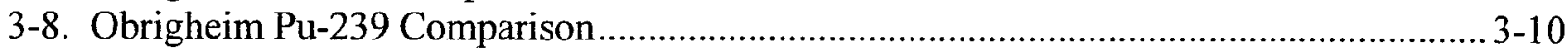

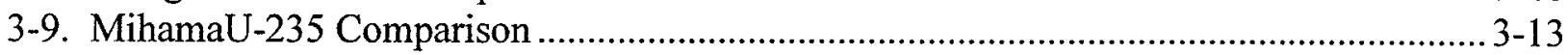

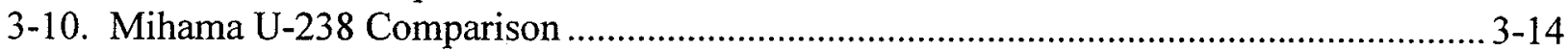

3-11. Mihama Pu-239 Comparison ................................................................................ 3-14

3-12. Trino Vercelles U-235 Comparison ..................................................................... 3-20

3-13. Trino Vercelles U-238 Comparison .................................................................. 3-20

3-14. Trino Vercelles Pu-239 Comparison ........................................................................ 3-21

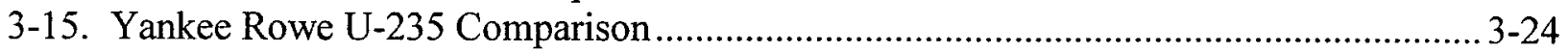

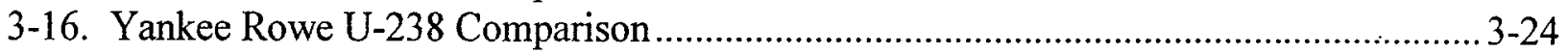

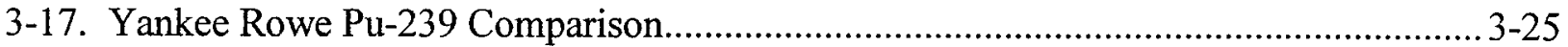

3-18. Turkey Point U-235 Comparison ...................................................................... 3-27

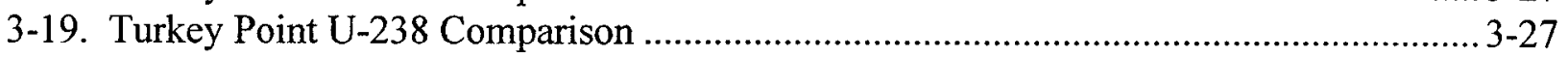

3-20. Turkey Point Pu-239 Comparison ......................................................................... 3-28

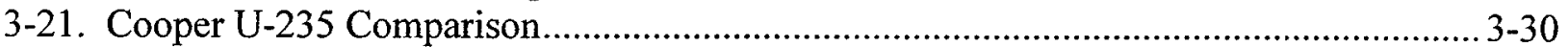

3-22. Cooper U-238 Comparison..................................................................................

3-23. Cooper Pu-239 Comparison .............................................................................. 3-31

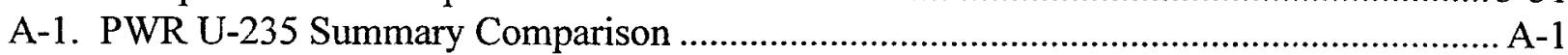

A-2. PWR U-238 Summary Comparison ………………........................................... A-1

A-3. PWR Pu-239 Summary Comparison ..................................................................... 
INTENTIONALLY LEFT BLANK 


\section{TABLES}

2-1. PWR Plants for SNF Analyzed

3-1. Calvert Cliffs BT03, NBD107 $\left(\mathrm{AL}^{\mathrm{a}}=11.28 \mathrm{~cm}\right.$, Burnup $\left.=31.4 \mathrm{GWd} / \mathrm{mtU}\right) \ldots \ldots \ldots \ldots \ldots . . . . . . .1$

3-2. Calvert Cliffs BT03, NBD107 $(\mathrm{AL}=19.92 \mathrm{~cm}$, Burnup $=37.24 \mathrm{GWd} / \mathrm{mtU}) \ldots \ldots \ldots \ldots \ldots . . . . . .2$

3-3. Calvert Cliffs BT03, NBD107 $(\mathrm{AL}=161.21 \mathrm{~cm}$, Burnup $=46.46 \mathrm{GWd} / \mathrm{mtU}) \ldots \ldots \ldots \ldots \ldots . . . . . .3-2$

3-4. Calvert Cliffs D047, MKP109 $(\mathrm{AL}=13.2 \mathrm{~cm}$, Burnup $=27.35 \mathrm{GWd} / \mathrm{mtU}) \ldots \ldots \ldots \ldots \ldots \ldots . . . . . . .2$

3-5. Calvert Cliffs D047, MKP109 (AL $=27.7 \mathrm{~cm}$, Burnup $=37.12 \mathrm{GWd} / \mathrm{mtU}) \ldots \ldots \ldots \ldots \ldots \ldots . . . . . . .3-2$

3-6. Calvert Cliffs D047, MKP109 (AL = $165.22 \mathrm{~cm}$, Burnup $=44.34 \mathrm{GWd} / \mathrm{mtU}) \ldots \ldots \ldots \ldots \ldots . . . . . .3-3$

3-7. Calvert Cliffs D101, MLA098 (AL $=8.9 \mathrm{~cm}$, Burnup $=18.68 \mathrm{GWd} / \mathrm{mtU}) \ldots \ldots \ldots \ldots \ldots \ldots . . . . . . .3-3$

3-8. Calvert Cliffs D101, MLA098 (AL $=24.3 \mathrm{~cm}$, Burnup $=26.62 \mathrm{GWd} / \mathrm{mtU}) \ldots \ldots \ldots \ldots \ldots \ldots . . . . . . .3-3$

3-9. Calvert Cliffs D101, MLA098 $(\mathrm{AL}=161.7 \mathrm{~cm}$, Burnup $=33.17 \mathrm{GWd} / \mathrm{mtU}) \ldots \ldots \ldots \ldots \ldots . . . . . . .4$

3-10. H.B. Robinson PWR Sample N-9B-S $(\mathrm{AL}=11 \mathrm{~cm}$, Burnup $=16.02 \mathrm{GWd} / \mathrm{mtU}) \ldots \ldots \ldots . .6$

3-11. H.B. Robinson PWR Sample N-9B-N (AL $=26 \mathrm{~cm}$, Burnup $=23.81 \mathrm{GWd} / \mathrm{mtU})$......... 3-6

3-12. H.B. Robinson PWR Sample N-9C-J (AL $=199 \mathrm{~cm}$, Burnup $=28.47 \mathrm{GWd} / \mathrm{mtU}) \ldots \ldots \ldots .3-6$

3-13. H.B. Robinson PWR Sample N-9C-D (AL $=226 \mathrm{~cm}$, Burnup $=31.66 \mathrm{GWd} / \mathrm{mtU}) \ldots \ldots .3-6$

3-14. Obrigheim PWR TA 168 (Batch 86, Burnup = 28.40 GWd/mtU).............................. 3-8

3-15. Obrigheim PWR TA 170 (Batch 94, Burnup = 25.93 GWd/mtU) .............................. 3-8

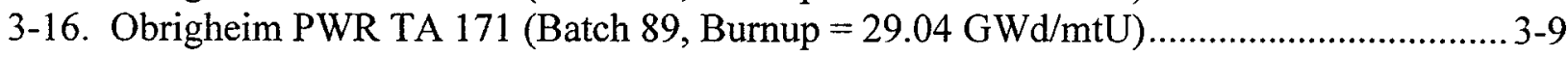

3-17. Obrigheim PWR TA 172 (Batch 92, Burnup = 26.54 GWd/mtU) ................................ 3-9

3-18. Obrigheim PWR TA 176 (Batch 90, Burnup = 29.52 GWd/mtU) ............................. 3-9

3-19. Obrigheim PWR TA 176 (Batch 91, Burnup = 27.99 GWd/mtU) ..................................3-9

3-20. Mihama PWR Sample 86b02 (Burnup = 8.30 GWd/mtU) ...................................... 3-11

3-21. Mihama PWR Sample 86b03 (Burnup $=6.92 \mathrm{GWd} / \mathrm{mtU})$...................................... 3-11

3-22. Mihama PWR Sample 86g03 (Burnup $=21.29 \mathrm{GWd} / \mathrm{mtU})$..................................... 3-11

3-23. Mihama PWR Sample 86g05 (Burnup $=15.36 \mathrm{GWd} / \mathrm{mtU})$...................................... 3-11

3-24. Mihama PWR Sample 86g07 (Burnup = $14.66 \mathrm{GWd} / \mathrm{mtU})$....................................... 3-12

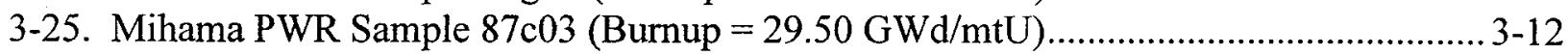

3-26. Mihama PWR Sample 87c04 (Burnup = 32.20 GWd/mtU) ..................................... 3-12

3-27. Mihama PWR Sample 87c07 (Burnup = 33.71 GWd/mtU) ...................................... 3-13

3-28. Mihama PWR Sample 87c08 (Burnup = 34.32 GWd/mtU) ................................... 3-13

3-29. Trino Vercelles FA 509-104 $(\operatorname{Rod} M 11, A L=79.2 \mathrm{~cm}$, Burnup $=12.04 \mathrm{GWd} / \mathrm{mtU}) \ldots 3-15$

3-30. Trino Vercelles FA 509-032 $(\operatorname{Rod} E 11, \mathrm{AL}=158.5 \mathrm{~cm}$, Burnup $=15.38 \mathrm{GWd} / \mathrm{mtU}) . .3-15$

3-31. Trino Vercelles FA 509-032 (Rod E11, AL = 79.2 cm, Burnup = $15.90 \mathrm{GWd} / \mathrm{mtU}) \ldots .3-15$

3-32. Trino Vercelles FA 509-032 (Rod E11, AL $=26.4 \mathrm{~cm}$, Burnup $=11.53 \mathrm{GWd} / \mathrm{mtU}) \ldots .3-16$

3-33. Trino Vercelles FA 509-069 (Rod E11, AL $=237.7 \mathrm{~cm}$, Burnup $=12.86 \mathrm{GWd} / \mathrm{mtU}) . .3-16$

3-34. Trino Vercelles FA 509-069 (Rod E11, AL $=211.3 \mathrm{~cm}$, Burnup $=20.6 \mathrm{GWd} / \mathrm{mtU}) \ldots .3-16$

3-35. Trino Vercelles FA 509-069 (Rod E11, AL $=158.5 \mathrm{~cm}$, Burnup $=23.72 \mathrm{GWd} / \mathrm{mtU}) . .3-17$

3-36. Trino Vercelles FA 509-069 (Rod E11, AL $=79.2 \mathrm{~cm}$, Burnup $=24.30 \mathrm{GWd} / \mathrm{mtU})$.... 3-17

3-37. Trino Vercelles FA 509-069 (Rod E05, $\mathrm{AL}=158.5 \mathrm{~cm}$, Burnup $=23.87 \mathrm{GWd} / \mathrm{mtU}) . .3-17$

3-38. Trino Vercelles FA 509-069 (Rod E05, AL $=79.2 \mathrm{~cm}$, Burnup $=24.55 \mathrm{GWd} / \mathrm{mtU}) \ldots . .3-18$

3-39. Trino Vercelles FA 509-069 (Rod L11, AL $=158.5 \mathrm{~cm}$, Burnup $=23.93 \mathrm{GWd} / \mathrm{mtU}) . .3-18$

3-40. Trino Vercelles FA 509-069 (Rod L11, AL $=79.2 \mathrm{~cm}$, Burnup $=24.36 \mathrm{GWd} / \mathrm{mtU})$.... 3-18

3-41. Trino Vercelles FA 509-069 (Rod L05, AL $=158.5 \mathrm{~cm}$, Burnup $=24.33 \mathrm{GWd} / \mathrm{mtU}) . .3-19$

3-42. Trino Vercelles FA 509-069 (Rod L05, AL $=79.2 \mathrm{~cm}$, Burnup $=24.31 \mathrm{GWd} / \mathrm{mtU}) \ldots .3-19$

3-43. Yankee Rowe FA E6-SE-c2 $(\mathrm{AL}=57.66 \mathrm{~cm}$, Burnup $=31.41 \mathrm{GWd} / \mathrm{mtU}) \ldots \ldots \ldots \ldots \ldots . . . . . . .21$ 


\section{TABLES (Continued)}

3-44. Yankee Rowe FA E6-SE-c2 $(\mathrm{AL}=138.94 \mathrm{~cm}$, Burnup $=32.03 \mathrm{GWd} / \mathrm{mtU})$.

3-45. Yankee Rowe FA E6-SE-e4 (AL $=57.66 \mathrm{~cm}$, Burnup $=35.26 \mathrm{GWd} / \mathrm{mtU})$.

3-46. Yankee Rowe FA E6-SE-e4 $(\mathrm{AL}=138.94 \mathrm{~cm}$, Burnup $=35.97 \mathrm{GWd} / \mathrm{mtU})$.

3-47. Yankee Rowe FA E6-C-f6 $(\mathrm{AL}=17.02 \mathrm{~cm}$, Burnup $=20.19 \mathrm{GWd} / \mathrm{mtU})$.

3-48. Yankee Rowe FA E6-C-f6 $(\mathrm{AL}=57.66 \mathrm{~cm}$, Burnup $=31.33 \mathrm{GWd} / \mathrm{mtU})$

3-49. Yankee Rowe FA E6-C-f6 (AL $=138.94 \mathrm{~cm}$, Burnup $=30.39 \mathrm{GWd} / \mathrm{mtU})$

3-50. Yankee Rowe FA E6-C-f6 $(\mathrm{AL}=220.22 \mathrm{~cm}$, Burnup $=15.95 \mathrm{GWd} / \mathrm{mtU})$

3-51. Turkey Point FA D01 (Rod G09, Burnup $=30.72 \mathrm{GWd} / \mathrm{mtU})$

3-52. Turkey Point FA D01 $(\operatorname{Rod} \mathrm{G} 10$, Burnup $=30.51 \mathrm{GWd} / \mathrm{mtU})$

3-53. Turkey Point FA D01 $(\operatorname{Rod} H 09$, Burnup $=31.56 \mathrm{GWd} / \mathrm{mtU})$

3-54. Turkey Point FA D04 (Rod G09, Burnup $=31.26 \mathrm{GWd} / \mathrm{mtU})$

3-55. Turkey Point FA D04 (Rod G10, Burnup $=31.31 \mathrm{GWd} / \mathrm{mtU})$

3-56. Cooper Sample ADD2966-B $\left(\mathrm{AL}=55.1 \mathrm{~cm}, \mathrm{VOI}^{\mathrm{a}}=2.59\right.$, Burnup $=18.96$ $\mathrm{GWd} / \mathrm{mtU}$ )

3-57. Cooper Sample ADD2966-K $(\mathrm{AL}=218.9 \mathrm{~cm}, \mathrm{VOI}=60.9$, Burnup $=33.07$ $\mathrm{GWd} / \mathrm{mtU})$

3-58. Cooper Sample ADD2966- $\mathrm{T}(\mathrm{AL}=274.8 \mathrm{~cm}, \mathrm{VOI}=66.56, \mathrm{Burnup}=33.94$ $\mathrm{GWd} / \mathrm{mtU})$

3-59. Cooper Sample ADD2974-B $(\mathrm{AL}=55.7 \mathrm{~cm}, \mathrm{VOI}=2.9$, Burnup $=17.84$ $\mathrm{GWd} / \mathrm{mtU}$ )

3-60. Cooper Sample ADD2974-J $(\mathrm{AL}=115.0 \mathrm{~cm}, \mathrm{VOI}=29.0$, Burnup $=29.23$ $\mathrm{GWd} / \mathrm{mtU}$ ).

3-61. Cooper Sample ADD2974-U $(A L=291.0 \mathrm{~cm}, \mathrm{VOI}=68.0$, Burnup $=31.04$ $\mathrm{GWd} / \mathrm{mtU}$ ). 


\section{ACRONYMS AND ABBREVIATIONS}

\section{Acronyms}

$\begin{array}{ll}\text { APSR } & \text { Axial Power Shaping Rod } \\ \text { AROCB } & \text { all rods out critical boron } \\ \text { BWR } & \text { boiling water reactor } \\ \text { NRC } & \text { U.S. Nuclear Regulatory Commission } \\ \text { PWR } & \text { pressurized water reactor } \\ \text { QARD } & \text { Quality Assurance Requirements and Description } \\ \text { RCA } & \text { radiochemical assay } \\ \text { SNF } & \text { spent nuclear fuel }\end{array}$

$\begin{array}{ll}\text { Abbreviations } & \\ \text { AL } & \text { axial location from bottom of fuel } \\ \text { FA } & \text { fuel assembly } \\ \text { ID } & \text { inside diameter } \\ \text { mtU } & \text { metric ton uranium } \\ \text { OD } & \text { outside diameter } \\ \text { ppmB } & \text { parts per million Boron } \\ \text { VOI } & \text { Void percent } \\ \text { W } & \text { Westinghouse } \\ \text { wt } \% & \text { weight percent }\end{array}$


INTENTIONALLY LEFT BLANK 


\section{INTRODUCTION}

The Summary Report of Two-Dimensional Analysis of Radiochemical Assay Samples report provides a summary of the analyses comparing calculated isotopics generated by a pointdepletion code that uses one-dimensional (1-D) neutron transport theory weighted cross-sections (SAS2H Control Module of the SCALE Modular Code System) and a two-dimensional (2-D) depletion code (GRCASMO3) with that of radiochemical assay (RCA) results.

\subsection{BACKGROUND}

The United States Department of Energy Office of Civilian Radioactive Waste Management (OCRWM) is developing a methodology for criticality analysis to support disposal of commercial spent nuclear fuel in a geologic repository. A topical report on the disposal criticality analysis methodology was submitted to the United States Nuclear Regulatory Commission (NRC) for formal review in March 2001 (YMP 2000). This summary report provides data that was and will be used in analyses that will support the validation of parts of the disposal criticality analysis methodology. This technical report is prepared per Technical Work Plan for: Waste Package Design Description for LA (BSC 2001).

\subsection{OBJECTIVE}

The objective of the 2-D Analysis of Radiochemical Assay Samples is to present a summary of the computational and radiochemical assay analyses for spent nuclear fuel (SNF) from seven pressurized water reactors (PWRs) and one boiling water reactor (BWR). Results of this work are an indication of the accuracy of SAS2H and GRCASMO3 for generating SNF isotopic concentrations, which will be used as input for criticality analyses for SNF storage at the potential Monitored Geologic Repository.

\subsection{SCOPE}

The scope of this report is to compare measured SNF isotopic concentrations to calculated isotopic concentrations for the following reactors:

- Calvert Cliffs PWR

- Cooper BWR

- H.B. Robinson PWR

- Mihama PWR

- Obrigheim PWR

- Trino Vercelles PWR

- Turkey Point PWR

- Yankee Rowe PWR 


\subsection{QUALITY ASSURANCE}

The development of the this report has been subject to the United States Department of Energy OCRWM Quality Assurance Requirements and Description (QARD) (DOE 2000) controls. The information provided in this report will be used to develop the methodology for evaluation of the potential Monitored Geologic Repository engineered barrier system. A number of classification analyses (e.g., CRWMS M\&O [1999, Section 7]) have identified components of the engineered barrier system as items important to radiological safety and waste isolation.

No scientific and engineering software or computational software was used in the development of this report. Electronic management of data was accomplished in accordance with the controls specified in the Technical Work Plan (BSC 2001).

The work that is to be performed to support the License Application using this information will be performed in accordance with the then current versions of the QARD and NRC regulations. All information used for the License Application will be from acceptable sources and will be developed in accordance with the QARD requirements and NRC regulations.

\subsection{USE OF COMPUTER SOFTWARE}

No computer software subject to the QARD was used in the development of this report. The results reported in this document were drawn from various documents, which did use software subject to the requirements of the QARD. The details of the computer software approved for quality affecting work used to generate the results are provided in the various individual documents referenced by this report. 


\section{CALCULATION DESCRIPTIONS}

This section provides a general description of the radiochemical assay samples analyzed in the supporting evaluations. The specific rod and fuel assembly location the sample was taken from, as well as the reactor operating conditions used in the supporting calculations are provided.

\subsection{1-D VERSUS 2-D}

Other than the obvious differences between preparing a calculation in 2-D versus 1-D, there are a few differences in the use of GRCASMO3 for fuel burnup calculations as opposed to SAS2H. The input file generally requires the specific dimensions and materials of the fuel pellets, cladding, and guide tubes, as well as the pitch of the fuel rods and fuel assemblies (FAs), and the dimensions of the narrow and wide gaps between FAs. In GRCASMO3 the code builds a fuel assembly/fuel pin analysis model from the FA characteristics provided in the input specifications. In SAS2H, 1-D transport calculations are performed on two models, Path A and Path B, to calculate energy dependent spatial neutron flux distributions necessary to perform cross section cell-weighting calculations. A detailed description of the calculations used to produce time-dependent cross sections by SAS2H is documented in NRC (1997, Volume 1, Section S2.2.4).

Burnup is specified in SAS2H by specific power over a number of days. GRCASMO3 has specific power and the burnup value as input directly. In the calculations using SAS2H, the fuel pins that were analyzed (RCA) for burnup and isotopic concentrations were modeled and calculated by simulating reactor operations to the analyzed burnup. In many cases, the operating days in a cycle were estimated by dividing the analyzed burnup by the average specific power for a particular fuel cycle. Generally, the inputs for SAS2H to the degree allowable were used as the source of the input parameters for GRCASMO3. In the GRCAMSO3 cases, a FA was modeled and the fuel burnup for that FA was adjusted until the correct burnup value from the RCAanalyzed fuel pin was reached. In cases where several samples came from the same fuel pin, then the calculations were made for each sample separately to account for the burnup varying both in plane $(X, Y)$ and axially $(Z)$.

\subsection{PRESSURIZED WATER REACTORS}

The PWR SNF analyzed and source reference documentation are presented in Table 2-1.

Table 2-1. PWR Plants for SNF Analyzed

\begin{tabular}{|c|c|}
\hline Plant & Reference \\
\hline Calvert Cliffs & CRWMS M\&O 1997a \\
\hline H.B. Robinson & CRWMS M\&O 1997c \\
\hline Mihama & CRWMS M\&O 1997d \\
\hline Obrigheim & CRWMS M\&O 1997e \\
\hline Trino Vercelles & CRWMS M\&O 1997f \\
\hline Turkey Point & CRWMS M\&O 1997g \\
\hline Yankee Rowe & CRWMS M\&O 1997h \\
\hline
\end{tabular}


Due to the fact that the reference information for the above plants contains detailed tables for the values used as input to the calculations, that information will not be duplicated in this report. What follows is a general description of the fuel for each reactor plant, the location of the fuel pins under consideration, and key assumptions regarding the calculations for a particular plant. Generally, assumptions used in the SAS2H calculations were carried over to the GRCASMO3 calculations if they applied.

It was assumed that the information from the references listed in Table 2-1 is accurate. The rationale for this assumption is that the information from these references is used for comparison purposes of a 1-D depletion code and a 2-D depletion code. Furthermore, it is expected that changes to the reference information format will have no impact on the information taken from them.

\subsubsection{Calvert Cliffs}

Calvert Cliffs used 14x14 Combustion Engineering (CE) fuel as shown in Figures 2-1 through 2-3. FA BT03 had 160 fuel rods, while assemblies D047 and D101 had 176. The additional fuel rods present in the latter two assemblies is due to 12 poison rods $\left(\mathrm{B}_{4} \mathrm{C}-\mathrm{Al}_{2} \mathrm{O}_{3}\right)$ and 4 non-fuel stainless steel test rods containing dry gas in BT03. The density of the fuel was $10.054 \mathrm{~g} / \mathrm{cm}^{3}$ for FA BT03 and $10.018 \mathrm{~g} / \mathrm{cm}^{3}$ for FAs D047 and D101. The enrichment was $2.453 \mathrm{wt} \% \mathrm{U}-235$ for FA BT03, 3.038 wt\% U-235 for FA D047, and $2.72 \mathrm{wt} \% \mathrm{U}-235$ for D101. The clad material was Zircaloy-4. The fuel burnup ranged from 18.68 to $46.46 \mathrm{GWd} / \mathrm{mtU}$. The cooling time ranged from 1870 to 2447 days. The specific power ranged from 13.06 to $32.51 \mathrm{MW} / \mathrm{mtU}$. The average boron concentration in the moderator ranged from $330.8 \mathrm{ppm}$ (cycle 1) to $503.7 \mathrm{ppm}$ (cycle 4).

The following assumption applied to Calvert Cliffs calculations:

- It was assumed that since the boron concentration in cycle 1 was not available, it was the same as that for cycle 2 . The rationale for this assumption is that boron concentration does not vary significantly from cycle to cycle. 


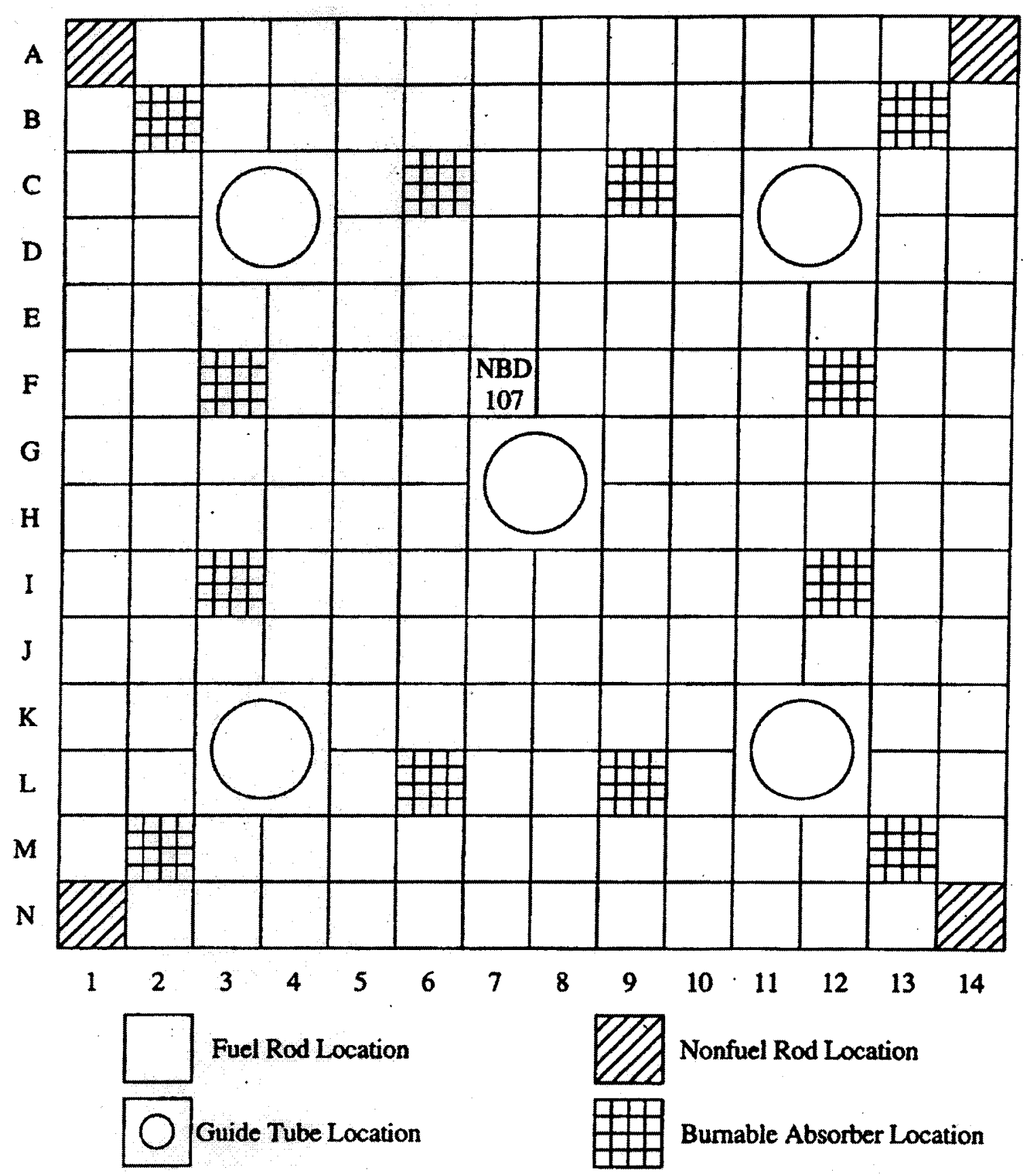

Figure 2-1. Location of Fuel Rod NBD107 in FA BT03 


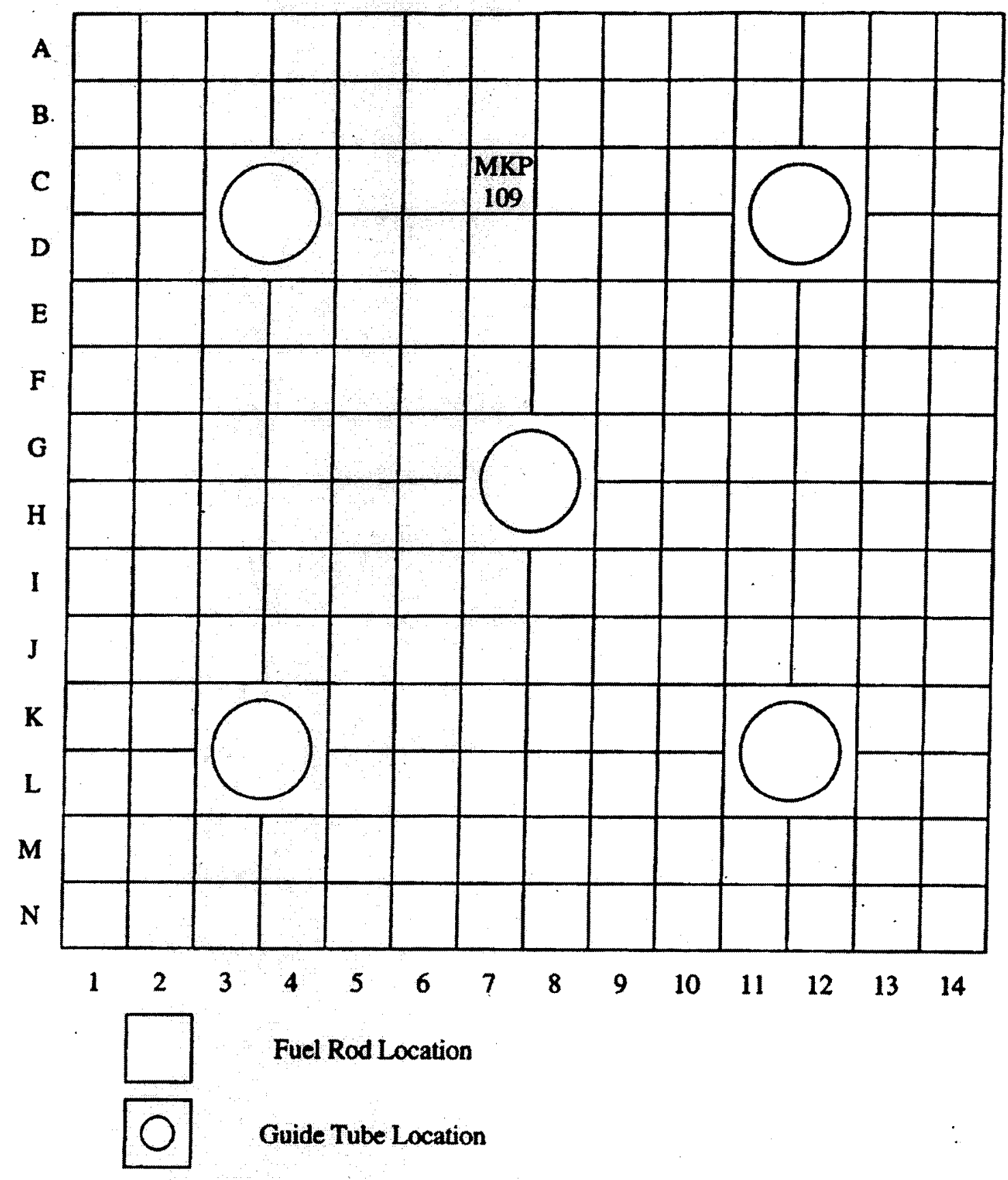

Figure 2-2. Location of Fuel Rod MKP109 in FA D047 


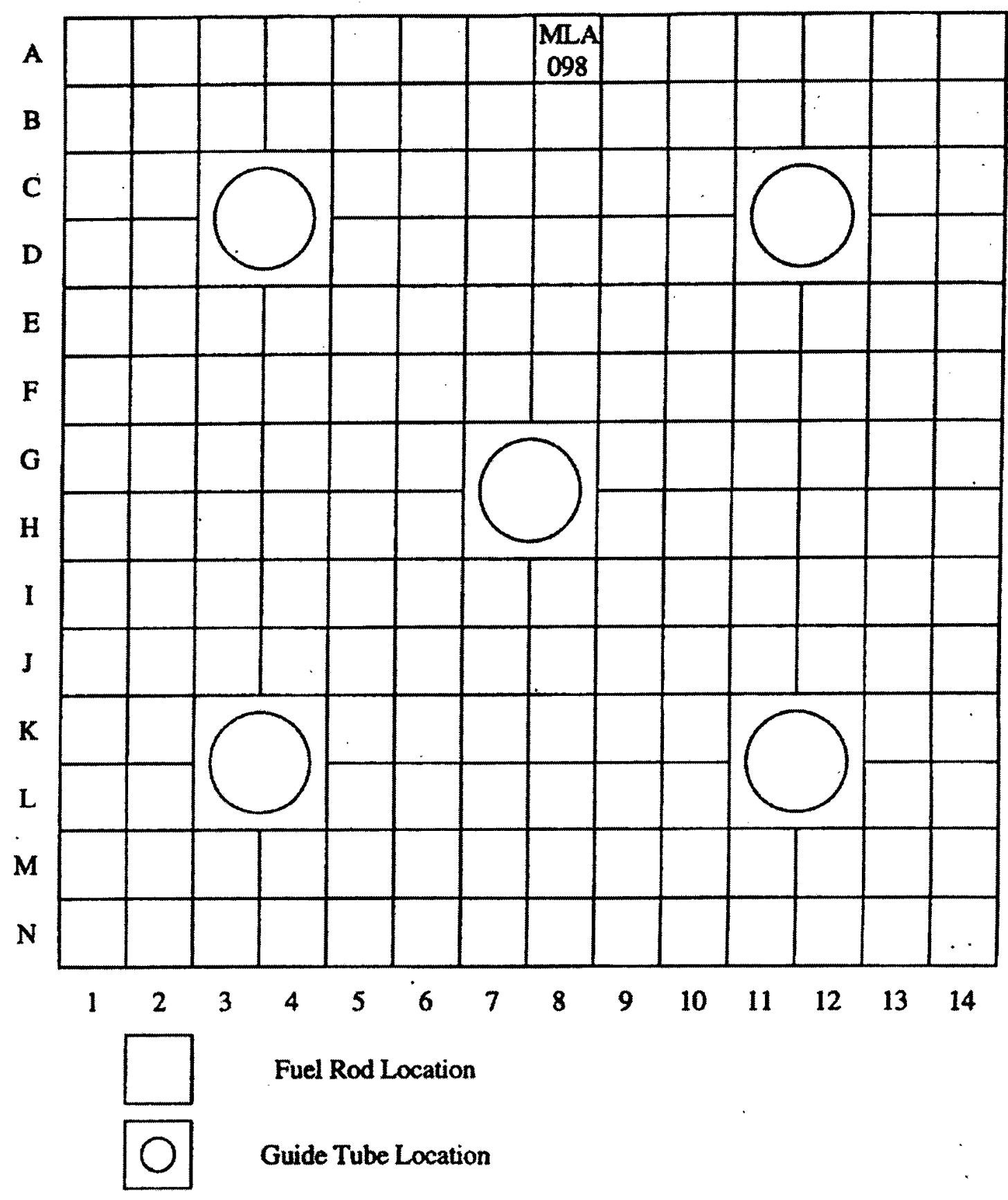

Figure 2-3. Location of Fuel Rod MLA098 in FA D101 


\subsubsection{H.B. Robinson}

H.B. Robinson used 15x15 Westinghouse (W) fuel comprising 204 fuel rods, 20 guide tubes, and one instrument tube as shown in Figure 2-4. Twelve of the guide tubes held burnable poison rods during cycle 1 . Rod N-9 from assembly B05 was sampled at four axial locations $-11 \mathrm{~cm}$, $26 \mathrm{~cm}, 199 \mathrm{~cm}$, and $226 \mathrm{~cm}$. The density of the fuel was $9.944 \mathrm{~g} / \mathrm{cm}^{3}$ and the enrichment was $2.561 \mathrm{wt} \% \mathrm{U}-235$. The clad material was Zircaloy-4. The fuel burnup ranged from 16.02 to $31.66 \mathrm{GWd} / \mathrm{mtU}$. The cooling time ranged from 3631 to 3936 days. The specific power ranged from 18.11 to $44.68 \mathrm{MW} / \mathrm{mtU}$. The average boron concentration in the moderator ranged from $652.2 \mathrm{ppm}$ (cycle $1,1^{\text {st }}$ interval) to $247.5 \mathrm{ppm}$ (cycle 2).

The following assumption applied to H.B. Robinson calculations:

- It was assumed that since the fuel temperatures were not available for H.B. Robinson, they were the same as those listed for Turkey Point Unit 3. The rationale for this assumption is that the relationship between power and temperature for H.B. Robinson and Turkey Point are similar since both use the same assembly design type. 


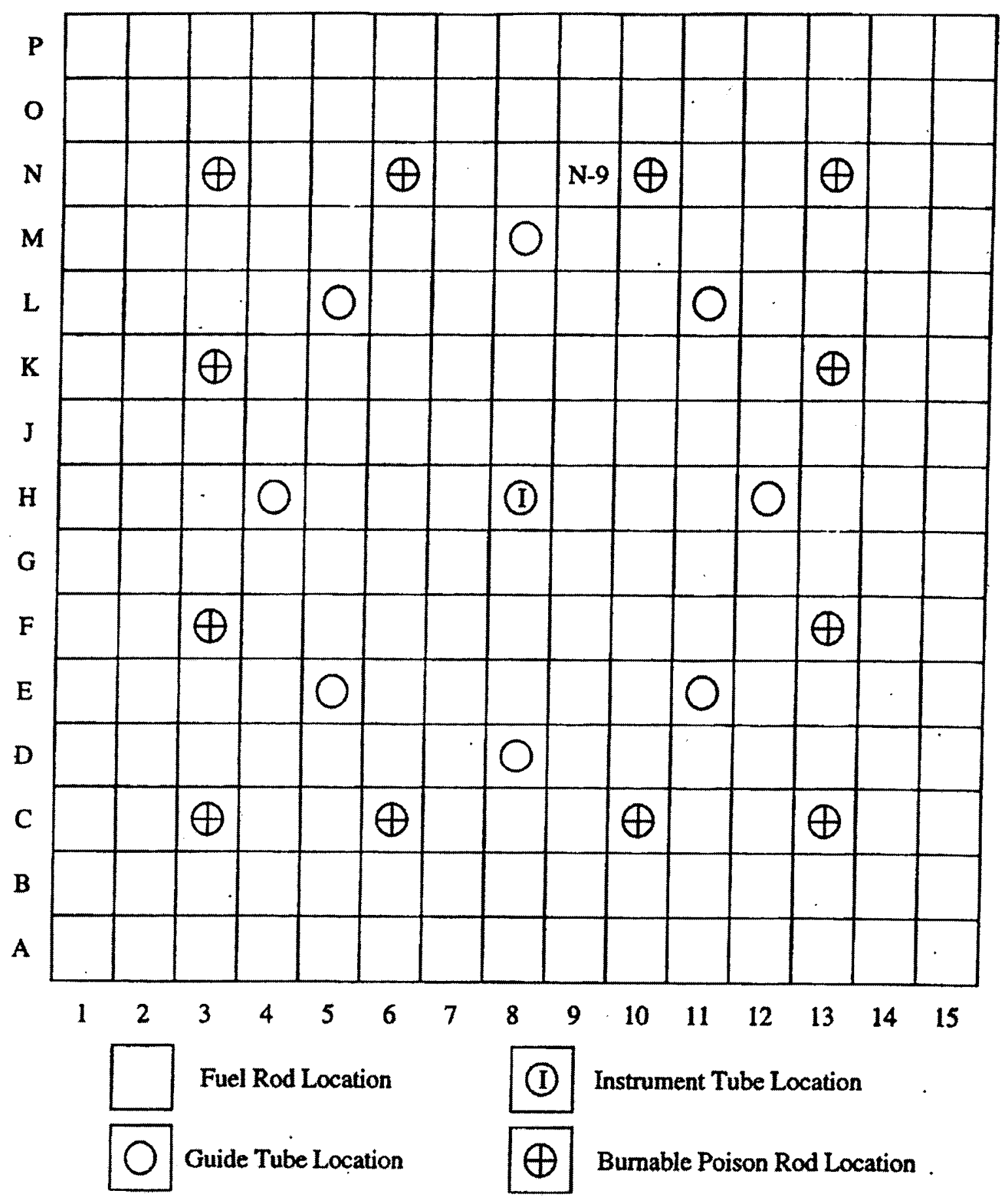

Figure 2-4. Cross Section of the H.B. Robinson Fuel Assembly 


\subsubsection{Obrigheim}

The Obrigheim plant used $14 \times 14$ Siemens fuel comprising 180 fuel rods and 16 guide tubes as shown in Figure 2-5. The Obrigheim sample data is different from the other samples in this report. The fuel assemblies were taken from this reactor and split into two halves lengthwise, with each half being dissolved separately from which the sample measurements were made. The other samples evaluated in this report typically come from a small section of a single fuel rod within an assembly. The density of the fuel was $10.05 \mathrm{~g} / \mathrm{cm}^{3}$ and the enrichment was $3.13 \mathrm{wt} \%$ U-235. The clad material was Zircaloy-4. The fuel burnup ranged from 25.93 to 29.52 $\mathrm{GWd} / \mathrm{mtU}$. The cooling time was 10 days. The specific power ranged from 20.929 to 38.952 $\mathrm{MW} / \mathrm{mtU}$. The average boron concentration in the moderator used for the calculations was 450 ppm (all cycles).

The following assumptions applied to Obrigheim calculations:

- Since the cooling time after shutdown was unknown, it was assumed to be 10 days. The rationale for this assumption is that a longer decay period (20 to 50 days) would not significantly effect the isotopic composition; however, a shorter decay period would effect isotopes that come in part from the decay of short lived parent isotopes (Dehart and Hermann 1996, pp. 7 through 10).

- Since the guide tube dimensions were not specified, guide tube dimensions from a $14 \times 14 \mathrm{~W}$ assembly were used. The rationale for this assumption is that the Obrigheim assembly is of similar design, and Siemens was a W licensee.

- Since the initial enrichments of U-234 and U-236 were not known, it assumed that they could be accurately approximated according to the following expressions:

$$
\begin{aligned}
& \text { U-234 wt } \%=0.0089 * U-235 w t \% \\
& \text { U-236 wt } \%=0.0046 * U-235 w t \%
\end{aligned}
$$

The rationale for this assumption is that these expressions provide typical U-234 and U-236 initial enrichments, and was used in Hermann et. al. (1995, p. 31).

- Since the assemblies were irradiated for a total of three cycles during cycles 3,4 , and 6 , and not loaded during cycle 5, it was assumed that summing the zero load days from each of the three operating cycles and using that as a total down time subsequent to irradiation in cycle 6 was adequate. Consequently, the sum of the full load days for a particular cycle was used as that cycle's burn time. The rationale for this assumption is that approximating the cycle length by summing the full load days will not significantly alter the isotopic concentrations because the relative number of zero load days to full load days is small. 


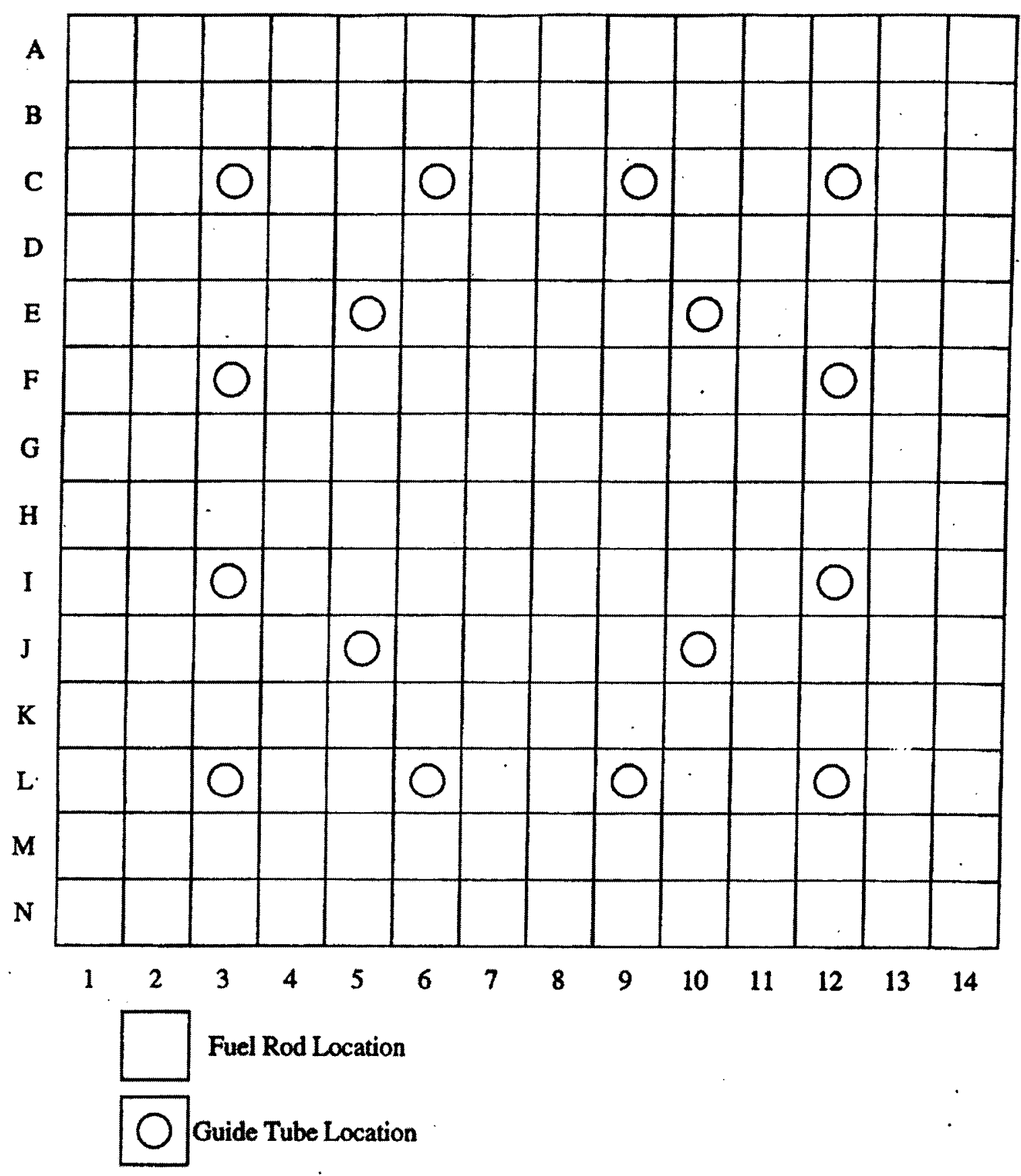

Figure 2-5. Cross Section of the Obrigheim Fuel Assembly 


\subsubsection{Mihama}

The Mihama PWR used 15x15 W fuel assemblies comprising 204 fuel rods, 20 guide tubes, and one instrument tube as shown in Figure 2-6. Nine samples were analyzed for Mihama. However, since the information on the pin location and axial location of these samples were incomplete, fuel assembly average isotopic concentrations were used for the comparisons. The density of the fuel was $9.996 \mathrm{~g} / \mathrm{cm}^{3}$ and the enrichment was $3.208 \mathrm{wt} \%$ U-235 for FA $86 \mathrm{~b}, 3.203$ wt\% U-235 for FA 86g, and 3.21 wt\% U-235 for FA 87c. The clad material was Zircaloy-4. The fuel burnup ranged from 6.92 to $34.32 \mathrm{GWd} / \mathrm{mtU}$. The cooling time was 1825 days. The specific power ranged from 22 to $44.1 \mathrm{MW} / \mathrm{mtU}$. The average boron concentration in the moderator used for the calculations was $450 \mathrm{ppm}$ (all cycles).

The following assumptions apply to Mihama calculations:

- It was assumed that since the fuel temperatures were not available for Mihama, they were the same as those listed for Turkey Point Unit 3. The rationale for this assumption is that the relationship between power and temperature for Mihama and Turkey Point are similar since both use the same assembly design type.

- An average boron concentration in the moderator of $450 \mathrm{ppm}$ was assumed for all cycles in the absence of detailed information. The rationale for this assumption is that this was a typical cycle average boron concentration for PWRs. 


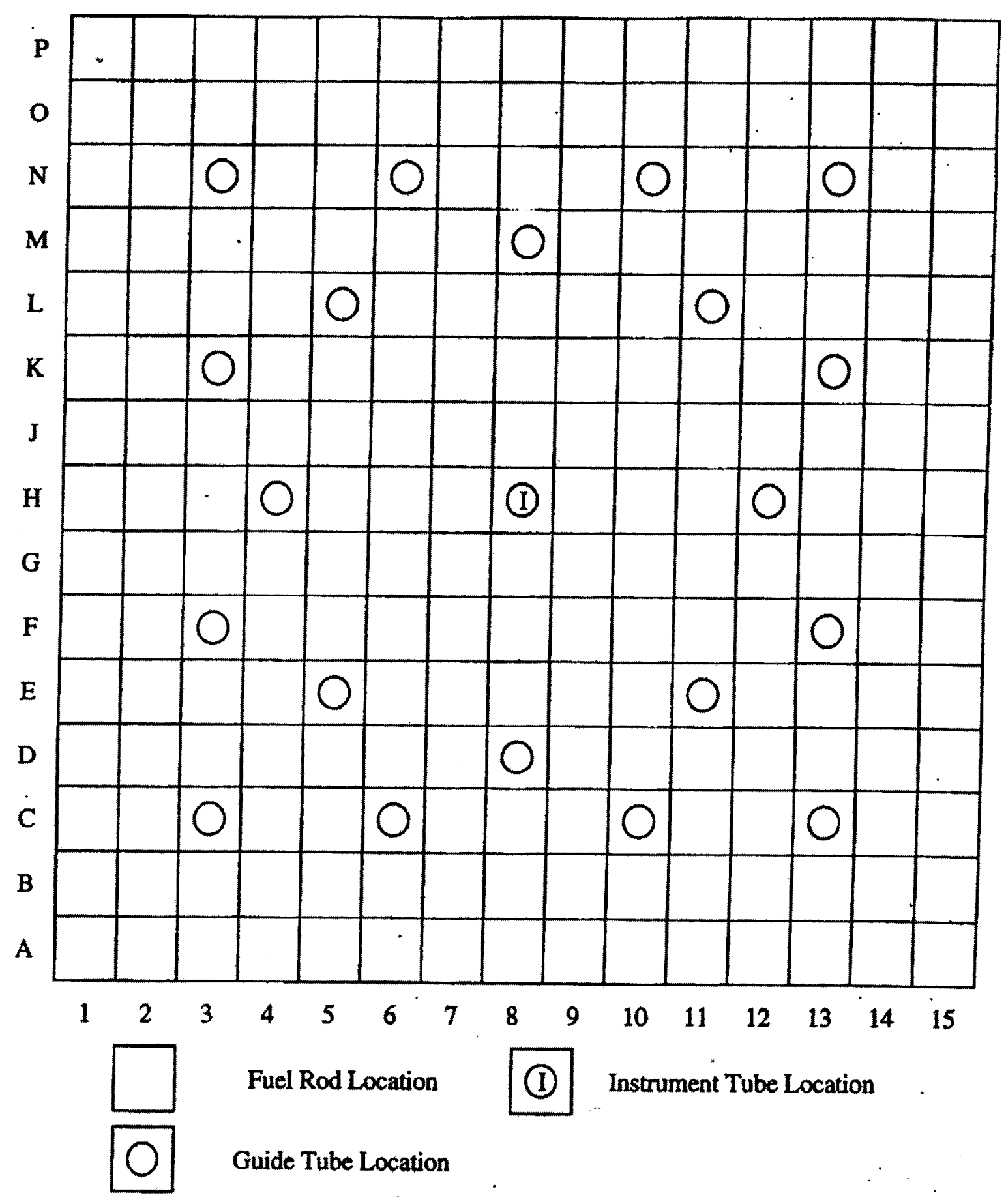

Figure 2-6. Cross Section of the Mihama Fuel Assembly 


\subsubsection{Trino Vercelles}

Trino Vercelles assemblies are non-typical PWR fuel assemblies. The core design uses two different types of fuel assemblies. The first is a $15 \times 15 \mathrm{~W}$ design comprising 208 fuel rods and one inner hole with 16 outer perimeter fuel cells removed so that the second, cruciform shaped assembly design may fit in between the square shaped assemblies. A cross-sectional view of the square and cruciform assemblies as they fit together is illustrated in Figure 2-7. Figures 2-8 through 2-10 show the locations of the fuel rods sampled for assemblies 509-032, 509-069, and 509-104. The density of the fuel was $10.079 \mathrm{~g} / \mathrm{cm}^{3}$ and the enrichment was $3.13 \mathrm{wt} \% \mathrm{U}-235$ for FA 509-032 and FA 509-069, while FA 509-104 was 3.87 wt\% U-235. The clad material was stainless steel-304. The fuel burnup ranged from 11.529 to $24.548 \mathrm{GWd} / \mathrm{mtU}$. The cooling time was 10 days. The specific power ranged from 7.148 to $24.639 \mathrm{MW} / \mathrm{mtU}$. The average boron concentrations in the moderator ranged from $1175 \mathrm{ppm}$ (cycle 1, period I) to $325 \mathrm{ppm}$ (cycle 1, period III).

The following assumptions apply to Trino Vercelles calculations:

- Since the cooling time after shutdown was unknown, it was assumed to be 10 days. The rationale for this assumption is that a longer decay period (20 to 50 days) would not significantly effect the isotopic composition; however, a shorter decay period would effect isotopes that come in part from the decay of short lived parent isotopes (Dehart and Hermann 1996, pp. 7 through 10).

- It was assumed for the GRCASMO3 calculations that the moderator temperature values from CRWMS M\&O (1997f, Table 4-7) under the column Cycle 1 was for cycle 1 and under column Cycles 1 and 2 was for cycle 2. The rationale for this assumption is that cycle 1 values are provided therefore using the moderator temperature value under the column Cycles 1 and 2 would be representative of the actual cycle 2 temperature.

- It was assumed for the GRCASMO3 calculations that the internally calculated moderator density based on temperature and pressure is sufficiently similar to the values reported in CRWMS M\&O (1997f, Table 4-7). The rationale for this assumption is that GRCASMO3 is a commercially used code for simulating reactor operating history conditions. 

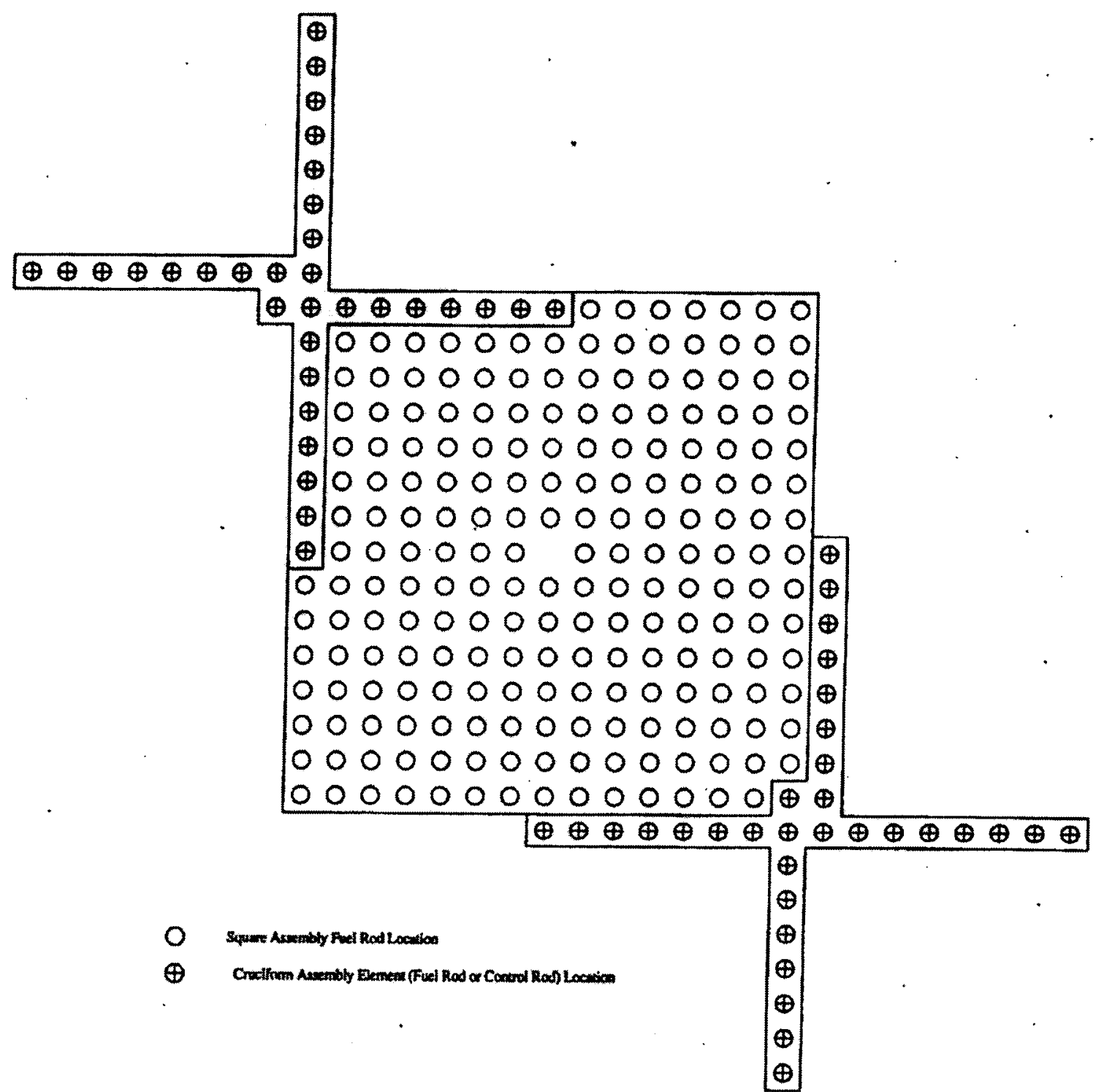

Figure 2-7. Cross Section of the Square and Cruciform Assemblies for Trino Vercelles 


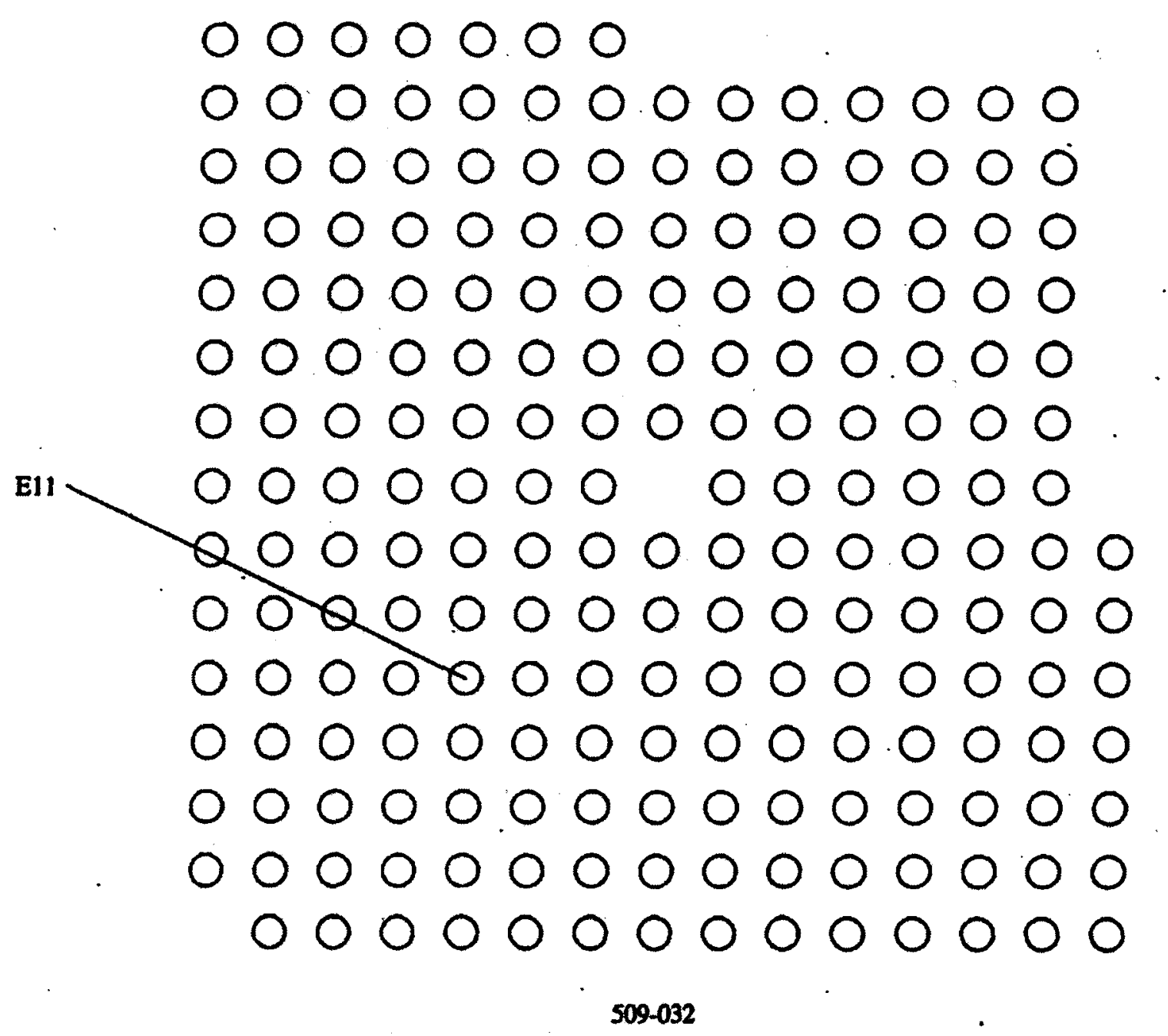

Figure 2-8. Fuel Rod Location for Trino Vercelles Assembly 509-032 


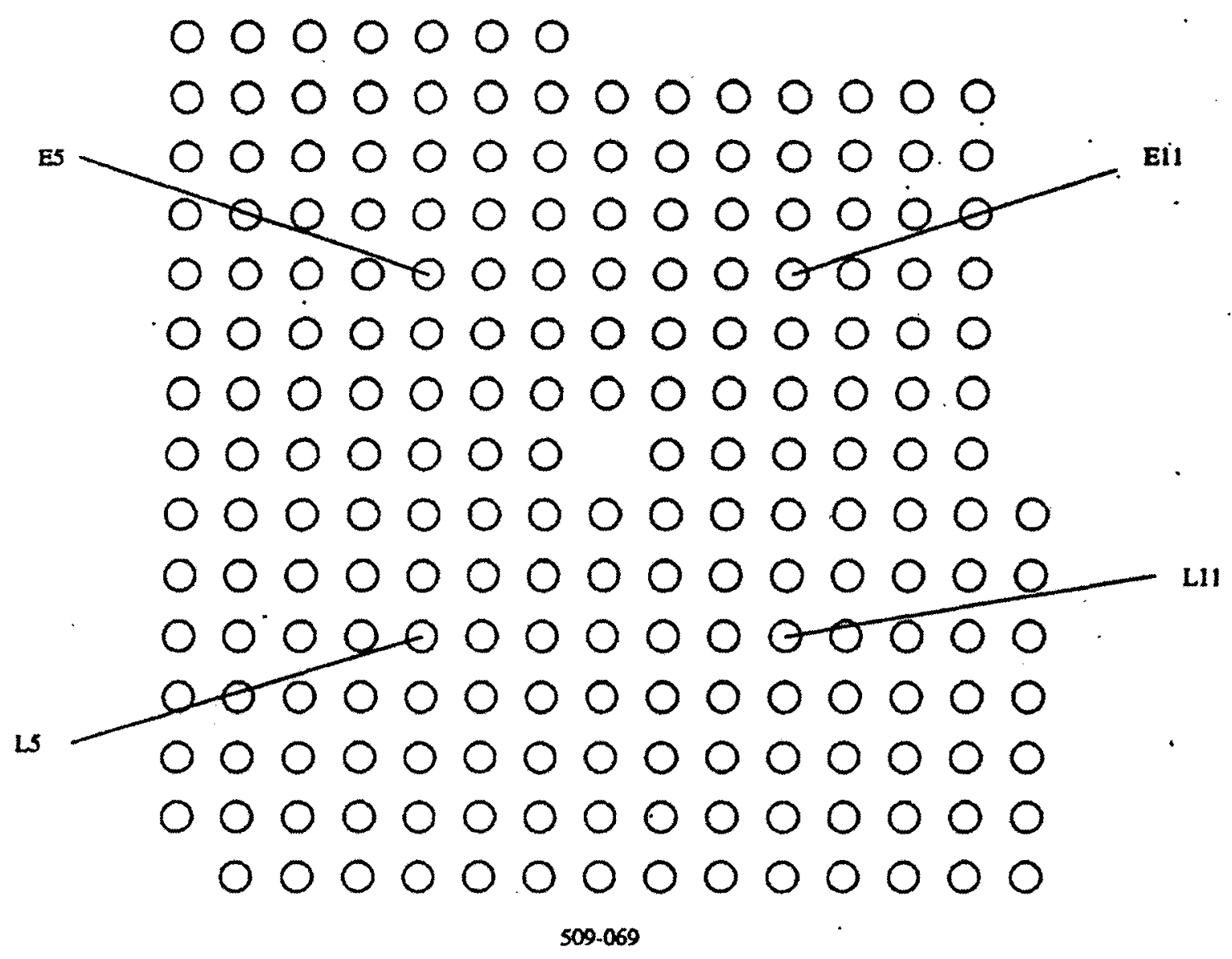

Figure 2-9. Fuel Rod Location for Trino Vercelles Assembly 509-069 


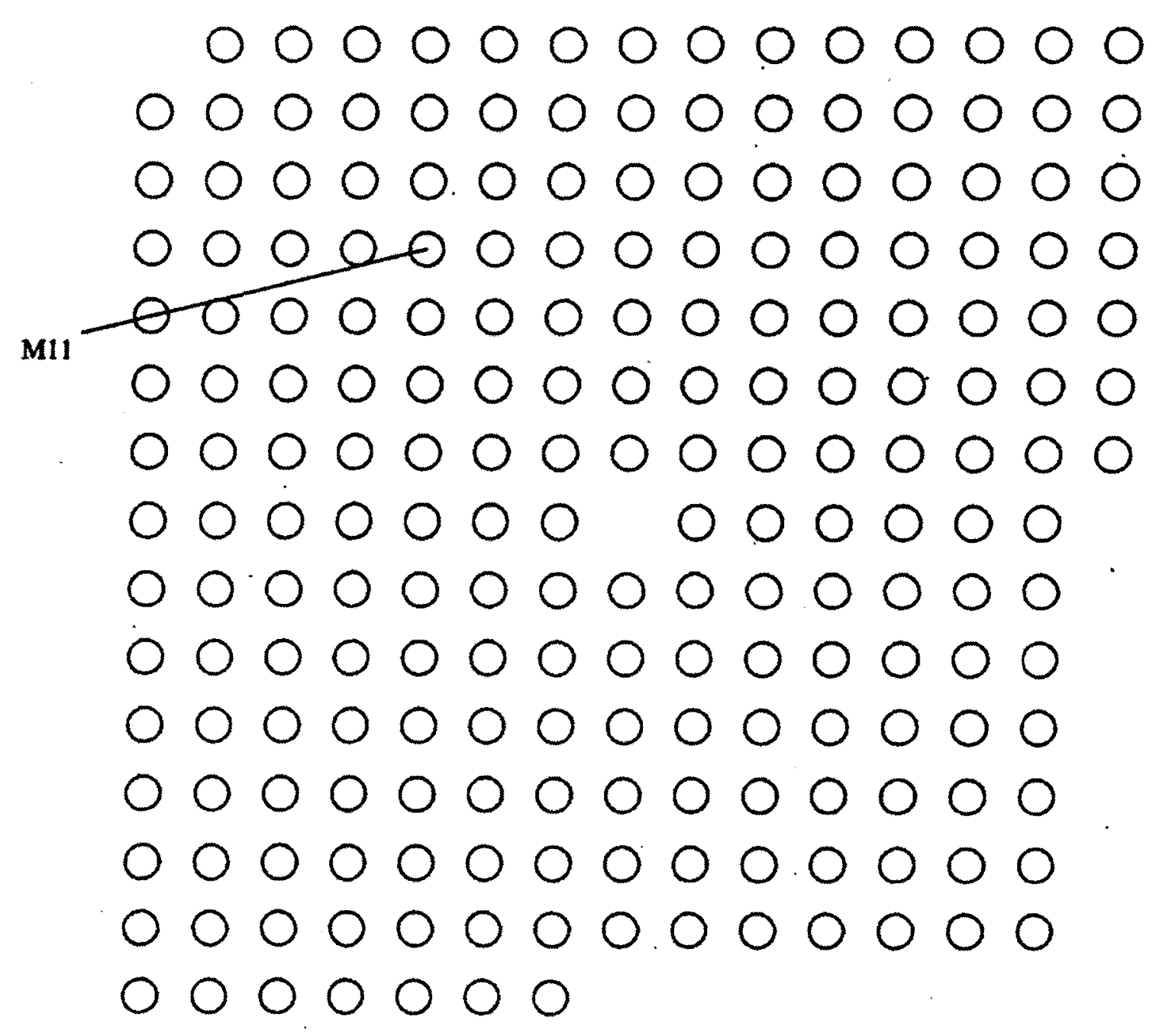

$509-104$

Figure 2-10. Fuel Rod Location for Trino Vercelles Assembly 509-104 


\subsubsection{Yankee Rowe}

Yankee Rowe assemblies are non-typical PWR fuel assemblies. They are a W design arranged in a $17 \times 18$ configuration with control blades. They comprise of 305 fuel rods and one empty cell in the center for a flux wire thimble as shown in Figure 2-11. Eight samples from assembly E6 were analyzed (RCA). Rod C-f6 from assembly E6 was sampled at four axial locations - 17.02 $\mathrm{cm}, 57.66 \mathrm{~cm}, 138.94 \mathrm{~cm}$, and $220.22 \mathrm{~cm}$. Rod SE-c2 from assembly E6 was sampled at two axial locations $-57.66 \mathrm{~cm}$ and $138.94 \mathrm{~cm}$. Rod SE-e4 from assembly E6 was also sampled at two axial locations $-57.66 \mathrm{~cm}$ and $138.94 \mathrm{~cm}$. The density of the fuel was $10.18 \mathrm{~g} / \mathrm{cm}^{3}$ and the enrichment was $3.4 \mathrm{wt} \% \mathrm{U}-235$. The clad material was stainless steel-348. The fuel burnup ranged from 15.95 to $35.97 \mathrm{GWd} / \mathrm{mtU}$. The cooling time was 281.5 days for all samples except E6-C-f6, (axial location $138.94 \mathrm{~cm}$ ) which was 717 days. The specific power ranged from 13.00 to $36.44 \mathrm{MW} / \mathrm{mtU}$. The average boron concentration in the moderator was $261 \mathrm{ppm}$ during cycle 4 .

The following assumptions apply to Yankee Rowe calculations:

- It was assumed that the wire thimble was not present in the empty center cell. The rationale for this assumption is that only 22/76 assemblies were equipped with a thimble, and the thimble material composition was not available.

- It was assumed that the control blades were not inserted in the vicinity of the sampled fuel assembly during cycles 1,2 , or 4 . The rationale for this assumption is that accurate information about the control blade composition and movement history were not available.

- It was assumed that the effects of the zircaloy shims, which occupied some of the outer ring of the control blade positions during each cycle were not significant. The rationale for this assumption is that although the placement of the assembly in cycle 1 is unknown, the placement during cycles 2 and 4 was in the center of the core where the effects of the zircaloy shims would be negligible. 




Figure 2-11. Fuel Rod Location for Yankee Rowe Assembly E6

\subsubsection{Turkey Point}

Turkey Point used $15 \times 15 \mathrm{~W}$ fuel comprising 204 fuel rods, 20 guide tubes, and one instrument tube as shown in Figure 2-12. The guide tubes and instrument tube were empty (containing only moderator) during operation. Samples analyzed were taken from two assemblies, D01 (three) and D04 (two). An axial location of $167 \mathrm{~cm}$ was used for D01-G10, D01-H09, and D04-G10, while an axial location of $167.6 \mathrm{~cm}$ was used for D01-G09 and D04-G09. The density of the fuel was $10.235 \mathrm{~g} / \mathrm{cm}^{3}$ and the enrichment was $2.556 \mathrm{wt} \% \mathrm{U}-235$. The clad material was Zircaloy-4. The fuel burnup ranged from 30.51 to $31.56 \mathrm{GWd} / \mathrm{mtU}$. The cooling time was 927 days. The specific power ranged from 32.015 to $33.116 \mathrm{MW} / \mathrm{mtU}$. The average boron concentration in the moderator used for the calculations was $450 \mathrm{ppm}$ (all cycles).

The following assumption applies to Turkey Point calculations: 
- Since cycle specific data for specific power was not available, it was assumed that using the average specific power based on total irradiation time and final burnup was acceptable. The rationale for this assumption is that the effect of specific power variation between cycles would have a small effect on the isotopic compositions.

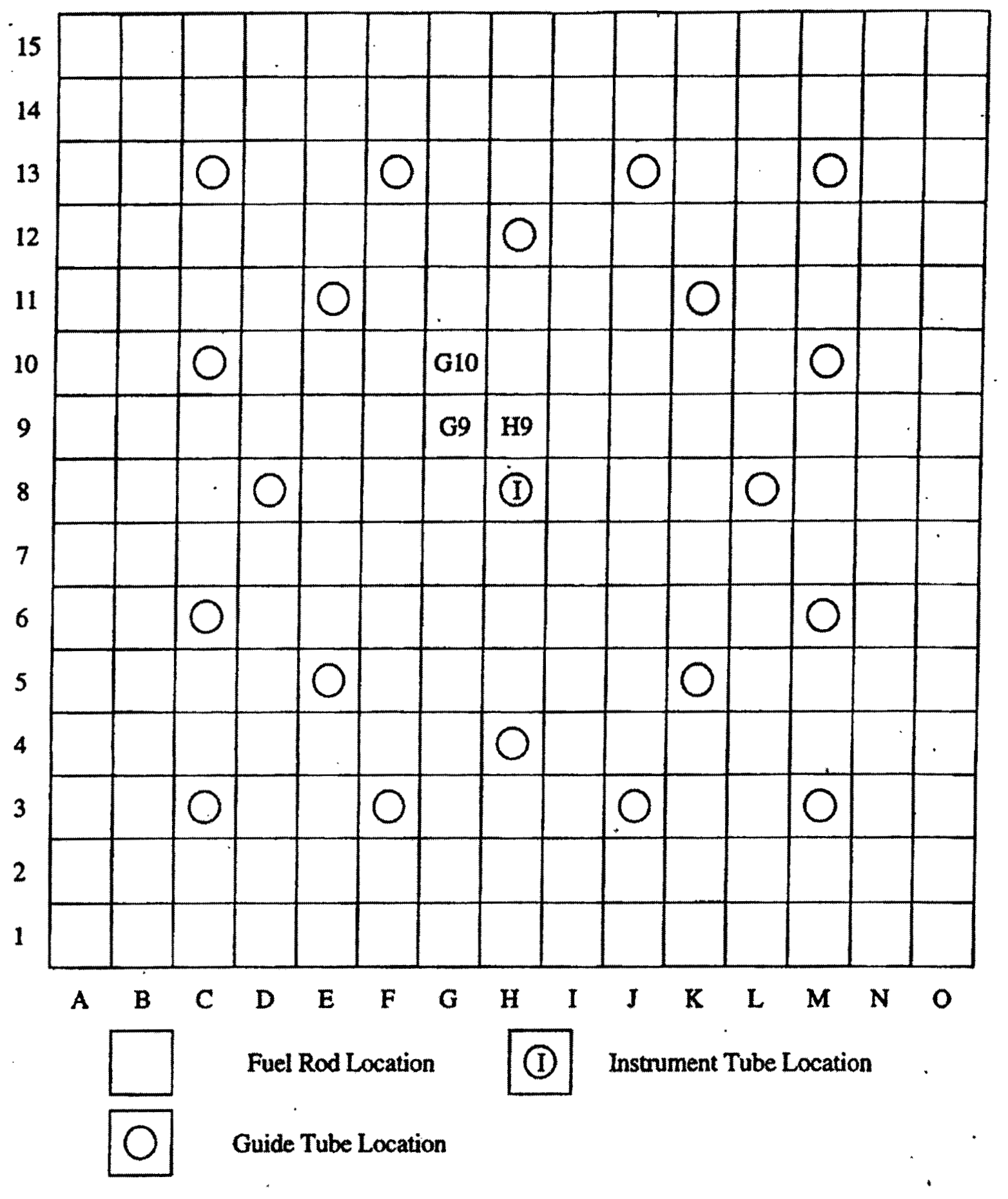

Figure 2-12. Cross Section of the Turkey Point Fuel Assembly 


\subsection{BOILING WATER REACTORS}

Due to the fact that the reference information (CRWMS M\&O 1997b) contains detailed tables for the values used as input to the calculations, that information will not be duplicated in this report. What follows is a general description of the fuel, the location of the fuel pins under consideration, and key assumptions regarding the calculations.

It was assumed that the information from CRWMS M\&O (1997b) is accurate. The rationale for this assumption is that the information is used for comparison purposes of a 1-D depletion code and a 2-D depletion code. Furthermore, it is expected that changes to the reference information format will have no impact on the information taken.

\subsubsection{Cooper}

Cooper used $7 \times 7$ General Electric (GE) fuel assemblies comprising 49 fuel rods as shown in Figure 2-13. Rods ADD2966 and ADD2974 were pulled from bundle CZ346. ADD2966 was sampled at three axial locations - $55.107 \mathrm{~cm}(\mathrm{~B}), 218.869 \mathrm{~cm}(\mathrm{~K})$, and $274.777 \mathrm{~cm}(\mathrm{~T})$. ADD2974 was sampled at three axial locations $-55.723 \mathrm{~cm}(\mathrm{~B}), 115.042 \mathrm{~cm}(\mathrm{~J})$, and 291.087 $\mathrm{cm}(\mathrm{U})$. The density of the fuel was $10.32 \mathrm{~g} / \mathrm{cm}^{3}$ and the enrichment was $2.93 \mathrm{wt} \% \mathrm{U}-235$. The clad material was Zircaloy-2. The fuel burnup ranged from 17.84 to $33.94 \mathrm{GWd} / \mathrm{mtU}$. The cooling time for ADD2966 was 5.35 years and for ADD2974 5.28 years. The specific power ranged from 4.38 to $27.01 \mathrm{MW} / \mathrm{mtU}$.

The following assumptions apply to Cooper calculations:

- Since average fuel temperatures were not available, it was assumed that $840 \mathrm{~K}$ was acceptable. The rationale for this assumption is that $840 \mathrm{~K}$ is a typical fuel temperature for BWRs.

- Since the moderator temperature was not available, it was assumed that $557 \mathrm{~K}$ was acceptable. The rationale for this assumption is that $557 \mathrm{~K}$ is a typical moderator temperature for BWRs.

- Since the moderator density profile was not available, it was assumed to be an inverse exponential function with an entrance density of $0.862 \mathrm{~g} / \mathrm{cm}^{3}$ with a plateau density of 0.24 $\mathrm{g} / \mathrm{cm}^{3}$. 


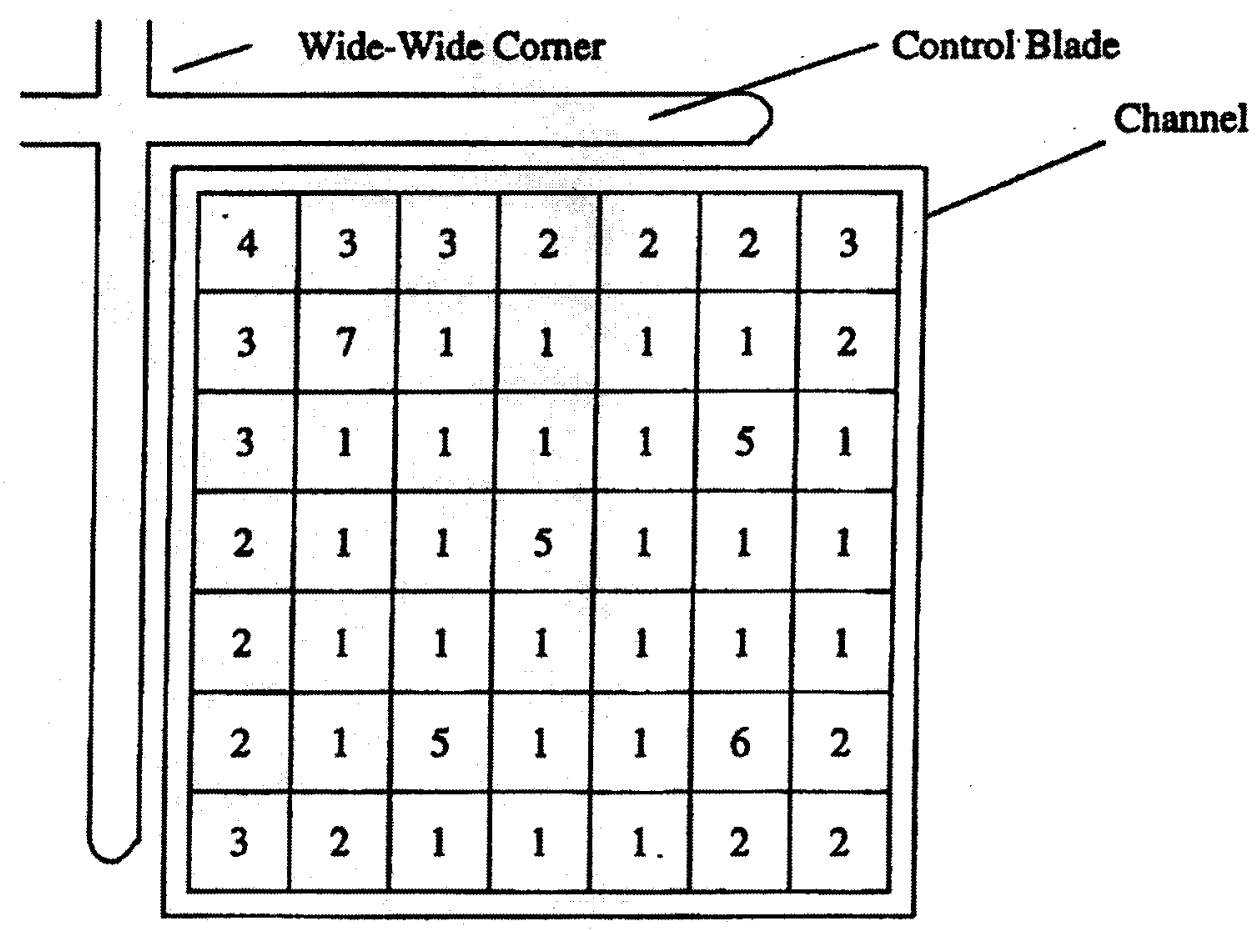

Fuel Rod Location

Figure 2-13. Cross Section of the Control Blade and Fuel Assembly for Cooper 


\section{RESULTS}

Throughout the following section, the measured and SAS2H values were taken from CRWMS M\&O (1997a) through CRWMS M\&O (1997h). The GRCASMO3 results were taken from DTN: MO0110SPARAD04.009. Each of the calculated and measured values are reported in units of $\mathrm{g} / \mathrm{mtUO}_{2}$.

\subsection{PRESSURIZED WATER REACTORS}

Results are presented for the following seven PWR plants:

- Calvert Cliffs

- H. B. Robinson

- Mihama

- Obrigheim

- Trino Vercelles

- Turkey Point

- Yankee Rowe.

A summary of results for the depletion of all seven PWRs considering the isotopic information on U-235, U-238, and Pu-239 is provided in Appendix A.

\subsubsection{Calvert Cliffs}

Tables 3-1 through 3-9 contain the results from the RCAs, the SAS2H calculations, and the GRCASMO3 calculations. The results are presented in both density and percent difference between the calculations (SAS2H and GRCASMO3) and the measured (RCA). Figures 3-1 through 3-3 are plots of the top three contributors to reactivity, U235, U238, and Pu239 for all nine samples from the Calvert Cliffs plant.

Table 3-1. Calvert Cliffs BT03, NBD107 $\left(A L^{a}=11.28 \mathrm{~cm}\right.$, Burnup $=31.4 \mathrm{GWd} / \mathrm{mtU}$ )

\begin{tabular}{|c|c|c|c|c|c|}
\hline Isotopes & Measured & SAS2H & GRCASMO3 & $\begin{array}{c}\text { GRCASMO3 \% } \\
\text { Difference }\end{array}$ & $\begin{array}{c}\text { SAS2H \% } \\
\text { Difference }\end{array}$ \\
\hline$U-234$ & $1.53 \mathrm{E}+02$ & $1.18 \mathrm{E}+02$ & $1.11 \mathrm{E}+02$ & -27.77 & -22.88 \\
\hline $\mathrm{U}-235$ & $3.86 \mathrm{E}+03$ & $4.66 \mathrm{E}+03$ & $3.63 \mathrm{E}+03$ & -6.04 & 20.73 \\
\hline $\mathrm{U}-236$ & $2.86 \mathrm{E}+03$ & $2.91 \mathrm{E}+03$ & $2.92 \mathrm{E}+03$ & 1.94 & 1.75 \\
\hline $\mathrm{U}-238$ & $8.45 \mathrm{E}+05$ & $8.37 \mathrm{E}+05$ & $8.39 \mathrm{E}+05$ & 0.69 & -0.90 \\
\hline $\mathrm{Np}-237$ & $2.62 \mathrm{E}+02$ & $3.10 \mathrm{E}+02$ & $2.97 \mathrm{E}+02$ & 13.29 & 18.32 \\
\hline $\mathrm{Pu}-238$ & $1.43 \mathrm{E}+02$ & $1.48 \mathrm{E}+02$ & $1.29 \mathrm{E}+02$ & 9.38 & 3.79 \\
\hline $\mathrm{Pu}-239$ & $3.81 \mathrm{E}+03$ & $3.52 \mathrm{E}+03$ & $3.63 \mathrm{E}+03$ & -4.70 & -7.71 \\
\hline $\mathrm{Pu}-240$ & $2.07 \mathrm{E}+03$ & $2.26 \mathrm{E}+03$ & $2.01 \mathrm{E}+03$ & -2.55 & 9.34 \\
\hline $\mathrm{Pu}-241$ & $7.26 \mathrm{E}+02$ & $7.23 \mathrm{E}+02$ & $5.85 \mathrm{E}+02$ & -19.37 & -0.41 \\
\hline $\mathrm{Pu}-242$ & $5.46 \mathrm{E}+02$ & $5.73 \mathrm{E}+02$ & $4.77 \mathrm{E}+02$ & -12.64 & 4.89 \\
\hline $\mathrm{Am}-241$ & $3.45 \mathrm{E}+02$ & $3.47 \mathrm{E}+02$ & $3.91 \mathrm{E}+02$ & 13.30 & 0.58 \\
\hline
\end{tabular}

NOTE: ${ }^{a} A L=$ axial location from bottom of fuel 
Table 3-2. Calvert Cliffs BT03, NBD107 (AL $=19.92 \mathrm{~cm}$, Burnup $=37.24 \mathrm{GWd} / \mathrm{mtU}$ )

\begin{tabular}{|c|c|c|c|c|c|}
\hline Isotopes & Measured & SAS2H & GRCASMO3 & $\begin{array}{c}\text { GRCASMO3 } \% \\
\text { Difference }\end{array}$ & $\begin{array}{c}\text { SAS2H \% } \\
\text { Difference }\end{array}$ \\
\hline$U-234$ & $1.27 \mathrm{E}+02$ & $1.09 \mathrm{E}+02$ & $9.69 \mathrm{E}+01$ & -23.69 & -14.17 \\
\hline $\mathrm{U}-235$ & $2.71 \mathrm{E}+03$ & $3.29 \mathrm{E}+03$ & $2.36 \mathrm{E}+03$ & -12.74 & 21.40 \\
\hline $\mathrm{U}-236$ & $3.03 \mathrm{E}+03$ & $3.05 \mathrm{E}+03$ & $3.02 \mathrm{E}+03$ & -0.22 & 0.66 \\
\hline $\mathrm{U}-238$ & $8.44 \mathrm{E}+05$ & $8.33 \mathrm{E}+05$ & $8.34 \mathrm{E}+05$ & -1.17 & -1.28 \\
\hline $\mathrm{Np}-237$ & $3.21 \mathrm{E}+02$ & $3.67 \mathrm{E}+02$ & $3.57 \mathrm{E}+02$ & 11.13 & 14.33 \\
\hline $\mathrm{Pu}-238$ & $1.95 \mathrm{E}+02$ & $2.00 \mathrm{E}+02$ & $1.77 \mathrm{E}+02$ & -8.98 & 2.72 \\
\hline $\mathrm{Pu}-239$ & $3.84 \mathrm{E}+03$ & $3.38 \mathrm{E}+03$ & $3.63 \mathrm{E}+03$ & -5.44 & -11.86 \\
\hline $\mathrm{Pu}-240$ & $2.32 \mathrm{E}+03$ & $2.49 \mathrm{E}+03$ & $2.25 \mathrm{E}+03$ & -3.02 & 7.28 \\
\hline $\mathrm{Pu}-241$ & $8.13 \mathrm{E}+02$ & $7.95 \mathrm{E}+02$ & $6.51 \mathrm{E}+02$ & -19.93 & -2.21 \\
\hline $\mathrm{Pu}-242$ & $7.75 \mathrm{E}+02$ & $8.13 \mathrm{E}+02$ & $6.82 \mathrm{E}+02$ & -12.00 & 4.86 \\
\hline $\mathrm{Am}-241$ & $4.27 \mathrm{E}+02$ & $3.71 \mathrm{E}+02$ & $4.28 \mathrm{E}+02$ & 0.27 & -13.11 \\
\hline
\end{tabular}

Table 3-3. Calvert Cliffs BT03, NBD107 (AL $=161.21 \mathrm{~cm}$, Burnup $=46.46 \mathrm{GWd} / \mathrm{mtU}$ )

\begin{tabular}{|c|c|c|c|c|c|}
\hline Isotopes & Measured & SAS2H & GRCASMO3 & $\begin{array}{c}\text { GRCASMO3 \% } \\
\text { Difference }\end{array}$ & $\begin{array}{c}\text { SAS2H \% } \\
\text { Difference }\end{array}$ \\
\hline$U-234$ & $7.49 \mathrm{E}+01$ & $9.76 \mathrm{E}+01$ & $7.79 \mathrm{E}+01$ & 4.00 & 30.31 \\
\hline $\mathrm{U}-235$ & $1.41 \mathrm{E}+03$ & $1.95 \mathrm{E}+03$ & $1.23 \mathrm{E}+03$ & -12.36 & 38.69 \\
\hline $\mathrm{U}-236$ & $3.04 \mathrm{E}+03$ & $3.13 \mathrm{E}+03$ & $3.04 \mathrm{E}+03$ & 0.12 & 2.96 \\
\hline $\mathrm{U}-238$ & $8.27 \mathrm{E}+05$ & $8.25 \mathrm{E}+05$ & $8.26 \mathrm{E}+05$ & -0.19 & -0.27 \\
\hline $\mathrm{Np}-237$ & $3.78 \mathrm{E}+02$ & $4.48 \mathrm{E}+02$ & $4.39 \mathrm{E}+02$ & 16.24 & 18.52 \\
\hline $\mathrm{Pu}-238$ & $2.84 \mathrm{E}+02$ & $2.90 \mathrm{E}+02$ & $2.55 \mathrm{E}+02$ & -10.42 & 2.04 \\
\hline $\mathrm{Pu}-239$ & $3.77 \mathrm{E}+03$ & $3.32 \mathrm{E}+03$ & $3.66 \mathrm{E}+03$ & -2.83 & -11.84 \\
\hline $\mathrm{Pu}-240$ & $2.60 \mathrm{E}+03$ & $2.75 \mathrm{E}+03$ & $2.52 \mathrm{E}+03$ & -2.88 & 5.81 \\
\hline $\mathrm{Pu}-241$ & $8.86 \mathrm{E}+02$ & $8.82 \mathrm{E}+02$ & $7.32 \mathrm{E}+02$ & -17.44 & -0.47 \\
\hline $\mathrm{Pu}-242$ & $1.17 \mathrm{E}+03$ & $1.21 \mathrm{E}+03$ & $1.01 \mathrm{E}+03$ & -13.54 & 3.51 \\
\hline Am-241 & $6.37 \mathrm{E}+02$ & $3.96 \mathrm{E}+02$ & $4.71 \mathrm{E}+02$ & -26.07 & -37.83 \\
\hline
\end{tabular}

Table 3-4. Calvert Cliffs D047, MKP109 (AL $=13.2 \mathrm{~cm}$, Burnup $=27.35 \mathrm{GWd} / \mathrm{mtU}$ )

\begin{tabular}{|c|c|c|c|c|c|}
\hline Isotopes & Measured & SAS2H & GRCASMO3 & $\begin{array}{c}\text { GRCASMO3 \% } \\
\text { Difference }\end{array}$ & $\begin{array}{c}\text { SAS2H \% } \\
\text { Difference }\end{array}$ \\
\hline$U-234$ & $1.60 \mathrm{E}+02$ & $1.59 \mathrm{E}+02$ & $1.54 \mathrm{E}+02$ & -3.95 & -0.62 \\
\hline $\mathrm{U}-235$ & $8.47 \mathrm{E}+03$ & $8.33 \mathrm{E}+03$ & $8.35 \mathrm{E}+03$ & -1.37 & -1.65 \\
\hline $\mathrm{U}-236$ & $3.14 \mathrm{E}+03$ & $3.23 \mathrm{E}+03$ & $3.21 \mathrm{E}+03$ & 2.30 & 2.87 \\
\hline $\mathrm{U}-238$ & $8.43 \mathrm{E}+05$ & $8.37 \mathrm{E}+05$ & $8.37 \mathrm{E}+05$ & -0.61 & -0.65 \\
\hline $\mathrm{Np}-237$ & $2.68 \mathrm{E}+02$ & $2.78 \mathrm{E}+02$ & $2.90 \mathrm{E}+02$ & 8.31 & 3.73 \\
\hline $\mathrm{Pu}-238$ & $1.01 \mathrm{E}+02$ & $9.56 \mathrm{E}+01$ & $9.61 \mathrm{E}+01$ & -4.82 & -5.35 \\
\hline $\mathrm{Pu}-239$ & $4.26 \mathrm{E}+03$ & $3.67 \mathrm{E}+03$ & $4.29 \mathrm{E}+03$ & 0.51 & -13.93 \\
\hline $\mathrm{Pu}-240$ & $1.72 \mathrm{E}+03$ & $1.80 \mathrm{E}+03$ & $1.71 \mathrm{E}+03$ & -0.41 & 4.71 \\
\hline $\mathrm{Pu}-241$ & $6.81 \mathrm{E}+02$ & $6.66 \mathrm{E}+02$ & $5.88 \mathrm{E}+02$ & -13.66 & -2.20 \\
\hline $\mathrm{Pu}-242$ & $2.89 \mathrm{E}+02$ & $3.37 \mathrm{E}+02$ & $2.61 \mathrm{E}+02$ & -9.65 & 16.61 \\
\hline $\mathrm{Am}-241$ & $2.50 \mathrm{E}+02$ & $2.37 \mathrm{E}+02$ & $3.19 \mathrm{E}+02$ & 27.73 & -5.20 \\
\hline
\end{tabular}

Table 3-5. Calvert Cliffs D047, MKP109 $(\mathrm{AL}=27.7 \mathrm{~cm}$, Burnup $=37.12 \mathrm{GWd} / \mathrm{mtU})$

\begin{tabular}{|c|c|c|c|c|c|}
\hline Isotopes & Measured & SAS2H & GRCASMO3 & $\begin{array}{c}\text { GRCASMO3 \% } \\
\text { Difference }\end{array}$ & $\begin{array}{c}\text { SAS2H \% } \\
\text { Difference }\end{array}$ \\
\hline $\mathrm{U}-234$ & $1.40 \mathrm{E}+02$ & $1.38 \mathrm{E}+02$ & $1.27 \mathrm{E}+02$ & -9.04 & -1.43 \\
\hline $\mathrm{U}-235$ & $5.17 \mathrm{E}+03$ & $5.06 \mathrm{E}+03$ & $5.01 \mathrm{E}+03$ & -3.06 & -2.13 \\
\hline $\mathrm{U}-236$ & $3.53 \mathrm{E}+03$ & $3.65 \mathrm{E}+03$ & $3.62 \mathrm{E}+03$ & 2.68 & 3.40 \\
\hline $\mathrm{U}-238$ & $8.33 \mathrm{E}+05$ & $8.30 \mathrm{E}+05$ & $8.30 \mathrm{E}+05$ & -0.32 & -0.32 \\
\hline $\mathrm{Np}-237$ & $3.56 \mathrm{E}+02$ & $4.00 \mathrm{E}+02$ & $4.19 \mathrm{E}+02$ & 17.72 & 12.36 \\
\hline $\mathrm{Pu}-238$ & $1.89 \mathrm{E}+02$ & $1.83 \mathrm{E}+02$ & $1.84 \mathrm{E}+02$ & -2.77 & -3.17 \\
\hline
\end{tabular}


Table 3-5. Calvert Cliffs D047, MKP109 (AL $=27.7 \mathrm{~cm}$, Burnup $=37.12 \mathrm{GWd} / \mathrm{mtU}$ )

\begin{tabular}{|c|c|c|c|c|c|}
\hline Isotopes & Measured & SAS2H & GRCASMO3 & $\begin{array}{c}\text { GRCASMO3 \% } \\
\text { Difference }\end{array}$ & $\begin{array}{c}\text { SAS2H \% } \\
\text { Difference }\end{array}$ \\
\hline $\mathrm{Pu}-239$ & $4.36 \mathrm{E}+03$ & $3.71 \mathrm{E}+03$ & $4.34 \mathrm{E}+03$ & -0.33 & -14.85 \\
\hline $\mathrm{Pu}-240$ & $2.24 \mathrm{E}+03$ & $2.28 \mathrm{E}+03$ & $2.21 \mathrm{E}+03$ & -1.51 & 1.83 \\
\hline $\mathrm{Pu}-241$ & $9.03 \mathrm{E}+02$ & $8.51 \mathrm{E}+02$ & $7.77 \mathrm{E}+02$ & -13.96 & -5.76 \\
\hline $\mathrm{Pu}-242$ & $5.76 \mathrm{E}+02$ & $6.67 \mathrm{E}+02$ & $5.30 \mathrm{E}+02$ & -7.94 & 15.80 \\
\hline $\mathrm{Am}-241$ & $3.45 \mathrm{E}+02$ & $2.95 \mathrm{E}+02$ & $4.15 \mathrm{E}+02$ & 20.28 & -14.49 \\
\hline
\end{tabular}

Table 3-6. Calvert Cliffs D047, MKP109 (AL $=165.22 \mathrm{~cm}$, Burnup $=44.34 \mathrm{GWd} / \mathrm{mtU})$

\begin{tabular}{|c|c|c|c|c|c|}
\hline Isotopes & Measured & SAS2H & GRCASMO3 & $\begin{array}{c}\text { GRCASMO3 } \\
\text { Difference }\end{array}$ & $\begin{array}{c}\text { SAS2H \% } \\
\text { Difference }\end{array}$ \\
\hline $\mathrm{U}-234$ & $1.20 \mathrm{E}+02$ & $1.22 \mathrm{E}+02$ & $1.09 \mathrm{E}+02$ & -9.03 & 1.67 \\
\hline $\mathrm{U}-235$ & $3.54 \mathrm{E}+03$ & $3.30 \mathrm{E}+03$ & $3.43 \mathrm{E}+03$ & -3.14 & -6.78 \\
\hline $\mathrm{U}-236$ & $3.69 \mathrm{E}+03$ & $3.75 \mathrm{E}+03$ & $3.76 \mathrm{E}+03$ & 1.96 & 1.63 \\
\hline $\mathrm{U}-238$ & $8.25 \mathrm{E}+05$ & $8.24 \mathrm{E}+05$ & $8.24 \mathrm{E}+05$ & -0.10 & -0.10 \\
\hline $\mathrm{Np}-237$ & $4.68 \mathrm{E}+02$ & $5.01 \mathrm{E}+02$ & $5.12 \mathrm{E}+02$ & 9.34 & 7.05 \\
\hline $\mathrm{Pu}-238$ & $2.69 \mathrm{E}+02$ & $2.48 \mathrm{E}+02$ & $2.63 \mathrm{E}+02$ & -2.31 & -7.81 \\
\hline $\mathrm{Pu}-239$ & $4.36 \mathrm{E}+03$ & $4.52 \mathrm{E}+03$ & $4.39 \mathrm{E}+03$ & 0.87 & 3.74 \\
\hline $\mathrm{Pu}-240$ & $2.54 \mathrm{E}+03$ & $2.53 \mathrm{E}+03$ & $2.49 \mathrm{E}+03$ & -2.21 & -0.51 \\
\hline $\mathrm{Pu}-241$ & $1.02 \mathrm{E}+03$ & $9.95 \mathrm{E}+02$ & $8.87 \mathrm{E}+02$ & -13.02 & -2.45 \\
\hline $\mathrm{Pu}-242$ & $8.40 \mathrm{E}+02$ & $8.44 \mathrm{E}+02$ & $7.60 \mathrm{E}+02$ & -9.56 & 0.48 \\
\hline $\mathrm{Am}-241$ & $3.83 \mathrm{E}+02$ & $3.42 \mathrm{E}+02$ & $4.67 \mathrm{E}+02$ & 22.06 & -10.70 \\
\hline
\end{tabular}

Table 3-7. Calvert Cliffs D101, MLA098 (AL $=8.9 \mathrm{~cm}$, Burnup $=18.68 \mathrm{GWd} / \mathrm{mtU})$

\begin{tabular}{|c|c|c|c|c|c|}
\hline Isotopes & Measured & SAS2H & GRCASMO3 & $\begin{array}{c}\text { GRCASMO3 \% } \\
\text { Difference }\end{array}$ & $\begin{array}{c}\text { SAS2H \% } \\
\text { Difference }\end{array}$ \\
\hline $\mathrm{U}-234$ & $1.40 \mathrm{E}+02$ & $1.58 \mathrm{E}+02$ & $1.56 \mathrm{E}+02$ & 11.69 & 12.86 \\
\hline $\mathrm{U}-235$ & $1.03 \mathrm{E}+04$ & $1.03 \mathrm{E}+04$ & $1.03 \mathrm{E}+04$ & 0.89 & 0.49 \\
\hline $\mathrm{U}-236$ & $2.50 \mathrm{E}+03$ & $2.44 \mathrm{E}+03$ & $2.43 \mathrm{E}+03$ & -2.63 & -2.40 \\
\hline $\mathrm{U}-238$ & $8.55 \mathrm{E}+05$ & $8.46 \mathrm{E}+05$ & $8.45 \mathrm{E}+05$ & -1.12 & -1.06 \\
\hline $\mathrm{Np}-237$ & $1.75 \mathrm{E}+02$ & $1.67 \mathrm{E}+02$ & $1.73 \mathrm{E}+02$ & -1.11 & -4.57 \\
\hline $\mathrm{Pu}-238$ & $4.85 \mathrm{E}+01$ & $3.81 \mathrm{E}+01$ & $3.84 \mathrm{E}+01$ & -20.87 & -21.44 \\
\hline $\mathrm{Pu}-239$ & $3.95 \mathrm{E}+03$ & $3.38 \mathrm{E}+03$ & $3.91 \mathrm{E}+03$ & -1.03 & -14.52 \\
\hline $\mathrm{Pu}-240$ & $1.24 \mathrm{E}+03$ & $1.32 \mathrm{E}+03$ & $1.22 \mathrm{E}+03$ & -1.51 & 6.19 \\
\hline $\mathrm{Pu}-241$ & $4.54 \mathrm{E}+02$ & $4.25 \mathrm{E}+02$ & $3.63 \mathrm{E}+02$ & -20.15 & -6.45 \\
\hline $\mathrm{Pu}-242$ & $1.39 \mathrm{E}+02$ & $1.50 \mathrm{E}+02$ & $1.16 \mathrm{E}+02$ & -16.83 & 7.60 \\
\hline Am-241 & $1.95 \mathrm{E}+02$ & $1.80 \mathrm{E}+02$ & $2.26 \mathrm{E}+02$ & 15.96 & -7.69 \\
\hline
\end{tabular}

Table 3-8. Calvert Cliffs D101, MLA098 (AL $=24.3 \mathrm{~cm}$, Burnup $=26.62 \mathrm{GWd} / \mathrm{mtU})$

\begin{tabular}{|c|c|c|c|c|c|}
\hline Isotopes & Measured & SAS2H & GRCASMO3 & $\begin{array}{c}\text { GRCASMO3 \% } \\
\text { Difference }\end{array}$ & $\begin{array}{c}\text { SAS2H \% } \\
\text { Difference }\end{array}$ \\
\hline $\mathrm{U}-234$ & $1.21 \mathrm{E}+02$ & $1.40 \mathrm{E}+02$ & $1.35 \mathrm{E}+02$ & 11.61 & 15.70 \\
\hline $\mathrm{U}-235$ & $6.94 \mathrm{E}+03$ & $7.05 \mathrm{E}+03$ & $6.90 \mathrm{E}+03$ & -0.53 & 1.59 \\
\hline $\mathrm{U}-236$ & $2.99 \mathrm{E}+03$ & $2.93 \mathrm{E}+03$ & $2.93 \mathrm{E}+03$ & -1.86 & -2.01 \\
\hline $\mathrm{U}-238$ & $8.54 \mathrm{E}+05$ & $8.40 \mathrm{E}+05$ & $8.40 \mathrm{E}+05$ & -1.65 & -1.62 \\
\hline $\mathrm{Np}-237$ & $3.00 \mathrm{E}+02$ & $2.64 \mathrm{E}+02$ & $2.76 \mathrm{E}+02$ & -8.10 & -12.00 \\
\hline $\mathrm{Pu}-238$ & $9.69 \mathrm{E}+01$ & $8.88 \mathrm{E}+01$ & $8.68 \mathrm{E}+01$ & -10.44 & -8.36 \\
\hline $\mathrm{Pu}-239$ & $4.25 \mathrm{E}+03$ & $3.42 \mathrm{E}+03$ & $4.24 \mathrm{E}+03$ & -0.34 & -19.57 \\
\hline $\mathrm{Pu}-240$ & $1.77 \mathrm{E}+03$ & $1.89 \mathrm{E}+03$ & $1.75 \mathrm{E}+03$ & -0.67 & 7.02 \\
\hline $\mathrm{Pu}-241$ & $6.82 \mathrm{E}+02$ & $6.48 \mathrm{E}+02$ & $5.70 \mathrm{E}+02$ & -16.49 & -5.01 \\
\hline $\mathrm{Pu}-242$ & $3.30 \mathrm{E}+02$ & $3.74 \mathrm{E}+02$ & $2.89 \mathrm{E}+02$ & -12.57 & 13.30 \\
\hline $\mathrm{Am}-241$ & $2.90 \mathrm{E}+02$ & $2.71 \mathrm{E}+02$ & $3.52 \mathrm{E}+02$ & 21.52 & -6.55 \\
\hline
\end{tabular}


Table 3-9. Calvert Cliffs D101, MLA098 (AL $=161.7 \mathrm{~cm}$, Burnup $=33.17 \mathrm{GWd} / \mathrm{mtU}$ )

\begin{tabular}{|c|c|c|c|c|c|}
\hline Isotopes & Measured & SAS2H & GRCASMO3 & $\begin{array}{c}\text { GRCASMO3 } \% \\
\text { Difference }\end{array}$ & $\begin{array}{c}\text { SAS2H \% } \\
\text { Difference }\end{array}$ \\
\hline $\mathrm{U}-234$ & $1.20 \mathrm{E}+02$ & $1.28 \mathrm{E}+02$ & $1.18 \mathrm{E}+02$ & -1.43 & 6.67 \\
\hline $\mathrm{U}-235$ & $4.78 \mathrm{E}+03$ & $5.16 \mathrm{E}+03$ & $4.93 \mathrm{E}+03$ & 3.23 & 7.95 \\
\hline $\mathrm{U}-236$ & $3.26 \mathrm{E}+03$ & $3.18 \mathrm{E}+03$ & $3.18 \mathrm{E}+03$ & -2.34 & -2.45 \\
\hline $\mathrm{U}-238$ & $8.42 \mathrm{E}+05$ & $8.35 \mathrm{E}+05$ & $8.34 \mathrm{E}+05$ & -0.93 & -0.85 \\
\hline $\mathrm{Np}-237$ & $3.43 \mathrm{E}+02$ & $3.46 \mathrm{E}+02$ & $3.65 \mathrm{E}+02$ & 6.27 & 0.87 \\
\hline $\mathrm{Pu}-238$ & $1.48 \mathrm{E}+02$ & $1.48 \mathrm{E}+02$ & $1.42 \mathrm{E}+02$ & -4.20 & -0.20 \\
\hline $\mathrm{Pu}-239$ & $4.19 \mathrm{E}+03$ & $3.46 \mathrm{E}+03$ & $4.40 \mathrm{E}+03$ & 5.09 & -17.36 \\
\hline $\mathrm{Pu}-240$ & $2.11 \mathrm{E}+03$ & $2.25 \mathrm{E}+03$ & $2.12 \mathrm{E}+03$ & 0.46 & 6.58 \\
\hline $\mathrm{Pu}-241$ & $8.13 \mathrm{E}+02$ & $7.99 \mathrm{E}+02$ & $7.16 \mathrm{E}+02$ & -11.86 & -1.66 \\
\hline $\mathrm{Pu}-242$ & $5.47 \mathrm{E}+02$ & $6.16 \mathrm{E}+02$ & $4.79 \mathrm{E}+02$ & -12.42 & 12.53 \\
\hline $\mathrm{Am}-241$ & $3.51 \mathrm{E}+02$ & $3.30 \mathrm{E}+02$ & $4.41 \mathrm{E}+02$ & 25.51 & -5.98 \\
\hline
\end{tabular}

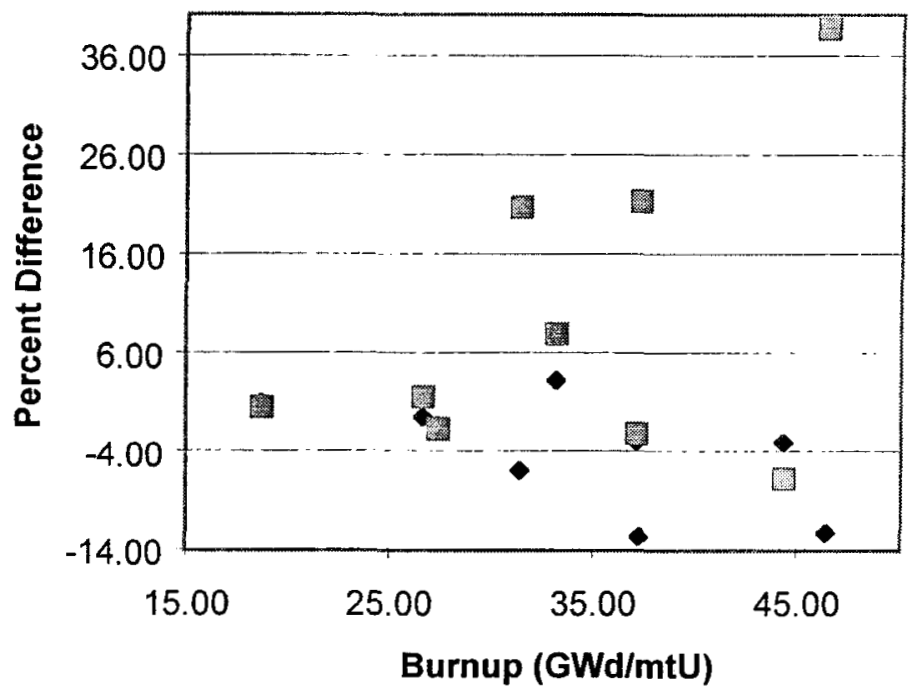

U-235 GRCASMO3

U U-235 SAS2H

Figure 3-1. Calvert Cliffs U-235 Comparison 


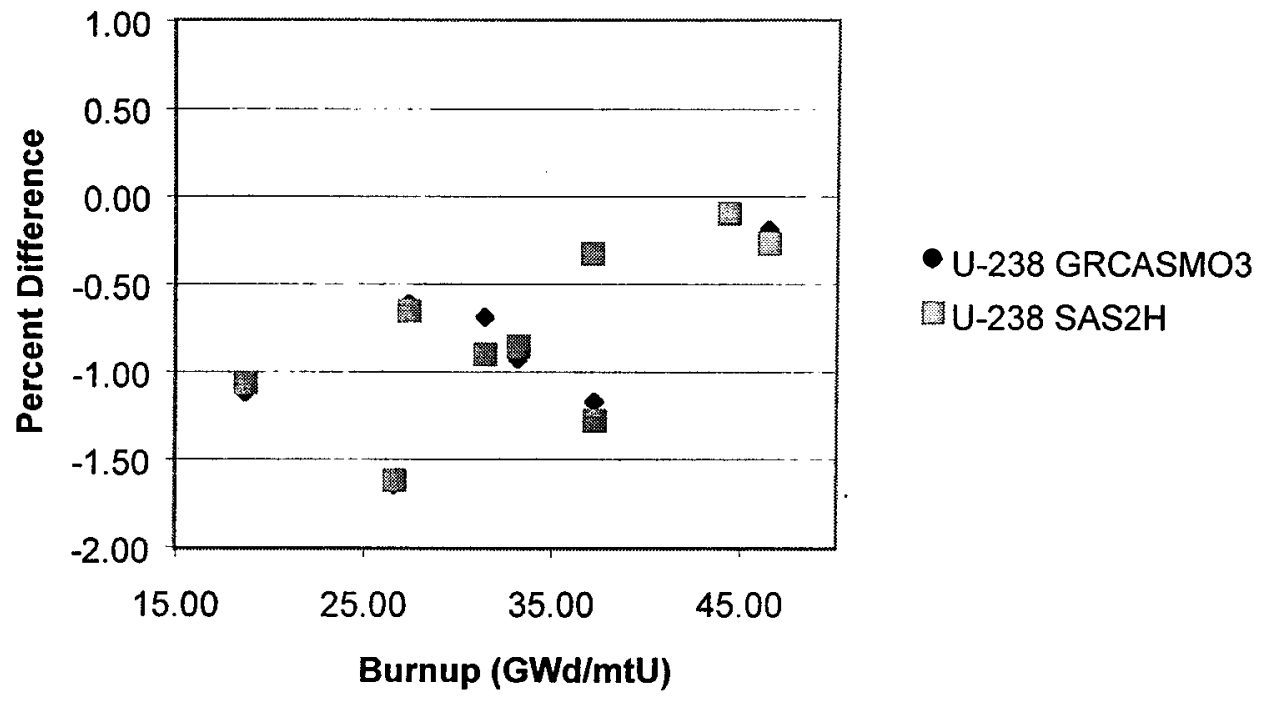

Figure 3-2. Calvert Cliffs U-238 Comparison

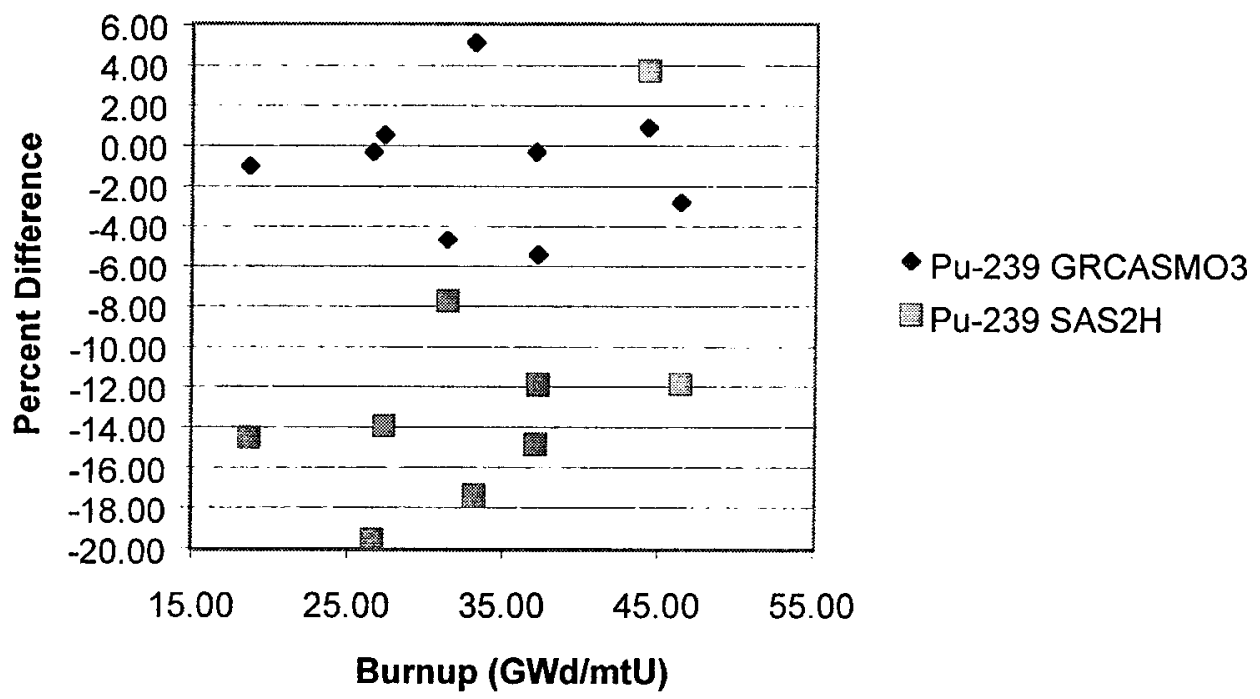

Figure 3-3. Calvert Cliffs Pu-239 Comparison

\subsubsection{H.B. Robinson}

Tables 3-10 through 3-13 contain the results from the RCAs, the SAS2H calculations, and the GRCASMO3 calculations. The results are presented in both density and percent difference between the calculations (SAS2H and GRCASMO3) and the measured (RCA). Figures 3-4 through 3-6 are plots of the top three contributors to reactivity, U235, U238, and Pu239 for all four samples from the H. B. Robinson plant. 
Table 3-10. H.B. Robinson PWR Sample N-9B-S ( $A L=11 \mathrm{~cm}$, Burnup $=16.02 \mathrm{GWd} / \mathrm{mtU}$ )

\begin{tabular}{|c|c|c|c|c|c|}
\hline Isotopes & Measured & SAS2H & GRCASMO3 & $\begin{array}{c}\text { GRCASMO3 \% } \\
\text { Difference }\end{array}$ & $\begin{array}{c}\text { SAS2H \% } \\
\text { Difference }\end{array}$ \\
\hline $\mathrm{U}-235$ & $1.07 \mathrm{E}+04$ & $1.11 \mathrm{E}+04$ & $1.09 \mathrm{E}+04$ & 1.86 & 3.74 \\
\hline $\mathrm{U}-236$ & $2.19 \mathrm{E}+03$ & $2.13 \mathrm{E}+03$ & $2.03 \mathrm{E}+03$ & -7.22 & -2.74 \\
\hline $\mathrm{U}-238$ & $8.47 \mathrm{E}+05$ & $8.47 \mathrm{E}+05$ & $8.48 \mathrm{E}+05$ & 0.13 & 0.00 \\
\hline $\mathrm{Np}-237$ & $1.55 \mathrm{E}+02$ & $1.49 \mathrm{E}+02$ & $1.34 \mathrm{E}+02$ & -13.40 & -3.87 \\
\hline $\mathrm{Pu}-238$ & $2.83 \mathrm{E}+01$ & $2.76 \mathrm{E}+01$ & $4.54 \mathrm{E}+01$ & 60.41 & -2.47 \\
\hline $\mathrm{Pu}-239$ & $3.64 \mathrm{E}+03$ & $4.02 \mathrm{E}+03$ & $3.81 \mathrm{E}+03$ & 4.68 & 10.44 \\
\hline $\mathrm{Pu}-240$ & $1.09 \mathrm{E}+03$ & $1.16 \mathrm{E}+03$ & $1.15 \mathrm{E}+03$ & 5.24 & 6.42 \\
\hline $\mathrm{Pu}-241$ & $3.04 \mathrm{E}+02$ & $3.14 \mathrm{E}+02$ & $2.38 \mathrm{E}+02$ & -21.67 & 3.29 \\
\hline
\end{tabular}

Table 3-11. H.B. Robinson PWR Sample N-9B-N (AL $=26 \mathrm{~cm}$, Burnup $=23.81 \mathrm{GWd} / \mathrm{mtU})$

\begin{tabular}{|c|c|c|c|c|c|}
\hline Isotopes & Measured & SAS2H & GRCASMO3 & $\begin{array}{c}\text { GRCASMO3 \% } \\
\text { Difference }\end{array}$ & $\begin{array}{c}\text { SAS2H } \% \\
\text { Difference }\end{array}$ \\
\hline $\mathrm{U}-235$ & $7.21 \mathrm{E}+03$ & $7.64 \mathrm{E}+03$ & $7.44 \mathrm{E}+03$ & 3.17 & 5.96 \\
\hline $\mathrm{U}-236$ & $2.74 \mathrm{E}+03$ & $2.66 \mathrm{E}+03$ & $2.57 \mathrm{E}+03$ & -6.23 & -2.92 \\
\hline $\mathrm{U}-238$ & $8.47 \mathrm{E}+05$ & $8.42 \mathrm{E}+05$ & $8.42 \mathrm{E}+05$ & -0.55 & -0.59 \\
\hline $\mathrm{Np}-237$ & $2.60 \mathrm{E}+02$ & $2.47 \mathrm{E}+02$ & $2.28 \mathrm{E}+02$ & -12.13 & -5.00 \\
\hline $\mathrm{Pu}-238$ & $6.95 \mathrm{E}+01$ & $6.62 \mathrm{E}+01$ & $1.17 \mathrm{E}+02$ & 68.27 & -4.75 \\
\hline $\mathrm{Pu}-239$ & $4.02 \mathrm{E}+03$ & $4.40 \mathrm{E}+03$ & $4.18 \mathrm{E}+03$ & 3.90 & 9.45 \\
\hline $\mathrm{Pu}-240$ & $1.67 \mathrm{E}+03$ & $1.73 \mathrm{E}+03$ & $1.73 \mathrm{E}+03$ & 3.31 & 3.59 \\
\hline $\mathrm{Pu}-241$ & $5.04 \mathrm{E}+02$ & $5.12 \mathrm{E}+02$ & $4.07 \mathrm{E}+02$ & -19.27 & 1.59 \\
\hline
\end{tabular}

Table 3-12. H.B. Robinson PWR Sample N-9C-J ( $A L=199 \mathrm{~cm}$, Burnup $=28.47 \mathrm{GWd} / \mathrm{mtU})$

\begin{tabular}{|c|c|c|c|c|c|}
\hline Isotopes & Measured & SAS2H & GRCASMO3 & $\begin{array}{c}\text { GRCASMO3 \% } \\
\text { Difference }\end{array}$ & $\begin{array}{c}\text { SAS2H \% } \\
\text { Difference }\end{array}$ \\
\hline $\mathrm{U}-235$ & $6.18 \mathrm{E}+03$ & $6.21 \mathrm{E}+03$ & $6.01 \mathrm{E}+03$ & -2.75 & 0.49 \\
\hline $\mathrm{U}-236$ & $2.82 \mathrm{E}+03$ & $2.88 \mathrm{E}+03$ & $2.78 \mathrm{E}+03$ & -1.27 & 2.13 \\
\hline $\mathrm{U}-238$ & $8.34 \mathrm{E}+05$ & $8.38 \mathrm{E}+05$ & $8.38 \mathrm{E}+05$ & 0.52 & 0.48 \\
\hline $\mathrm{Np}-237$ & $3.04 \mathrm{E}+02$ & $3.12 \mathrm{E}+02$ & $2.92 \mathrm{E}+02$ & -3.95 & 2.63 \\
\hline $\mathrm{Pu}-238$ & $1.14 \mathrm{E}+02$ & $1.00 \mathrm{E}+02$ & $1.79 \mathrm{E}+02$ & 57.00 & -12.28 \\
\hline $\mathrm{Pu}-239$ & $4.39 \mathrm{E}+03$ & $4.61 \mathrm{E}+03$ & $4.36 \mathrm{E}+03$ & -0.65 & 5.01 \\
\hline $\mathrm{Pu}-240$ & $1.97 \mathrm{E}+03$ & $2.03 \mathrm{E}+03$ & $2.04 \mathrm{E}+03$ & 3.71 & 3.05 \\
\hline $\mathrm{Pu}-241$ & $6.81 \mathrm{E}+02$ & $6.54 \mathrm{E}+02$ & $5.26 \mathrm{E}+02$ & -22.71 & -3.96 \\
\hline
\end{tabular}

Table 3-13. H.B. Robinson PWR Sample N-9C-D ( $\mathrm{AL}=226 \mathrm{~cm}$, Burnup $=31.66 \mathrm{GWd} / \mathrm{mtU})$

\begin{tabular}{|c|c|c|c|c|c|}
\hline Isotopes & Measured & SAS2H & GRCASMO3 & $\begin{array}{c}\text { GRCASMO3 \% } \\
\text { Difference }\end{array}$ & $\begin{array}{c}\text { SAS2H } \% \\
\text { Difference }\end{array}$ \\
\hline $\mathrm{U}-235$ & $4.86 \mathrm{E}+03$ & $5.32 \mathrm{E}+03$ & $5.14 \mathrm{E}+03$ & 5.75 & 9.47 \\
\hline $\mathrm{U}-236$ & $3.00 \mathrm{E}+03$ & $2.99 \mathrm{E}+03$ & $2.90 \mathrm{E}+03$ & -3.43 & -0.33 \\
\hline $\mathrm{U}-238$ & $8.42 \mathrm{E}+05$ & $8.35 \mathrm{E}+05$ & $8.36 \mathrm{E}+05$ & -0.75 & -0.83 \\
\hline $\mathrm{Np}-237$ & $3.33 \mathrm{E}+02$ & $3.54 \mathrm{E}+02$ & $3.32 \mathrm{E}+02$ & -0.27 & 6.31 \\
\hline $\mathrm{Pu}-238$ & $1.30 \mathrm{E}+02$ & $1.25 \mathrm{E}+02$ & $2.22 \mathrm{E}+02$ & 70.93 & -3.85 \\
\hline $\mathrm{Pu}-239$ & $4.20 \mathrm{E}+03$ & $4.68 \mathrm{E}+03$ & $4.42 \mathrm{E}+03$ & 5.23 & 11.43 \\
\hline $\mathrm{Pu}-240$ & $2.12 \mathrm{E}+03$ & $2.21 \mathrm{E}+03$ & $2.22 \mathrm{E}+03$ & 4.75 & 4.25 \\
\hline $\mathrm{Pu}-241$ & $6.92 \mathrm{E}+02$ & $7.18 \mathrm{E}+02$ & $5.82 \mathrm{E}+02$ & -15.92 & 3.76 \\
\hline
\end{tabular}




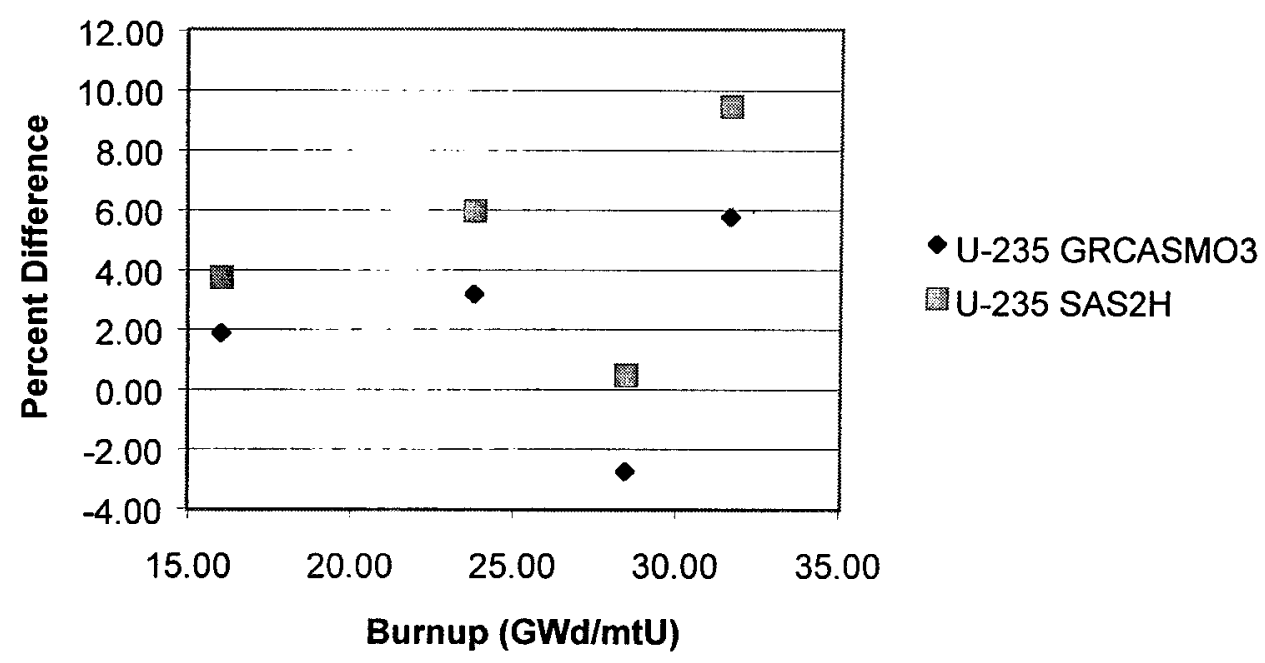

Figure 3-4. H.B. Robinson U-235 Comparison

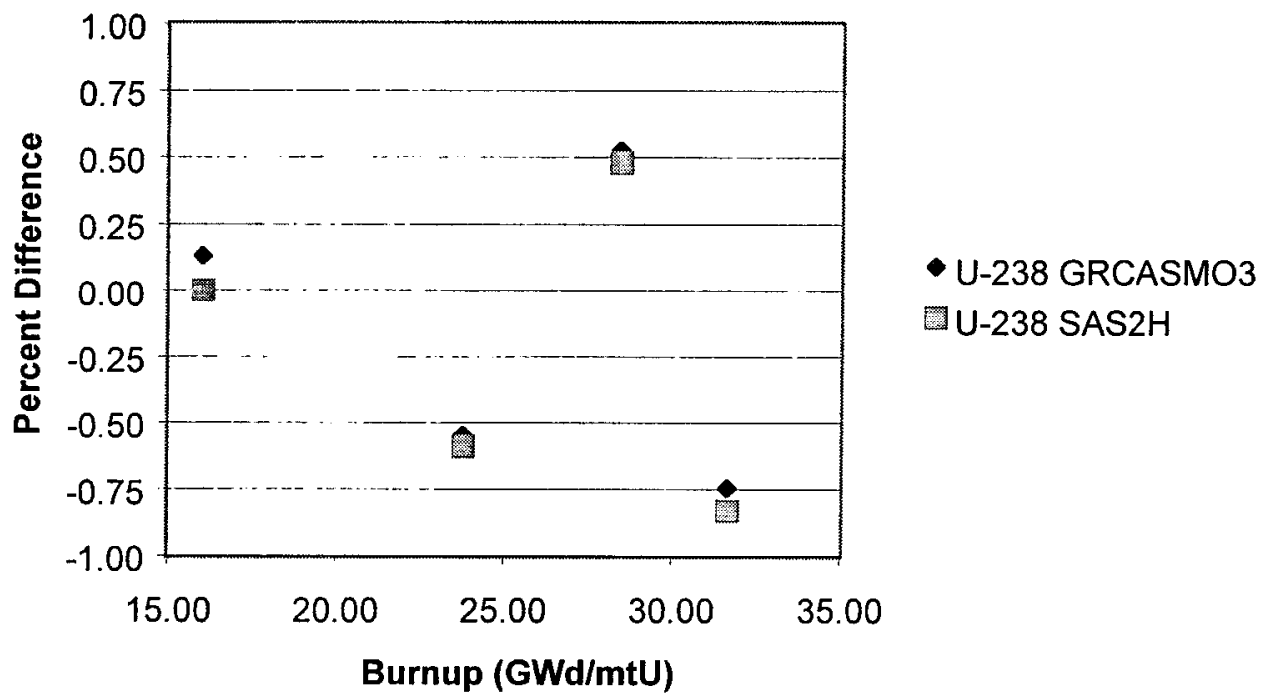

Figure 3-5. H.B. Robinson U-238 Comparison 


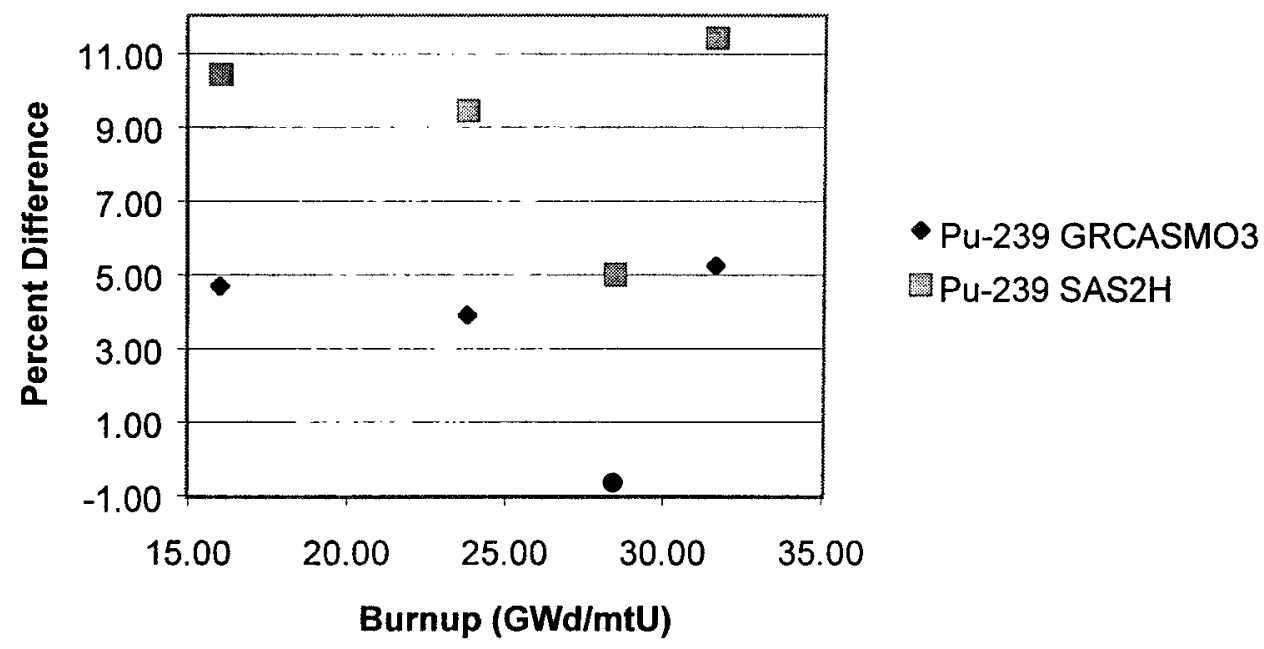

Figure 3-6. H.B. Robinson Pu-239 Comparison

\subsubsection{Obrigheim}

Tables 3-14 through 3-19 contain the results from the RCAs, the SAS2H calculations, and the GRCASMO3 calculations. The results are presented in both density and percent difference between the calculations (SAS2H and GRCASMO3) and the measured (RCA). Figures 3-7 and 3-8 are plots of the top contributors to reactivity - U235 and Pu239 - for all six samples from the Obrigheim plant.

Table 3-14. Obrigheim PWR TA 168 (Batch 86, Burnup $=28.40 \mathrm{GWd} / \mathrm{mtU}$ )

\begin{tabular}{|c|c|c|c|c|c|}
\hline Isotopes & Measured & SAS2H & GRCASMO3 & $\begin{array}{c}\text { GRCASMO3 } \% \\
\text { Difference }\end{array}$ & $\begin{array}{c}\text { SAS2H \% } \\
\text { Difference }\end{array}$ \\
\hline $\mathrm{U}-235$ & $9.68 \mathrm{E}+03$ & $9.98 \mathrm{E}+03$ & $9.50 \mathrm{E}+03$ & -1.86 & 3.10 \\
\hline $\mathrm{U}-236$ & $3.73 \mathrm{E}+03$ & $3.76 \mathrm{E}+03$ & $3.78 \mathrm{E}+03$ & 1.45 & 0.80 \\
\hline $\mathrm{U}-238$ & $\mathrm{~N} / \mathrm{A}$ & $\mathrm{N} / \mathrm{A}$ & $9.48 \mathrm{E}+05$ & $\mathrm{~N} / \mathrm{A}$ & $\mathrm{N} / \mathrm{A}$ \\
\hline $\mathrm{Np}-237$ & $\mathrm{~N} / \mathrm{A}$ & $\mathrm{N} / \mathrm{A}$ & $3.41 \mathrm{E}+02$ & $\mathrm{~N} / \mathrm{A}$ & $\mathrm{N} / \mathrm{A}$ \\
\hline $\mathrm{Pu}-238$ & $1.05 \mathrm{E}+02$ & $1.08 \mathrm{E}+02$ & $1.25 \mathrm{E}+02$ & 18.64 & 2.47 \\
\hline $\mathrm{Pu}-239$ & $5.01 \mathrm{E}+03$ & $4.21 \mathrm{E}+03$ & $4.92 \mathrm{E}+03$ & -1.85 & -16.02 \\
\hline $\mathrm{Pu}-240$ & $2.02 \mathrm{E}+03$ & $2.17 \mathrm{E}+03$ & $1.97 \mathrm{E}+03$ & -2.39 & 7.43 \\
\hline $\mathrm{Pu}-241$ & $1.10 \mathrm{E}+03$ & $1.10 \mathrm{E}+03$ & $1.02 \mathrm{E}+03$ & -7.82 & -0.27 \\
\hline $\mathrm{Pu}-242$ & $4.07 \mathrm{E}+02$ & $4.24 \mathrm{E}+02$ & $3.10 \mathrm{E}+02$ & -23.84 & 4.18 \\
\hline
\end{tabular}

Table 3-15. Obrigheim PWR TA 170 (Batch 94, Burnup $=25.93 \mathrm{GWd} / \mathrm{mtU}$ )

\begin{tabular}{|c|c|c|c|c|c|}
\hline Isotopes & Measured & SAS2H & GRCASMO3 & $\begin{array}{c}\text { GRCASMO3 } \% \\
\text { Difference }\end{array}$ & $\begin{array}{c}\text { SAS2H \% } \\
\text { Difference }\end{array}$ \\
\hline $\mathrm{U}-235$ & $1.10 \mathrm{E}+04$ & $1.11 \mathrm{E}+04$ & $1.07 \mathrm{E}+04$ & -2.30 & 1.37 \\
\hline $\mathrm{U}-236$ & $3.59 \mathrm{E}+03$ & $3.60 \mathrm{E}+03$ & $3.62 \mathrm{E}+03$ & 0.71 & 0.28 \\
\hline $\mathrm{U}-238$ & $\mathrm{~N} / \mathrm{A}$ & $\mathrm{N} / \mathrm{A}$ & $9.50 \mathrm{E}+05$ & $\mathrm{~N} / \mathrm{A}$ & $\mathrm{N} / \mathrm{A}$ \\
\hline $\mathrm{Np}-237$ & $\mathrm{~N} / \mathrm{A}$ & $\mathrm{N} / \mathrm{A}$ & $3.02 \mathrm{E}+02$ & $\mathrm{~N} / \mathrm{A}$ & $\mathrm{N} / \mathrm{A}$ \\
\hline $\mathrm{Pu}-238$ & $8.01 \mathrm{E}+01$ & $8.72 \mathrm{E}+01$ & $9.84 \mathrm{E}+01$ & 22.87 & 8.86 \\
\hline $\mathrm{Pu}-239$ & $4.81 \mathrm{E}+03$ & $4.17 \mathrm{E}+03$ & $4.85 \mathrm{E}+03$ & 0.90 & -13.22 \\
\hline $\mathrm{Pu}-240$ & $1.80 \mathrm{E}+03$ & $1.99 \mathrm{E}+03$ & $1.81 \mathrm{E}+03$ & 0.47 & 10.56 \\
\hline $\mathrm{Pu}-241$ & $9.78 \mathrm{E}+02$ & $1.01 \mathrm{E}+03$ & $9.19 \mathrm{E}+02$ & -6.01 & 3.27 \\
\hline $\mathrm{Pu}-242$ & $3.12 \mathrm{E}+02$ & $3.46 \mathrm{E}+02$ & $2.47 \mathrm{E}+02$ & -20.71 & 10.90 \\
\hline
\end{tabular}


Table 3-16. Obrigheim PWR TA 171 (Batch 89, Burnup = $29.04 \mathrm{GWd} / \mathrm{mtU}$ )

\begin{tabular}{|c|c|c|c|c|c|}
\hline Isotopes & Measured & SAS2H & GRCASMO3 & $\begin{array}{c}\text { GRCASMO3 \% } \\
\text { Difference }\end{array}$ & $\begin{array}{c}\text { SAS2H \% } \\
\text { Difference }\end{array}$ \\
\hline $\mathrm{U}-235$ & $9.58 \mathrm{E}+03$ & $9.70 \mathrm{E}+03$ & $9.20 \mathrm{E}+03$ & -3.96 & 1.25 \\
\hline $\mathrm{U}-236$ & $3.75 \mathrm{E}+03$ & $3.80 \mathrm{E}+03$ & $3.82 \mathrm{E}+03$ & 1.99 & 1.33 \\
\hline $\mathrm{U}-238$ & $\mathrm{~N} / \mathrm{A}$ & $\mathrm{N} / \mathrm{A}$ & $9.48 \mathrm{E}+05$ & $\mathrm{~N} / \mathrm{A}$ & $\mathrm{N} / \mathrm{A}$ \\
\hline $\mathrm{Np}-237$ & $\mathrm{~N} / \mathrm{A}$ & $\mathrm{N} / \mathrm{A}$ & $3.50 \mathrm{E}+02$ & $\mathrm{~N} / \mathrm{A}$ & $\mathrm{N} / \mathrm{A}$ \\
\hline $\mathrm{Pu}-238$ & $1.01 \mathrm{E}+02$ & $1.14 \mathrm{E}+02$ & $1.31 \mathrm{E}+02$ & 29.69 & 12.54 \\
\hline $\mathrm{Pu}-239$ & $4.96 \mathrm{E}+03$ & $4.21 \mathrm{E}+03$ & $4.93 \mathrm{E}+03$ & -0.62 & -15.07 \\
\hline $\mathrm{Pu}-240$ & $2.00 \mathrm{E}+03$ & $2.21 \mathrm{E}+03$ & $2.01 \mathrm{E}+03$ & 0.68 & 10.50 \\
\hline $\mathrm{Pu}-241$ & $1.11 \mathrm{E}+03$ & $1.13 \mathrm{E}+03$ & $1.04 \mathrm{E}+03$ & -6.13 & 2.08 \\
\hline $\mathrm{Pu}-242$ & $4.05 \mathrm{E}+02$ & $4.48 \mathrm{E}+02$ & $3.27 \mathrm{E}+02$ & -19.22 & 10.62 \\
\hline
\end{tabular}

Table 3-17. Obrigheim PWR TA 172 (Batch 92, Burnup = $26.54 \mathrm{GWd} / \mathrm{mtU}$ )

\begin{tabular}{|c|c|c|c|c|c|}
\hline Isotopes & Measured & SAS2H & GRCASMO3 & $\begin{array}{c}\text { GRCASMO3 } \% \\
\text { Difference }\end{array}$ & $\begin{array}{c}\text { SAS2H } \% \\
\text { Difference }\end{array}$ \\
\hline $\mathrm{U}-235$ & $1.06 \mathrm{E}+04$ & $1.08 \mathrm{E}+04$ & $1.04 \mathrm{E}+04$ & -1.87 & 2.08 \\
\hline $\mathrm{U}-236$ & $3.62 \mathrm{E}+03$ & $3.64 \mathrm{E}+03$ & $3.66 \mathrm{E}+03$ & 1.15 & 0.55 \\
\hline $\mathrm{U}-238$ & $\mathrm{~N} / \mathrm{A}$ & $\mathrm{N} / \mathrm{A}$ & $9.50 \mathrm{E}+05$ & $\mathrm{~N} / \mathrm{A}$ & $\mathrm{N} / \mathrm{A}$ \\
\hline $\mathrm{Np}-237$ & $\mathrm{~N} / \mathrm{A}$ & $\mathrm{N} / \mathrm{A}$ & $3.11 \mathrm{E}+02$ & $\mathrm{~N} / \mathrm{A}$ & $\mathrm{N} / \mathrm{A}$ \\
\hline $\mathrm{Pu}-238$ & $8.89 \mathrm{E}+01$ & $9.22 \mathrm{E}+01$ & $1.11 \mathrm{E}+02$ & 24.48 & 3.71 \\
\hline $\mathrm{Pu}-239$ & $4.71 \mathrm{E}+03$ & $4.24 \mathrm{E}+03$ & $4.86 \mathrm{E}+03$ & 3.04 & -10.04 \\
\hline $\mathrm{Pu}-240$ & $1.83 \mathrm{E}+03$ & $2.06 \mathrm{E}+03$ & $1.85 \mathrm{E}+03$ & 1.04 & 12.57 \\
\hline $\mathrm{Pu}-241$ & $9.78 \mathrm{E}+02$ & $1.03 \mathrm{E}+03$ & $9.44 \mathrm{E}+02$ & -3.48 & 5.32 \\
\hline $\mathrm{Pu}-242$ & $3.28 \mathrm{E}+02$ & $3.47 \mathrm{E}+02$ & $2.60 \mathrm{E}+02$ & -20.84 & 5.79 \\
\hline
\end{tabular}

Table 3-18. Obrigheim PWR TA 176 (Batch 90, Burnup = $29.52 \mathrm{GWd} / \mathrm{mtU}$ )

\begin{tabular}{|c|c|c|c|c|c|}
\hline Isotopes & Measured & SAS2H & GRCASMO3 & $\begin{array}{c}\text { GRCASMO3 } \% \\
\text { Difference }\end{array}$ & $\begin{array}{c}\text { SAS2H } \% \\
\text { Difference }\end{array}$ \\
\hline$U-235$ & $9.18 \mathrm{E}+03$ & $9.48 \mathrm{E}+03$ & $8.98 \mathrm{E}+03$ & -2.17 & 3.27 \\
\hline $\mathrm{U}-236$ & $3.81 \mathrm{E}+03$ & $3.83 \mathrm{E}+03$ & $3.85 \mathrm{E}+03$ & 1.17 & 0.52 \\
\hline $\mathrm{U}-238$ & $\mathrm{~N} / \mathrm{A}$ & $\mathrm{N} / \mathrm{A}$ & $9.48 \mathrm{E}+05$ & $\mathrm{~N} / \mathrm{A}$ & $\mathrm{N} / \mathrm{A}$ \\
\hline $\mathrm{Np}-237$ & $\mathrm{~N} / \mathrm{A}$ & $\mathrm{N} / \mathrm{A}$ & $3.57 \mathrm{E}+02$ & $\mathrm{~N} / \mathrm{A}$ & $\mathrm{N} / \mathrm{A}$ \\
\hline $\mathrm{Pu}-238$ & $1.07 \mathrm{E}+02$ & $1.19 \mathrm{E}+02$ & $1.38 \mathrm{E}+02$ & 28.67 & 11.11 \\
\hline $\mathrm{Pu}-239$ & $4.94 \mathrm{E}+03$ & $4.21 \mathrm{E}+03$ & $4.94 \mathrm{E}+03$ & -0.16 & -14.83 \\
\hline $\mathrm{Pu}-240$ & $2.04 \mathrm{E}+03$ & $2.25 \mathrm{E}+03$ & $2.04 \mathrm{E}+03$ & 0.09 & 10.29 \\
\hline $\mathrm{Pu}-241$ & $1.13 \mathrm{E}+03$ & $1.15 \mathrm{E}+03$ & $1.06 \mathrm{E}+03$ & -6.10 & 1.95 \\
\hline $\mathrm{Pu}-242$ & $4.38 \mathrm{E}+02$ & $4.61 \mathrm{E}+02$ & $3.40 \mathrm{E}+02$ & -22.39 & 5.25 \\
\hline
\end{tabular}

Table 3-19. Obrigheim PWR TA 176 (Batch 91, Burnup = 27.99 GWd/mtU)

\begin{tabular}{|c|c|c|c|c|c|}
\hline Isotopes & Measured & SAS2H & GRCASMO3 & $\begin{array}{c}\text { GRCASMO3 } \% \\
\text { Difference }\end{array}$ & $\begin{array}{c}\text { SAS2H \% } \\
\text { Difference }\end{array}$ \\
\hline $\mathrm{U}-235$ & $9.85 \mathrm{E}+03$ & $1.01 \mathrm{E}+04$ & $9.69 \mathrm{E}+03$ & -1.66 & 2.54 \\
\hline $\mathrm{U}-236$ & $3.70 \mathrm{E}+03$ & $3.74 \mathrm{E}+03$ & $3.76 \mathrm{E}+03$ & 1.59 & 1.08 \\
\hline $\mathrm{U}-238$ & $\mathrm{~N} / \mathrm{A}$ & $\mathrm{N} / \mathrm{A}$ & $9.49 \mathrm{E}+05$ & $\mathrm{~N} / \mathrm{A}$ & $\mathrm{N} / \mathrm{A}$ \\
\hline $\mathrm{Np}-237$ & $\mathrm{~N} / \mathrm{A}$ & $\mathrm{N} / \mathrm{A}$ & $3.34 \mathrm{E}+02$ & $\mathrm{~N} / \mathrm{A}$ & $\mathrm{N} / \mathrm{A}$ \\
\hline $\mathrm{Pu}-238$ & $9.48 \mathrm{E}+01$ & $1.05 \mathrm{E}+02$ & $1.22 \mathrm{E}+02$ & 29.02 & 10.76 \\
\hline $\mathrm{Pu}-239$ & $4.93 \mathrm{E}+03$ & $4.23 \mathrm{E}+03$ & $4.90 \mathrm{E}+03$ & -0.52 & -14.11 \\
\hline $\mathrm{Pu}-240$ & $1.92 \mathrm{E}+03$ & $2.14 \mathrm{E}+03$ & $1.95 \mathrm{E}+03$ & 1.36 & 11.46 \\
\hline $\mathrm{Pu}-241$ & $1.06 \mathrm{E}+03$ & $1.08 \mathrm{E}+03$ & $9.98 \mathrm{E}+02$ & -5.62 & 2.08 \\
\hline $\mathrm{Pu}-242$ & $3.72 \mathrm{E}+02$ & $4.05 \mathrm{E}+02$ & $2.98 \mathrm{E}+02$ & -19.81 & 8.87 \\
\hline
\end{tabular}




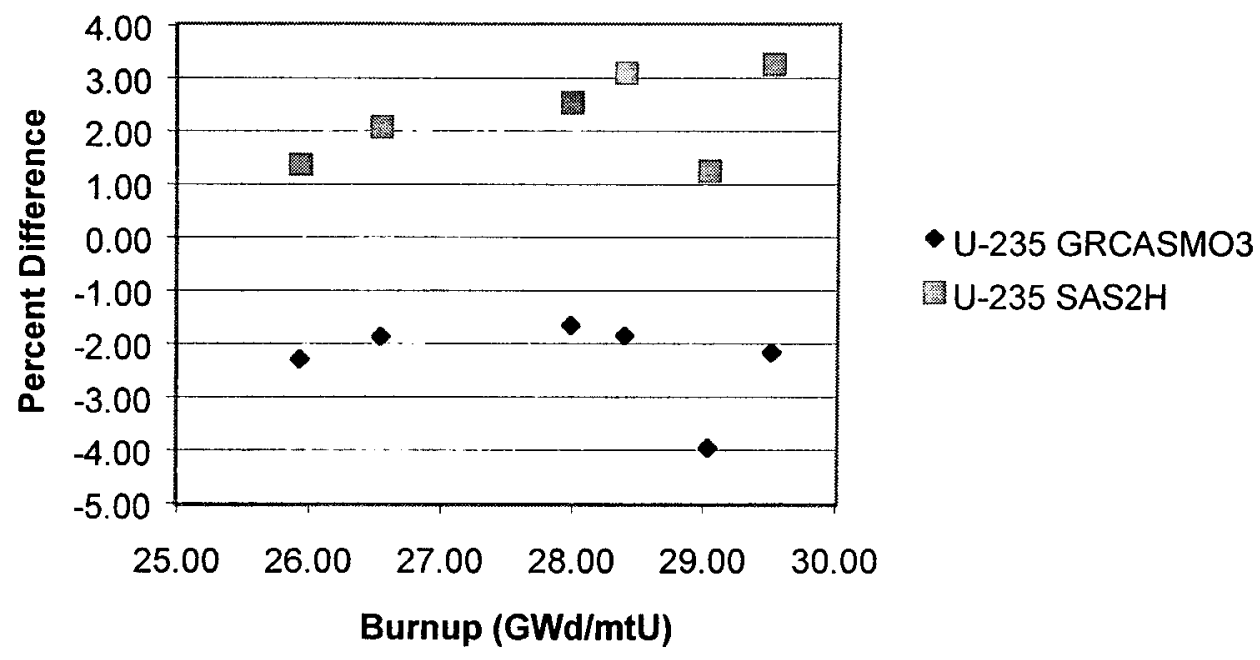

Figure 3-7. Obrigheim U-235 Comparison

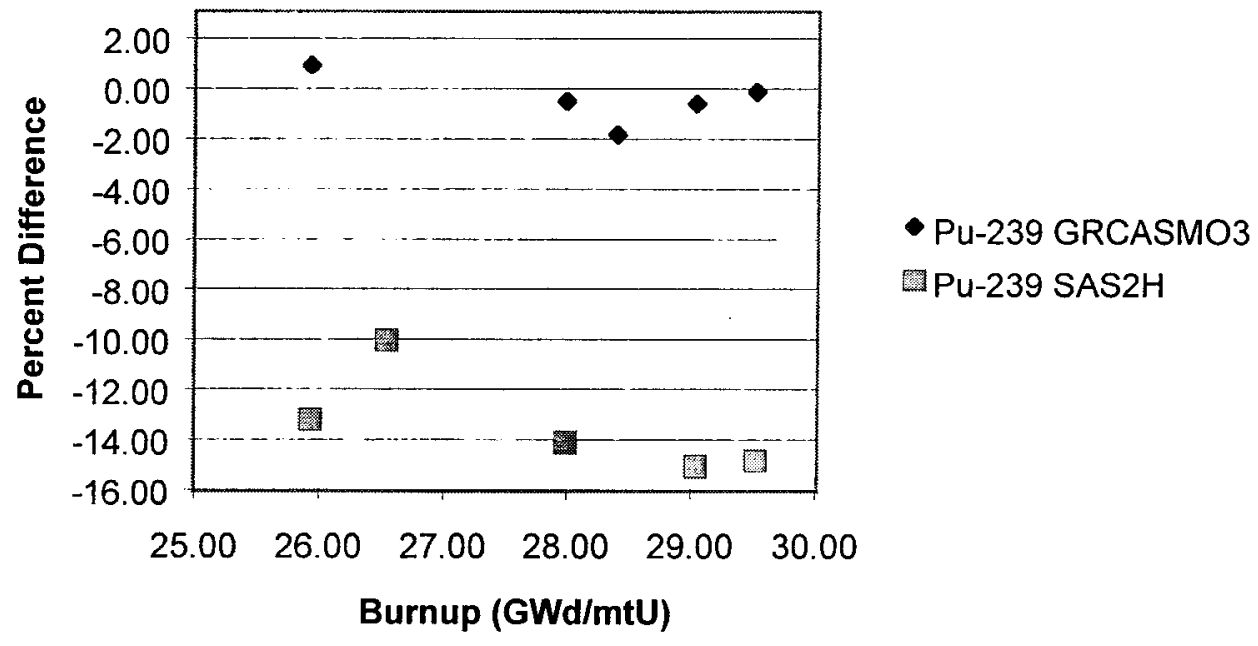

Figure 3-8. Obrigheim Pu-239 Comparison

\subsubsection{Mihama}

Tables 3-20 through 3-28 contain the results from the RCAs, the SAS2H calculations, and the GRCASMO3 calculations. The results are presented in both density and percent difference between the calculations (SAS2H and GRCASMO3) and the measured (RCA). Figures 3-9 through 3-11 are plots of the top three contributors to reactivity, U235, U238, and Pu239 for all nine samples from the Mihama plant. 
Table 3-20. Mihama PWR Sample $86 \mathrm{b02}$ (Burnup $=8.30 \mathrm{GWd} / \mathrm{mtU}$ )

\begin{tabular}{|c|c|c|c|c|c|}
\hline Isotopes & Measured & SAS2H & GRCASMO3 & $\begin{array}{c}\text { GRCASMO3 } \% \\
\text { Difference }\end{array}$ & $\begin{array}{c}\text { SAS2H \% } \\
\text { Difference }\end{array}$ \\
\hline $\mathrm{U}-234$ & $2.67 \mathrm{E}+02$ & $2.53 \mathrm{E}+02$ & $2.54 \mathrm{E}+02$ & -4.79 & -5.24 \\
\hline $\mathrm{U}-235$ & $2.39 \mathrm{E}+04$ & $2.34 \mathrm{E}+04$ & $2.35 \mathrm{E}+04$ & -1.54 & -2.09 \\
\hline $\mathrm{U}-236$ & $1.65 \mathrm{E}+03$ & $1.75 \mathrm{E}+03$ & $1.73 \mathrm{E}+03$ & 4.77 & 6.06 \\
\hline $\mathrm{U}-238$ & $9.62 \mathrm{E}+05$ & $9.62 \mathrm{E}+05$ & $9.62 \mathrm{E}+05$ & 0.03 & 0.00 \\
\hline $\mathrm{Np}-237$ & $\mathrm{~N} / \mathrm{A}$ & $\mathrm{N} / \mathrm{A}$ & $6.43 \mathrm{E}+01$ & $\mathrm{~N} / \mathrm{A}$ & $\mathrm{N} / \mathrm{A}$ \\
\hline $\mathrm{Pu}-238$ & $4.51 \mathrm{E}+00$ & $4.54 \mathrm{E}+00$ & $5.07 \mathrm{E}+00$ & 12.49 & 0.67 \\
\hline $\mathrm{Pu}-239$ & $3.02 \mathrm{E}+03$ & $3.05 \mathrm{E}+03$ & $3.02 \mathrm{E}+03$ & 0.06 & 0.99 \\
\hline $\mathrm{Pu}-240$ & $4.22 \mathrm{E}+02$ & $4.30 \mathrm{E}+02$ & $4.17 \mathrm{E}+02$ & -1.18 & 1.90 \\
\hline $\mathrm{Pu}-241$ & $1.09 \mathrm{E}+02$ & $1.09 \mathrm{E}+02$ & $1.02 \mathrm{E}+02$ & -6.64 & 0.00 \\
\hline $\mathrm{Pu}-242$ & $9.49 \mathrm{E}+00$ & $1.02 \mathrm{E}+01$ & $8.30 \mathrm{E}+00$ & -12.56 & 7.48 \\
\hline
\end{tabular}

Table 3-21. Mihama PWR Sample $86 \mathrm{b03}$ (Burnup $=6.92 \mathrm{GWd} / \mathrm{mtU}$ )

\begin{tabular}{|c|c|c|c|c|c|}
\hline Isotopes & Measured & SAS2H & GRCASMO3 & $\begin{array}{c}\text { GRCASMO3 } \% \\
\text { Difference }\end{array}$ & $\begin{array}{c}\text { SAS2H } \% \\
\text { Difference }\end{array}$ \\
\hline $\mathrm{U}-234$ & $\mathrm{~N} / \mathrm{A}$ & $\mathrm{N} / \mathrm{A}$ & $2.58 \mathrm{E}+02$ & $\mathrm{~N} / \mathrm{A}$ & N/A \\
\hline $\mathrm{U}-235$ & $2.52 \mathrm{E}+04$ & $2.48 \mathrm{E}+04$ & $2.49 \mathrm{E}+04$ & -1.32 & -1.59 \\
\hline $\mathrm{U}-236$ & $1.46 \mathrm{E}+03$ & $1.53 \mathrm{E}+03$ & $1.52 \mathrm{E}+03$ & 3.89 & 4.79 \\
\hline $\mathrm{U}-238$ & $9.62 \mathrm{E}+05$ & $9.63 \mathrm{E}+05$ & $9.63 \mathrm{E}+05$ & 0.10 & 0.10 \\
\hline $\mathrm{Np}-237$ & $\mathrm{~N} / \mathrm{A}$ & $\mathrm{N} / \mathrm{A}$ & $5.35 \mathrm{E}+01$ & $\mathrm{~N} / \mathrm{A}$ & $\mathrm{N} / \mathrm{A}$ \\
\hline $\mathrm{Pu}-238$ & $3.41 \mathrm{E}+00$ & $3.30 \mathrm{E}+00$ & $3.71 \mathrm{E}+00$ & 8.70 & -3.23 \\
\hline $\mathrm{Pu}-239$ & $2.83 \mathrm{E}+03$ & $2.81 \mathrm{E}+03$ & $2.79 \mathrm{E}+03$ & -1.57 & -0.71 \\
\hline $\mathrm{Pu}-240$ & $3.44 \mathrm{E}+02$ & $3.47 \mathrm{E}+02$ & $3.36 \mathrm{E}+02$ & -2.27 & 0.87 \\
\hline $\mathrm{Pu}-241$ & $8.28 \mathrm{E}+01$ & $8.16 \mathrm{E}+01$ & $7.54 \mathrm{E}+01$ & -8.92 & -1.45 \\
\hline $\mathrm{Pu}-242$ & $6.04 \mathrm{E}+00$ & $6.26 \mathrm{E}+00$ & $5.03 \mathrm{E}+00$ & -16.74 & 3.64 \\
\hline
\end{tabular}

Table 3-22. Mihama PWR Sample $86 \mathrm{~g} 03$ (Burnup $=21.29 \mathrm{GWd} / \mathrm{mtU}$ )

\begin{tabular}{|c|c|c|c|c|c|}
\hline Isotopes & Measured & SAS2H & GRCASMO3 & $\begin{array}{c}\text { GRCASMO3 \% } \\
\text { Difference }\end{array}$ & $\begin{array}{c}\text { SAS2H \% } \\
\text { Difference }\end{array}$ \\
\hline$U-234$ & N/A & N/A & $2.07 \mathrm{E}+02$ & N/A & N/A \\
\hline$U-235$ & $1.45 \mathrm{E}+04$ & $1.39 \mathrm{E}+04$ & $1.40 \mathrm{E}+04$ & -3.19 & -4.14 \\
\hline $\mathrm{U}-236$ & $3.27 \mathrm{E}+03$ & $3.25 \mathrm{E}+03$ & $3.24 \mathrm{E}+03$ & -0.98 & -0.61 \\
\hline $\mathrm{U}-238$ & $9.52 \mathrm{E}+05$ & $9.52 \mathrm{E}+05$ & $9.53 \mathrm{E}+05$ & 0.10 & 0.00 \\
\hline $\mathrm{Np}-237$ & $\mathrm{~N} / \mathrm{A}$ & $\mathrm{N} / \mathrm{A}$ & $2.39 \mathrm{E}+02$ & $\mathrm{~N} / \mathrm{A}$ & $\mathrm{N} / \mathrm{A}$ \\
\hline $\mathrm{Pu}-238$ & $5.72 \mathrm{E}+01$ & $5.01 \mathrm{E}+01$ & $7.61 \mathrm{E}+01$ & 33.11 & -12.41 \\
\hline $\mathrm{Pu}-239$ & $5.08 \mathrm{E}+03$ & $4.98 \mathrm{E}+03$ & $4.87 \mathrm{E}+03$ & -4.14 & -1.97 \\
\hline $\mathrm{Pu}-240$ & $1.49 \mathrm{E}+03$ & $1.51 \mathrm{E}+03$ & $1.48 \mathrm{E}+03$ & -0.47 & 1.34 \\
\hline $\mathrm{Pu}-241$ & $6.51 \mathrm{E}+02$ & $6.14 \mathrm{E}+02$ & $5.88 \mathrm{E}+02$ & -9.72 & -5.68 \\
\hline $\mathrm{Pu}-242$ & $1.76 \mathrm{E}+02$ & $1.76 \mathrm{E}+02$ & $1.47 \mathrm{E}+02$ & -16.25 & 0.00 \\
\hline
\end{tabular}

Table 3-23. Mihama PWR Sample 86g05 (Burnup $=15.36 \mathrm{GWd} / \mathrm{mtU}$ )

\begin{tabular}{|c|c|c|c|c|c|}
\hline Isotopes & Measured & SAS2H & GRCASMO3 & $\begin{array}{c}\text { GRCASMO3 } \% \\
\text { Difference }\end{array}$ & $\begin{array}{c}\text { SAS2H \% } \\
\text { Difference }\end{array}$ \\
\hline $\mathrm{U}-234$ & $\mathrm{~N} / \mathrm{A}$ & $\mathrm{N} / \mathrm{A}$ & $2.28 \mathrm{E}+02$ & N/A & N/A \\
\hline $\mathrm{U}-235$ & $1.85 \mathrm{E}+04$ & $1.77 \mathrm{E}+04$ & $1.78 \mathrm{E}+04$ & -3.57 & -4.32 \\
\hline $\mathrm{U}-236$ & $2.65 \mathrm{E}+03$ & $2.63 \mathrm{E}+03$ & $2.60 \mathrm{E}+03$ & -1.72 & -0.75 \\
\hline $\mathrm{U}-238$ & $9.56 \mathrm{E}+05$ & $9.57 \mathrm{E}+05$ & $9.58 \mathrm{E}+05$ & 0.16 & 0.10 \\
\hline $\mathrm{Np}-237$ & $\mathrm{~N} / \mathrm{A}$ & $\mathrm{N} / \mathrm{A}$ & $1.48 \mathrm{E}+02$ & $\mathrm{~N} / \mathrm{A}$ & $\mathrm{N} / \mathrm{A}$ \\
\hline $\mathrm{Pu}-238$ & $2.59 \mathrm{E}+01$ & $2.18 \mathrm{E}+01$ & $3.20 \mathrm{E}+01$ & 23.49 & -15.83 \\
\hline $\mathrm{Pu}-239$ & $4.65 \mathrm{E}+03$ & $4.30 \mathrm{E}+03$ & $4.23 \mathrm{E}+03$ & -8.94 & -7.53 \\
\hline $\mathrm{Pu}-240$ & $1.03 \mathrm{E}+03$ & $1.01 \mathrm{E}+03$ & $9.95 \mathrm{E}+02$ & -3.40 & -1.94 \\
\hline $\mathrm{Pu}-241$ & $4.08 \mathrm{E}+02$ & $3.62 \mathrm{E}+02$ & $3.41 \mathrm{E}+02$ & -16.32 & -11.27 \\
\hline
\end{tabular}


Table 3-23. Mihama PWR Sample 86g05 (Burnup = $15.36 \mathrm{GWd} / \mathrm{mtU}$ )

\begin{tabular}{|c|c|c|c|c|c|}
\hline Isotopes & Measured & SAS2H & GRCASMO3 & $\begin{array}{c}\text { GRCASMO3 } \% \\
\text { Difference }\end{array}$ & $\begin{array}{c}\text { SAS2H } \% \\
\text { Difference }\end{array}$ \\
\hline Pu-242 & $7.39 \mathrm{E}+01$ & $7.04 \mathrm{E}+01$ & $5.72 \mathrm{E}+01$ & -22.63 & -4.74 \\
\hline
\end{tabular}

Table 3-24. Mihama PWR Sample $86 \mathrm{~g} 07$ (Burnup $=14.66 \mathrm{GWd} / \mathrm{mtU}$ )

\begin{tabular}{|c|c|c|c|c|c|}
\hline Isotopes & Measured & SAS2H & GRCASMO3 & $\begin{array}{c}\text { GRCASMO3 \% } \\
\text { Difference }\end{array}$ & $\begin{array}{c}\text { SAS2H \% } \\
\text { Difference }\end{array}$ \\
\hline$U-234$ & $\mathrm{~N} / \mathrm{A}$ & $\mathrm{N} / \mathrm{A}$ & $2.30 \mathrm{E}+02$ & N/A & N/A \\
\hline $\mathrm{U}-235$ & $1.84 \mathrm{E}+04$ & $1.83 \mathrm{E}+04$ & $1.84 \mathrm{E}+04$ & 0.19 & -0.54 \\
\hline $\mathrm{U}-236$ & $2.66 \mathrm{E}+03$ & $2.54 \mathrm{E}+03$ & $2.52 \mathrm{E}+03$ & -5.22 & -4.51 \\
\hline $\mathrm{U}-238$ & $9.57 \mathrm{E}+05$ & $9.57 \mathrm{E}+05$ & $9.58 \mathrm{E}+05$ & 0.09 & 0.00 \\
\hline $\mathrm{Np}-237$ & $\mathrm{~N} / \mathrm{A}$ & $\mathrm{N} / \mathrm{A}$ & $1.42 \mathrm{E}+02$ & $\mathrm{~N} / \mathrm{A}$ & $\mathrm{N} / \mathrm{A}$ \\
\hline $\mathrm{Pu}-238$ & $2.68 \mathrm{E}+01$ & $2.03 \mathrm{E}+01$ & $2.96 \mathrm{E}+01$ & 10.63 & -24.25 \\
\hline $\mathrm{Pu}-239$ & $4.74 \mathrm{E}+03$ & $4.29 \mathrm{E}+03$ & $4.22 \mathrm{E}+03$ & -10.88 & -9.49 \\
\hline $\mathrm{Pu}-240$ & $1.06 \mathrm{E}+03$ & $9.69 \mathrm{E}+02$ & $9.54 \mathrm{E}+02$ & -9.97 & -8.58 \\
\hline $\mathrm{Pu}-241$ & $4.25 \mathrm{E}+02$ & $3.47 \mathrm{E}+02$ & $3.26 \mathrm{E}+02$ & -23.38 & -18.35 \\
\hline $\mathrm{Pu}-242$ & $7.51 \mathrm{E}+01$ & $6.33 \mathrm{E}+01$ & $5.13 \mathrm{E}+01$ & -31.75 & -15.71 \\
\hline
\end{tabular}

Table 3-25. Mihama PWR Sample $87 \mathrm{c03}$ (Burnup $=29.50 \mathrm{GWd} / \mathrm{mtU}$ )

\begin{tabular}{|c|c|c|c|c|c|}
\hline Isotopes & Measured & SAS2H & GRCASMO3 & $\begin{array}{c}\text { GRCASMO3 \% } \\
\text { Difference }\end{array}$ & $\begin{array}{c}\text { SAS2H \% } \\
\text { Difference }\end{array}$ \\
\hline$U-234$ & N/A & N/A & $1.87 \mathrm{E}+02$ & N/A & N/A \\
\hline$U-235$ & $9.79 \mathrm{E}+03$ & $9.40 \mathrm{E}+03$ & $9.45 \mathrm{E}+03$ & -3.45 & -3.98 \\
\hline $\mathrm{U}-236$ & $3.83 \mathrm{E}+03$ & $4.08 \mathrm{E}+03$ & $4.08 \mathrm{E}+03$ & 6.45 & 6.53 \\
\hline $\mathrm{U}-238$ & $9.47 \mathrm{E}+05$ & $9.46 \mathrm{E}+05$ & $9.47 \mathrm{E}+05$ & -0.01 & -0.11 \\
\hline $\mathrm{Np}-237$ & $\mathrm{~N} / \mathrm{A}$ & $\mathrm{N} / \mathrm{A}$ & $3.73 \mathrm{E}+02$ & $\mathrm{~N} / \mathrm{A}$ & $\mathrm{N} / \mathrm{A}$ \\
\hline $\mathrm{Pu}-238$ & $1.31 \mathrm{E}+02$ & $1.15 \mathrm{E}+02$ & $1.66 \mathrm{E}+02$ & 27.07 & -12.21 \\
\hline $\mathrm{Pu}-239$ & $5.30 \mathrm{E}+03$ & $5.11 \mathrm{E}+03$ & $4.97 \mathrm{E}+03$ & -6.20 & -3.58 \\
\hline $\mathrm{Pu}-240$ & $2.10 \mathrm{E}+03$ & $2.05 \mathrm{E}+03$ & $2.01 \mathrm{E}+03$ & -4.49 & -2.38 \\
\hline $\mathrm{Pu}-241$ & $9.55 \mathrm{E}+02$ & $8.43 \mathrm{E}+02$ & $8.32 \mathrm{E}+02$ & -12.85 & -11.73 \\
\hline $\mathrm{Pu}-242$ & $4.08 \mathrm{E}+02$ & $3.81 \mathrm{E}+02$ & $3.29 \mathrm{E}+02$ & -19.44 & -6.62 \\
\hline
\end{tabular}

Table 3-26. Mihama PWR Sample 87c04 (Burnup $=32.20 \mathrm{GWd} / \mathrm{mtU}$ )

\begin{tabular}{|c|c|c|c|c|c|}
\hline Isotopes & Measured & SAS2H & GRCASMO3 & $\begin{array}{c}\text { GRCASMO3 } \% \\
\text { Difference }\end{array}$ & $\begin{array}{c}\text { SAS2H \% } \\
\text { Difference }\end{array}$ \\
\hline $\mathrm{U}-234$ & $1.74 \mathrm{E}+02$ & $1.82 \mathrm{E}+02$ & $1.78 \mathrm{E}+02$ & 2.22 & 4.60 \\
\hline $\mathrm{U}-235$ & $9.07 \mathrm{E}+03$ & $8.31 \mathrm{E}+03$ & $8.33 \mathrm{E}+03$ & -8.11 & -8.38 \\
\hline $\mathrm{U}-236$ & $4.00 \mathrm{E}+03$ & $4.23 \mathrm{E}+03$ & $4.23 \mathrm{E}+03$ & 5.71 & 5.75 \\
\hline $\mathrm{U}-238$ & $9.44 \mathrm{E}+05$ & $9.44 \mathrm{E}+05$ & $9.45 \mathrm{E}+05$ & 0.06 & 0.00 \\
\hline $\mathrm{Np}-237$ & $\mathrm{~N} / \mathrm{A}$ & $\mathrm{N} / \mathrm{A}$ & $4.20 \mathrm{E}+02$ & $\mathrm{~N} / \mathrm{A}$ & $\mathrm{N} / \mathrm{A}$ \\
\hline $\mathrm{Pu}-238$ & $1.59 \mathrm{E}+02$ & $1.41 \mathrm{E}+02$ & $2.04 \mathrm{E}+02$ & 28.44 & -11.32 \\
\hline $\mathrm{Pu}-239$ & $5.47 \mathrm{E}+03$ & $5.21 \mathrm{E}+03$ & $5.05 \mathrm{E}+03$ & -7.60 & -4.75 \\
\hline $\mathrm{Pu}-240$ & $2.27 \mathrm{E}+03$ & $2.23 \mathrm{E}+03$ & $2.18 \mathrm{E}+03$ & -4.14 & -1.76 \\
\hline $\mathrm{Pu}-241$ & $1.06 \mathrm{E}+03$ & $9.31 \mathrm{E}+02$ & $9.20 \mathrm{E}+02$ & -13.24 & -12.17 \\
\hline $\mathrm{Pu}-242$ & $4.90 \mathrm{E}+02$ & $4.92 \mathrm{E}+02$ & $4.08 \mathrm{E}+02$ & -16.71 & 0.41 \\
\hline
\end{tabular}


Table 3-27. Mihama PWR Sample 87c07 (Burnup $=33.71 \mathrm{GWd} / \mathrm{mtU}$ )

\begin{tabular}{|c|c|c|c|c|c|}
\hline Isotopes & Measured & SAS2H & GRCASMO3 & $\begin{array}{c}\text { GRCASMO3 \% } \\
\text { Difference }\end{array}$ & $\begin{array}{c}\text { SAS2H \% } \\
\text { Difference }\end{array}$ \\
\hline $\mathrm{U}-234$ & $1.74 \mathrm{E}+02$ & $1.78 \mathrm{E}+02$ & $1.73 \mathrm{E}+02$ & -0.43 & 2.30 \\
\hline $\mathrm{U}-235$ & $7.89 \mathrm{E}+03$ & $7.63 \mathrm{E}+03$ & $7.64 \mathrm{E}+03$ & -3.15 & -3.30 \\
\hline $\mathrm{U}-236$ & $4.18 \mathrm{E}+03$ & $4.31 \mathrm{E}+03$ & $4.31 \mathrm{E}+03$ & 3.02 & 3.11 \\
\hline $\mathrm{U}-238$ & $9.44 \mathrm{E}+05$ & $9.43 \mathrm{E}+05$ & $9.43 \mathrm{E}+05$ & -0.06 & -0.11 \\
\hline $\mathrm{Np}-237$ & $\mathrm{~N} / \mathrm{A}$ & $\mathrm{N} / \mathrm{A}$ & $4.40 \mathrm{E}+02$ & $\mathrm{~N} / \mathrm{A}$ & $\mathrm{N} / \mathrm{A}$ \\
\hline $\mathrm{Pu}-238$ & $1.68 \mathrm{E}+02$ & $1.54 \mathrm{E}+02$ & $2.22 \mathrm{E}+02$ & 31.89 & -8.33 \\
\hline $\mathrm{Pu}-239$ & $4.97 \mathrm{E}+03$ & $5.19 \mathrm{E}+03$ & $5.03 \mathrm{E}+03$ & 1.14 & 4.43 \\
\hline $\mathrm{Pu}-240$ & $2.32 \mathrm{E}+03$ & $2.30 \mathrm{E}+03$ & $2.25 \mathrm{E}+03$ & -3.09 & -0.86 \\
\hline $\mathrm{Pu}-241$ & $9.83 \mathrm{E}+02$ & $9.58 \mathrm{E}+02$ & $9.47 \mathrm{E}+02$ & -3.64 & -2.54 \\
\hline $\mathrm{Pu}-242$ & $5.34 \mathrm{E}+02$ & $5.19 \mathrm{E}+02$ & $4.53 \mathrm{E}+02$ & -15.17 & -2.81 \\
\hline
\end{tabular}

Table 3-28. Mihama PWR Sample 87c08 (Burnup $=34.32 \mathrm{GWd} / \mathrm{mtU}$ )

\begin{tabular}{|c|c|c|c|c|c|}
\hline Isotopes & Measured & SAS2H & GRCASMO3 & $\begin{array}{c}\text { GRCASMO3 \% } \\
\text { Difference }\end{array}$ & $\begin{array}{c}\text { SAS2H \% } \\
\text { Difference }\end{array}$ \\
\hline $\mathrm{U}-234$ & N/A & N/A & $1.70 \mathrm{E}+02$ & N/A & N/A \\
\hline$U-235$ & $8.04 \mathrm{E}+03$ & $7.77 \mathrm{E}+03$ & $7.75 \mathrm{E}+03$ & -3.62 & -3.36 \\
\hline $\mathrm{U}-236$ & $4.20 \mathrm{E}+03$ & $4.32 \mathrm{E}+03$ & $4.32 \mathrm{E}+03$ & 2.88 & 2.86 \\
\hline $\mathrm{U}-238$ & $9.42 \mathrm{E}+05$ & $9.42 \mathrm{E}+05$ & $9.42 \mathrm{E}+05$ & 0.02 & 0.00 \\
\hline $\mathrm{Np}-237$ & $\mathrm{~N} / \mathrm{A}$ & $\mathrm{N} / \mathrm{A}$ & $4.66 \mathrm{E}+02$ & $\mathrm{~N} / \mathrm{A}$ & $\mathrm{N} / \mathrm{A}$ \\
\hline $\mathrm{Pu}-238$ & $1.86 \mathrm{E}+02$ & $1.69 \mathrm{E}+02$ & $2.45 \mathrm{E}+02$ & 31.55 & -9.14 \\
\hline $\mathrm{Pu}-239$ & $5.32 \mathrm{E}+03$ & $5.45 \mathrm{E}+03$ & $5.25 \mathrm{E}+03$ & -1.27 & 2.44 \\
\hline $\mathrm{Pu}-240$ & $2.43 \mathrm{E}+03$ & $2.39 \mathrm{E}+03$ & $2.33 \mathrm{E}+03$ & -4.09 & -1.65 \\
\hline $\mathrm{Pu}-241$ & $1.08 \mathrm{E}+03$ & $1.03 \mathrm{E}+03$ & $1.02 \mathrm{E}+03$ & -6.00 & -4.63 \\
\hline $\mathrm{Pu}-242$ & $5.70 \mathrm{E}+02$ & $5.45 \mathrm{E}+02$ & $4.77 \mathrm{E}+02$ & -16.32 & -4.39 \\
\hline
\end{tabular}

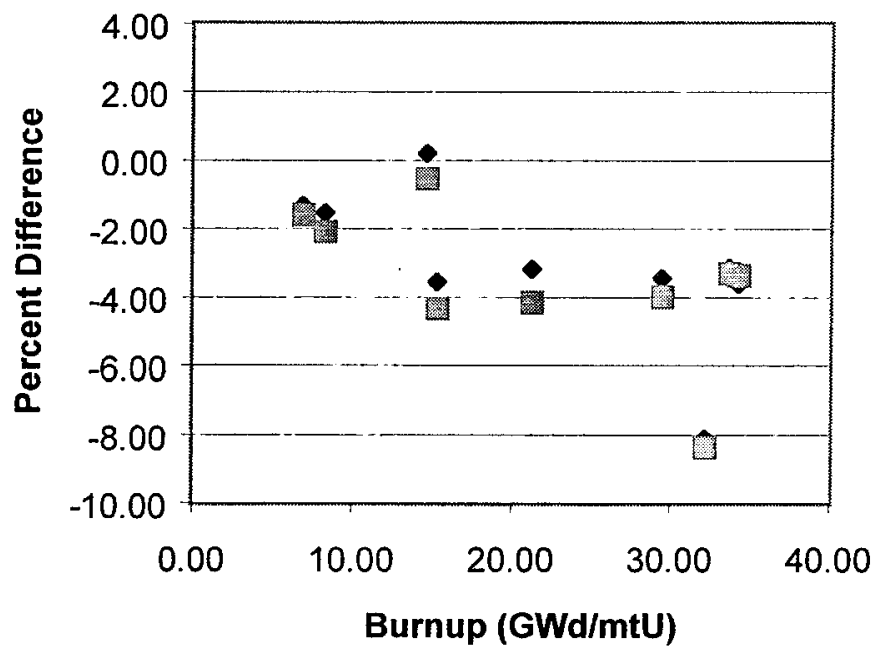

U-235 GRCASMO3

DU-235 SAS2H

Figure 3-9. MihamaU-235 Comparison 


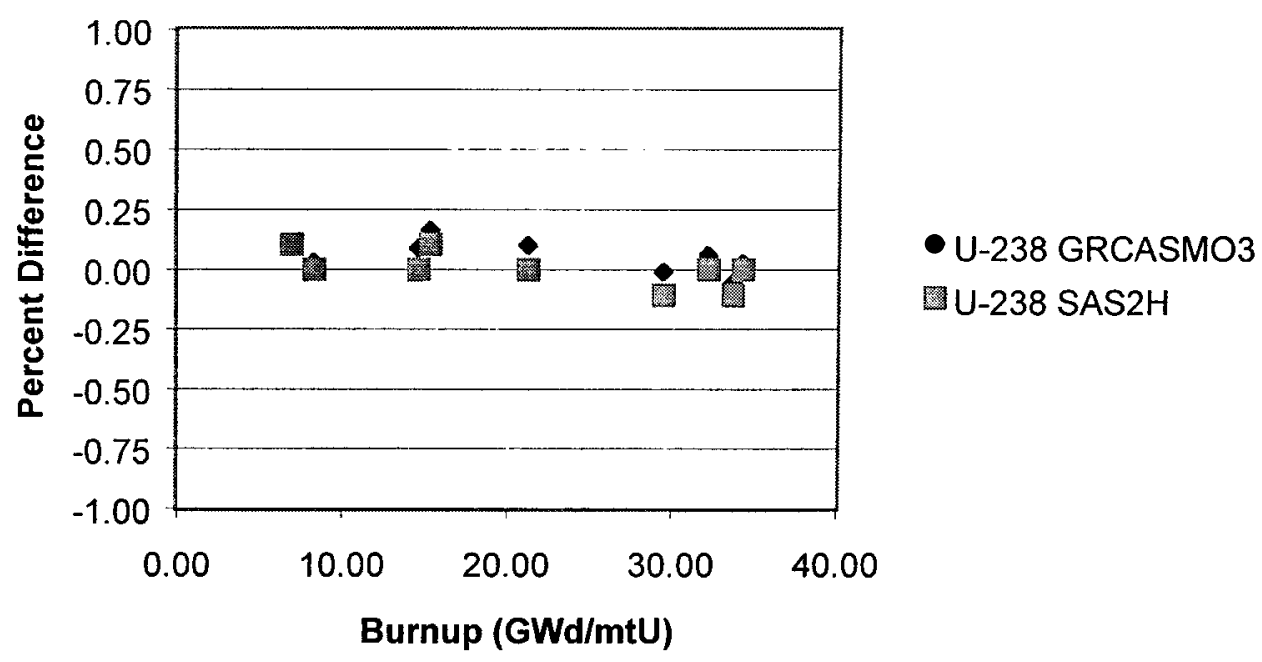

Figure 3-10. Mihama U-238 Comparison

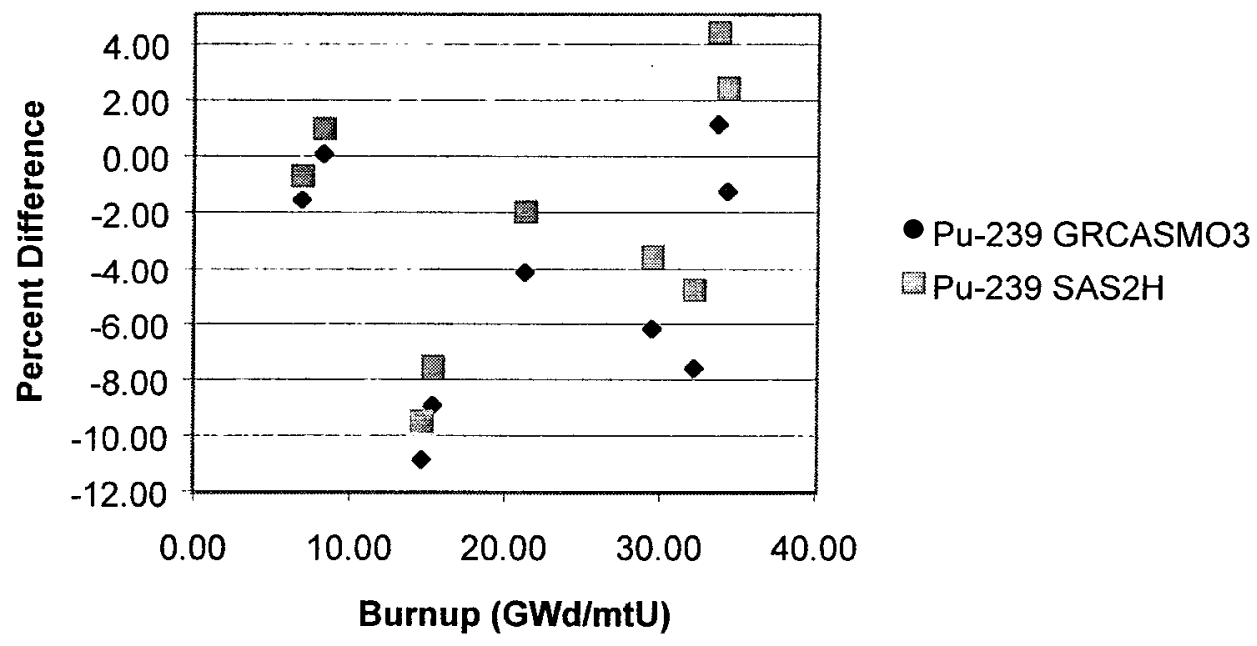

Figure 3-11. Mihama Pu-239 Comparison

\subsubsection{Trino Vercelles}

Tables 3-29 through 3-42 contain the results from the RCAs, the SAS2H calculations, and the GRCASMO3 calculations. The results are presented in both density and percent difference between the calculations (SAS2H and GRCASMO3) and the measured (RCA). Figures 3-12 through 3-14 are plots of the top three contributors to reactivity, U235, U238, and Pu239 for all 14 samples from the Trino Vercelles plant. 
Table 3-29. Trino Vercelles FA 509-104 (Rod M11, AL $=79.2 \mathrm{~cm}$, Burnup $=12.04 \mathrm{GWd} / \mathrm{mtU})$

\begin{tabular}{|c|c|c|c|c|c|}
\hline Isotopes & Measured & SAS2H & GRCASMO3 & $\begin{array}{c}\text { GRCASMO3 } \% \\
\text { Difference }\end{array}$ & $\begin{array}{c}\text { SAS2H \% } \\
\text { Difference }\end{array}$ \\
\hline$U-234$ & & & $2.95 \mathrm{E}+02$ & & \\
\hline$U-235$ & $2.66 \mathrm{E}+04$ & $2.69 \mathrm{E}+04$ & $2.70 \mathrm{E}+04$ & 1.53 & 1.05 \\
\hline$U-236$ & $2.74 \mathrm{E}+03$ & $2.46 \mathrm{E}+03$ & $2.43 \mathrm{E}+03$ & -11.13 & -10.09 \\
\hline $\mathrm{U}-238$ & $9.51 \mathrm{E}+05$ & $9.52 \mathrm{E}+05$ & $9.52 \mathrm{E}+05$ & 0.11 & 0.07 \\
\hline $\mathrm{Np}-237$ & $\mathrm{~N} / \mathrm{A}$ & $\mathrm{N} / \mathrm{A}$ & $1.25 \mathrm{E}+02$ & $\mathrm{~N} / \mathrm{A}$ & $\mathrm{N} / \mathrm{A}$ \\
\hline $\mathrm{Pu}-238$ & $\mathrm{~N} / \mathrm{A}$ & $\mathrm{N} / \mathrm{A}$ & $1.73 \mathrm{E}+01$ & $\mathrm{~N} / \mathrm{A}$ & $\mathrm{N} / \mathrm{A}$ \\
\hline $\mathrm{Pu}-239$ & $4.59 \mathrm{E}+03$ & $4.45 \mathrm{E}+03$ & $4.36 \mathrm{E}+03$ & -4.93 & -2.97 \\
\hline $\mathrm{Pu}-240$ & $7.17 \mathrm{E}+02$ & $6.77 \mathrm{E}+02$ & $6.63 \mathrm{E}+02$ & -7.42 & -5.51 \\
\hline $\mathrm{Pu}-241$ & $3.48 \mathrm{E}+02$ & $3.06 \mathrm{E}+02$ & $2.46 \mathrm{E}+02$ & -29.22 & -11.94 \\
\hline $\mathrm{Pu}-242$ & $3.14 \mathrm{E}+01$ & $2.72 \mathrm{E}+01$ & $2.15 \mathrm{E}+01$ & -31.32 & -13.24 \\
\hline $\mathrm{Am}-241$ & $\mathrm{~N} / \mathrm{A}$ & $\mathrm{N} / \mathrm{A}$ & $4.81 \mathrm{E}+01$ & $\mathrm{~N} / \mathrm{A}$ & $\mathrm{N} / \mathrm{A}$ \\
\hline $\mathrm{Am}-242$ & $\mathrm{~N} / \mathrm{A}$ & $\mathrm{N} / \mathrm{A}$ & $1.85 \mathrm{E}-01$ & $\mathrm{~N} / \mathrm{A}$ & $\mathrm{N} / \mathrm{A}$ \\
\hline $\mathrm{Am}-243$ & $\mathrm{~N} / \mathrm{A}$ & $\mathrm{N} / \mathrm{A}$ & $1.34 \mathrm{E}+00$ & $\mathrm{~N} / \mathrm{A}$ & $\mathrm{N} / \mathrm{A}$ \\
\hline
\end{tabular}

Table 3-30. Trino Vercelles FA 509-032 (Rod E11, AL $=158.5 \mathrm{~cm}$, Burnup $=15.38 \mathrm{GWd} / \mathrm{mtU})$

\begin{tabular}{|c|c|c|c|c|c|}
\hline Isotopes & Measured & SAS2H & GRCASMO3 & $\begin{array}{c}\text { GRCASMO3 } \% \\
\text { Difference }\end{array}$ & $\begin{array}{c}\text { SAS2H } \% \\
\text { Difference }\end{array}$ \\
\hline$U-234$ & N/A & N/A & $2.18 E+02$ & N/A & N/A \\
\hline$U-235$ & $1.73 \mathrm{E}+04$ & $1.77 \mathrm{E}+04$ & $1.78 \mathrm{E}+04$ & 3.11 & 2.43 \\
\hline$U-236$ & $2.83 \mathrm{E}+03$ & $2.62 \mathrm{E}+03$ & $2.61 \mathrm{E}+03$ & -7.99 & -7.55 \\
\hline $\mathrm{U}-238$ & $9.56 \mathrm{E}+05$ & $9.56 \mathrm{E}+05$ & $9.56 \mathrm{E}+05$ & 0.06 & 0.02 \\
\hline $\mathrm{Np}-237$ & $\mathrm{~N} / \mathrm{A}$ & $\mathrm{N} / \mathrm{A}$ & $1.80 \mathrm{E}+02$ & $\mathrm{~N} / \mathrm{A}$ & $\mathrm{N} / \mathrm{A}$ \\
\hline $\mathrm{Pu}-238$ & $\mathrm{~N} / \mathrm{A}$ & $\mathrm{N} / \mathrm{A}$ & $3.98 \mathrm{E}+01$ & $\mathrm{~N} / \mathrm{A}$ & $\mathrm{N} / \mathrm{A}$ \\
\hline $\mathrm{Pu}-239$ & $5.27 \mathrm{E}+03$ & $5.25 \mathrm{E}+03$ & $5.12 \mathrm{E}+03$ & -2.79 & -0.30 \\
\hline $\mathrm{Pu}-240$ & $1.12 \mathrm{E}+03$ & $1.11 \mathrm{E}+03$ & $1.09 \mathrm{E}+03$ & -2.45 & -0.72 \\
\hline $\mathrm{Pu}-241$ & $6.14 \mathrm{E}+02$ & $5.82 \mathrm{E}+02$ & $4.81 \mathrm{E}+02$ & -21.62 & -5.21 \\
\hline $\mathrm{Pu}-242$ & $8.64 \mathrm{E}+01$ & $8.26 \mathrm{E}+01$ & $6.83 \mathrm{E}+01$ & -20.89 & -4.38 \\
\hline $\mathrm{Am}-241$ & $\mathrm{~N} / \mathrm{A}$ & $\mathrm{N} / \mathrm{A}$ & $9.38 \mathrm{E}+01$ & $\mathrm{~N} / \mathrm{A}$ & $\mathrm{N} / \mathrm{A}$ \\
\hline $\mathrm{Am}-242$ & $\mathrm{~N} / \mathrm{A}$ & $\mathrm{N} / \mathrm{A}$ & $3.88 \mathrm{E}-01$ & $\mathrm{~N} / \mathrm{A}$ & $\mathrm{N} / \mathrm{A}$ \\
\hline $\mathrm{Am}-243$ & $\mathrm{~N} / \mathrm{A}$ & $\mathrm{N} / \mathrm{A}$ & $6.37 \mathrm{E}+00$ & $\mathrm{~N} / \mathrm{A}$ & $\mathrm{N} / \mathrm{A}$ \\
\hline
\end{tabular}

Table 3-31. Trino Vercelles FA 509-032 (Rod E11, AL $=79.2 \mathrm{~cm}$, Burnup $=15.90 \mathrm{GWd} / \mathrm{mtU})$

\begin{tabular}{|c|c|c|c|c|c|}
\hline Isotopes & Measured & SAS2H & GRCASMO3 & $\begin{array}{c}\text { GRCASMO3 } \% \\
\text { Difference }\end{array}$ & $\begin{array}{c}\text { SAS2H \% } \\
\text { Difference }\end{array}$ \\
\hline$U-234$ & N/A & N/A & $2.16 E+02$ & N/A & N/A \\
\hline$U-235$ & $1.66 E+04$ & $1.73 E+04$ & $1.74 E+04$ & 4.73 & 4.15 \\
\hline$U-236$ & $2.74 \mathrm{E}+03$ & $2.68 \mathrm{E}+03$ & $2.67 \mathrm{E}+03$ & -2.68 & -2.15 \\
\hline $\mathrm{U}-238$ & $9.56 \mathrm{E}+05$ & $9.56 \mathrm{E}+05$ & $9.56 \mathrm{E}+05$ & 0.04 & 0.02 \\
\hline $\mathrm{Np}-237$ & $\mathrm{~N} / \mathrm{A}$ & $\mathrm{N} / \mathrm{A}$ & $1.85 \mathrm{E}+02$ & $\mathrm{~N} / \mathrm{A}$ & $\mathrm{N} / \mathrm{A}$ \\
\hline $\mathrm{Pu}-238$ & $\mathrm{~N} / \mathrm{A}$ & $\mathrm{N} / \mathrm{A}$ & $4.19 \mathrm{E}+01$ & $\mathrm{~N} / \mathrm{A}$ & $\mathrm{N} / \mathrm{A}$ \\
\hline $\mathrm{Pu}-239$ & $5.23 \mathrm{E}+03$ & $5.24 \mathrm{E}+03$ & $5.13 \mathrm{E}+03$ & -2.05 & 0.11 \\
\hline $\mathrm{Pu}-240$ & $1.14 \mathrm{E}+03$ & $1.14 \mathrm{E}+03$ & $1.12 \mathrm{E}+03$ & -1.50 & 0.26 \\
\hline $\mathrm{Pu}-241$ & $6.18 \mathrm{E}+02$ & $5.98 \mathrm{E}+02$ & $4.96 \mathrm{E}+02$ & -19.73 & -3.24 \\
\hline $\mathrm{Pu}-242$ & $9.49 \mathrm{E}+01$ & $8.86 \mathrm{E}+01$ & $7.35 \mathrm{E}+01$ & -22.48 & -6.61 \\
\hline $\mathrm{Am}-241$ & $\mathrm{~N} / \mathrm{A}$ & $\mathrm{N} / \mathrm{A}$ & $9.66 \mathrm{E}+01$ & $\mathrm{~N} / \mathrm{A}$ & $\mathrm{N} / \mathrm{A}$ \\
\hline $\mathrm{Am}-242$ & $\mathrm{~N} / \mathrm{A}$ & $\mathrm{N} / \mathrm{A}$ & $3.92 \mathrm{E}-01$ & $\mathrm{~N} / \mathrm{A}$ & $\mathrm{N} / \mathrm{A}$ \\
\hline $\mathrm{Am}-243$ & $\mathrm{~N} / \mathrm{A}$ & $\mathrm{N} / \mathrm{A}$ & $6.97 \mathrm{E}+00$ & $\mathrm{~N} / \mathrm{A}$ & $\mathrm{N} / \mathrm{A}$ \\
\hline
\end{tabular}


Table 3-32. Trino Vercelles FA 509-032 (Rod E11, $A L=26.4 \mathrm{~cm}$, Burnup $=11.53 \mathrm{GWd} / \mathrm{mtU})$

\begin{tabular}{|c|c|c|c|c|c|}
\hline Isotopes & Measured & SAS2H & GRCASMO3 & $\begin{array}{c}\text { GRCASMO3 \% } \\
\text { Difference }\end{array}$ & $\begin{array}{c}\text { SAS2H \% } \\
\text { Difference }\end{array}$ \\
\hline$U-234$ & $\mathrm{~N} / \mathrm{A}$ & $\mathrm{N} / \mathrm{A}$ & $2.33 \mathrm{E}+02$ & $\mathrm{~N} / \mathrm{A}$ & $\mathrm{N} / \mathrm{A}$ \\
\hline $\mathrm{U}-235$ & $2.02 \mathrm{E}+04$ & $2.03 \mathrm{E}+04$ & $2.04 \mathrm{E}+04$ & 1.34 & 0.64 \\
\hline $\mathrm{U}-236$ & $2.50 \mathrm{E}+03$ & $2.15 \mathrm{E}+03$ & $2.13 \mathrm{E}+03$ & -14.86 & -14.07 \\
\hline $\mathrm{U}-238$ & $9.60 \mathrm{E}+05$ & $9.59 \mathrm{E}+05$ & $9.60 \mathrm{E}+05$ & 0.02 & -0.05 \\
\hline $\mathrm{Np}-237$ & $\mathrm{~N} / \mathrm{A}$ & $\mathrm{N} / \mathrm{A}$ & $1.18 \mathrm{E}+02$ & $\mathrm{~N} / \mathrm{A}$ & $\mathrm{N} / \mathrm{A}$ \\
\hline $\mathrm{Pu}-238$ & $\mathrm{~N} / \mathrm{A}$ & $\mathrm{N} / \mathrm{A}$ & $1.85 \mathrm{E}+01$ & $\mathrm{~N} / \mathrm{A}$ & $\mathrm{N} / \mathrm{A}$ \\
\hline $\mathrm{Pu}-239$ & $4.42 \mathrm{E}+03$ & $4.37 \mathrm{E}+03$ & $4.30 \mathrm{E}+03$ & -2.78 & -1.09 \\
\hline $\mathrm{Pu}-240$ & $7.75 \mathrm{E}+02$ & $7.53 \mathrm{E}+02$ & $7.40 \mathrm{E}+02$ & -4.56 & -2.84 \\
\hline $\mathrm{Pu}-241$ & $3.69 \mathrm{E}+02$ & $3.38 \mathrm{E}+02$ & $2.75 \mathrm{E}+02$ & -25.41 & -8.40 \\
\hline $\mathrm{Pu}-242$ & $3.80 \mathrm{E}+01$ & $3.52 \mathrm{E}+01$ & $2.84 \mathrm{E}+01$ & -25.24 & -7.44 \\
\hline $\mathrm{Am}-241$ & $\mathrm{~N} / \mathrm{A}$ & $\mathrm{N} / \mathrm{A}$ & $5.38 \mathrm{E}+01$ & $\mathrm{~N} / \mathrm{A}$ & $\mathrm{N} / \mathrm{A}$ \\
\hline $\mathrm{Am}-242$ & $\mathrm{~N} / \mathrm{A}$ & $\mathrm{N} / \mathrm{A}$ & $2.02 \mathrm{E}-01$ & $\mathrm{~N} / \mathrm{A}$ & $\mathrm{N} / \mathrm{A}$ \\
\hline $\mathrm{Am}-243$ & $\mathrm{~N} / \mathrm{A}$ & $\mathrm{N} / \mathrm{A}$ & $1.86 \mathrm{E}+00$ & $\mathrm{~N} / \mathrm{A}$ & $\mathrm{N} / \mathrm{A}$ \\
\hline
\end{tabular}

Table 3-33. Trino Vercelles FA 509-069 (Rod E11, AL $=237.7 \mathrm{~cm}$, Burnup $=12.86 \mathrm{GWd} / \mathrm{mtU})$

\begin{tabular}{|c|c|c|c|c|c|}
\hline Isotopes & Measured & SAS2H & GRCASMO3 & $\begin{array}{c}\text { GRCASMO3 } \% \\
\text { Difference }\end{array}$ & $\begin{array}{c}\text { SAS2H } \% \\
\text { Difference }\end{array}$ \\
\hline $\mathrm{U}-234$ & $\mathrm{~N} / \mathrm{A}$ & $\mathrm{N} / \mathrm{A}$ & $2.27 \mathrm{E}+02$ & $\mathrm{~N} / \mathrm{A}$ & $\mathrm{N} / \mathrm{A}$ \\
\hline $\mathrm{U}-235$ & $1.95 \mathrm{E}+04$ & $1.99 \mathrm{E}+04$ & $1.95 \mathrm{E}+04$ & 0.45 & 2.26 \\
\hline $\mathrm{U}-236$ & $2.45 \mathrm{E}+03$ & $2.27 \mathrm{E}+03$ & $2.31 \mathrm{E}+03$ & -5.89 & -7.46 \\
\hline $\mathrm{U}-238$ & $9.59 \mathrm{E}+05$ & $9.58 \mathrm{E}+05$ & $9.58 \mathrm{E}+05$ & -0.03 & -0.07 \\
\hline $\mathrm{Np}-237$ & $\mathrm{~N} / \mathrm{A}$ & $\mathrm{N} / \mathrm{A}$ & $1.42 \mathrm{E}+02$ & $\mathrm{~N} / \mathrm{A}$ & $\mathrm{N} / \mathrm{A}$ \\
\hline $\mathrm{Pu}-238$ & $\mathrm{~N} / \mathrm{A}$ & $\mathrm{N} / \mathrm{A}$ & $3.37 \mathrm{E}+01$ & $\mathrm{~N} / \mathrm{A}$ & $\mathrm{N} / \mathrm{A}$ \\
\hline $\mathrm{Pu}-239$ & $4.58 \mathrm{E}+03$ & $4.71 \mathrm{E}+03$ & $4.65 \mathrm{E}+03$ & 1.58 & 2.84 \\
\hline $\mathrm{Pu}-240$ & $8.40 \mathrm{E}+02$ & $8.68 \mathrm{E}+02$ & $8.72 \mathrm{E}+02$ & 3.83 & 3.33 \\
\hline $\mathrm{Pu}-241$ & $4.00 \mathrm{E}+02$ & $3.94 \mathrm{E}+02$ & $3.36 \mathrm{E}+02$ & -16.06 & -1.50 \\
\hline $\mathrm{Pu}-242$ & $4.60 \mathrm{E}+01$ & $4.55 \mathrm{E}+01$ & $3.81 \mathrm{E}+01$ & -17.18 & -1.09 \\
\hline $\mathrm{Am}-241$ & $\mathrm{~N} / \mathrm{A}$ & $\mathrm{N} / \mathrm{A}$ & $8.97 \mathrm{E}+01$ & $\mathrm{~N} / \mathrm{A}$ & $\mathrm{N} / \mathrm{A}$ \\
\hline $\mathrm{Am}-242$ & $\mathrm{~N} / \mathrm{A}$ & $\mathrm{N} / \mathrm{A}$ & $6.52 \mathrm{E}-01$ & $\mathrm{~N} / \mathrm{A}$ & $\mathrm{N} / \mathrm{A}$ \\
\hline $\mathrm{Am}-243$ & $\mathrm{~N} / \mathrm{A}$ & $\mathrm{N} / \mathrm{A}$ & $3.11 \mathrm{E}+00$ & $\mathrm{~N} / \mathrm{A}$ & $\mathrm{N} / \mathrm{A}$ \\
\hline
\end{tabular}

Table 3-34. Trino Vercelles FA 509-069 (Rod E11, AL $=211.3 \mathrm{~cm}$, Burnup $=20.6 \mathrm{GWd} / \mathrm{mtU})$

\begin{tabular}{|c|c|c|c|c|c|}
\hline Isotopes & Measured & SAS2H & GRCASMO3 & $\begin{array}{c}\text { GRCASMO3 } \% \\
\text { Difference }\end{array}$ & $\begin{array}{c}\text { SAS2H \% } \\
\text { Difference }\end{array}$ \\
\hline$U-234$ & $\mathrm{~N} / \mathrm{A}$ & $\mathrm{N} / \mathrm{A}$ & $1.98 \mathrm{E}+02$ & $\mathrm{~N} / \mathrm{A}$ & $\mathrm{N} / \mathrm{A}$ \\
\hline $\mathrm{U}-235$ & $1.44 \mathrm{E}+04$ & $1.51 \mathrm{E}+04$ & $1.46 \mathrm{E}+04$ & 1.85 & 5.15 \\
\hline $\mathrm{U}-236$ & $3.32 \mathrm{E}+03$ & $3.09 \mathrm{E}+03$ & $3.14 \mathrm{E}+03$ & -5.23 & -6.84 \\
\hline $\mathrm{U}-238$ & $9.52 \mathrm{E}+05$ & $9.52 \mathrm{E}+05$ & $9.52 \mathrm{E}+05$ & 0.03 & 0.02 \\
\hline $\mathrm{Np}-237$ & $\mathrm{~N} / \mathrm{A}$ & $\mathrm{N} / \mathrm{A}$ & $2.69 \mathrm{E}+02$ & $\mathrm{~N} / \mathrm{A}$ & $\mathrm{N} / \mathrm{A}$ \\
\hline $\mathrm{Pu}-238$ & $\mathrm{~N} / \mathrm{A}$ & $\mathrm{N} / \mathrm{A}$ & $1.10 \mathrm{E}+02$ & $\mathrm{~N} / \mathrm{A}$ & $\mathrm{N} / \mathrm{A}$ \\
\hline $\mathrm{Pu}-239$ & $5.76 \mathrm{E}+03$ & $5.93 \mathrm{E}+03$ & $5.79 \mathrm{E}+03$ & 0.57 & 3.04 \\
\hline $\mathrm{Pu}-240$ & $1.52 \mathrm{E}+03$ & $1.51 \mathrm{E}+03$ & $1.52 \mathrm{E}+03$ & 0.16 & -0.66 \\
\hline $\mathrm{Pu}-241$ & $8.85 \mathrm{E}+02$ & $8.39 \mathrm{E}+02$ & $7.25 \mathrm{E}+02$ & -18.09 & -5.20 \\
\hline $\mathrm{Pu}-242$ & $1.72 \mathrm{E}+02$ & $1.62 \mathrm{E}+02$ & $1.40 \mathrm{E}+02$ & -18.68 & -5.81 \\
\hline $\mathrm{Am}-241$ & $\mathrm{~N} / \mathrm{A}$ & $\mathrm{N} / \mathrm{A}$ & $1.88 \mathrm{E}+02$ & $\mathrm{~N} / \mathrm{A}$ & $\mathrm{N} / \mathrm{A}$ \\
\hline $\mathrm{Am}-242$ & $\mathrm{~N} / \mathrm{A}$ & $\mathrm{N} / \mathrm{A}$ & $1.45 \mathrm{E}+00$ & $\mathrm{~N} / \mathrm{A}$ & $\mathrm{N} / \mathrm{A}$ \\
\hline $\mathrm{Am}-243$ & $2.39 \mathrm{E}+01$ & $2.32 \mathrm{E}+01$ & $1.90 \mathrm{E}+01$ & -20.54 & -3.09 \\
\hline
\end{tabular}


Table 3-35. Trino Vercelles FA 509-069 (Rod E11, AL $=158.5 \mathrm{~cm}$, Burnup $=23.72 \mathrm{GWd} / \mathrm{mtU})$

\begin{tabular}{|c|c|c|c|c|c|}
\hline Isotopes & Measured & SAS2H & GRCASMO3 & $\begin{array}{c}\text { GRCASMO3 } \% \\
\text { Difference }\end{array}$ & $\begin{array}{c}\text { SAS2H } \% \\
\text { Difference }\end{array}$ \\
\hline$U-234$ & $\mathrm{~N} / \mathrm{A}$ & $\mathrm{N} / \mathrm{A}$ & $1.88 \mathrm{E}+02$ & $\mathrm{~N} / \mathrm{A}$ & $\mathrm{N} / \mathrm{A}$ \\
\hline $\mathrm{U}-235$ & $1.25 \mathrm{E}+04$ & $1.29 \mathrm{E}+04$ & $1.29 \mathrm{E}+04$ & 3.54 & 3.37 \\
\hline $\mathrm{U}-236$ & $3.61 \mathrm{E}+03$ & $3.41 \mathrm{E}+03$ & $3.40 \mathrm{E}+03$ & -5.72 & -5.54 \\
\hline $\mathrm{U}-238$ & $9.49 \mathrm{E}+05$ & $9.49 \mathrm{E}+05$ & $9.49 \mathrm{E}+05$ & 0.02 & -0.03 \\
\hline $\mathrm{Np}-237$ & $\mathrm{~N} / \mathrm{A}$ & $\mathrm{N} / \mathrm{A}$ & $3.22 \mathrm{E}+02$ & $\mathrm{~N} / \mathrm{A}$ & $\mathrm{N} / \mathrm{A}$ \\
\hline $\mathrm{Pu}-238$ & $\mathrm{~N} / \mathrm{A}$ & $\mathrm{N} / \mathrm{A}$ & $1.51 \mathrm{E}+02$ & $\mathrm{~N} / \mathrm{A}$ & $\mathrm{N} / \mathrm{A}$ \\
\hline $\mathrm{Pu}-239$ & $5.90 \mathrm{E}+03$ & $6.22 \mathrm{E}+03$ & $6.04 \mathrm{E}+03$ & 2.48 & 5.51 \\
\hline $\mathrm{Pu}-240$ & $1.76 \mathrm{E}+03$ & $1.78 \mathrm{E}+03$ & $1.75 \mathrm{E}+03$ & -0.26 & 1.42 \\
\hline $\mathrm{Pu}-241$ & $1.03 \mathrm{E}+03$ & $1.03 \mathrm{E}+03$ & $8.78 \mathrm{E}+02$ & -14.79 & 0.00 \\
\hline $\mathrm{Pu}-242$ & $2.44 \mathrm{E}+02$ & $2.40 \mathrm{E}+02$ & $1.99 \mathrm{E}+02$ & -18.35 & -1.44 \\
\hline $\mathrm{Am}-241$ & $\mathrm{~N} / \mathrm{A}$ & $\mathrm{N} / \mathrm{A}$ & $2.22 \mathrm{E}+02$ & $\mathrm{~N} / \mathrm{A}$ & $\mathrm{N} / \mathrm{A}$ \\
\hline $\mathrm{Am}-242$ & $\mathrm{~N} / \mathrm{A}$ & $\mathrm{N} / \mathrm{A}$ & $1.67 \mathrm{E}+00$ & $\mathrm{~N} / \mathrm{A}$ & $\mathrm{N} / \mathrm{A}$ \\
\hline $\mathrm{Am}-243$ & $4.53 \mathrm{E}+01$ & $4.04 \mathrm{E}+01$ & $3.11 \mathrm{E}+01$ & -31.49 & -10.88 \\
\hline
\end{tabular}

Table 3-36. Trino Vercelles FA 509-069 (Rod E11, AL $=79.2 \mathrm{~cm}$, Burnup $=24.30 \mathrm{GWd} / \mathrm{mtU})$

\begin{tabular}{|c|c|c|c|c|c|}
\hline Isotopes & Measured & SAS2H & GRCASMO3 & $\begin{array}{c}\text { GRCASMO3 } \% \\
\text { Difference }\end{array}$ & $\begin{array}{c}\text { SAS2H \% } \\
\text { Difference }\end{array}$ \\
\hline$U-234$ & $\mathrm{~N} / \mathrm{A}$ & $\mathrm{N} / \mathrm{A}$ & $1.87 \mathrm{E}+02$ & $\mathrm{~N} / \mathrm{A}$ & $\mathrm{N} / \mathrm{A}$ \\
\hline $\mathrm{U}-235$ & $1.24 \mathrm{E}+04$ & $1.25 \mathrm{E}+04$ & $1.25 \mathrm{E}+04$ & 1.30 & 1.21 \\
\hline $\mathrm{U}-236$ & $3.64 \mathrm{E}+03$ & $3.46 \mathrm{E}+03$ & $3.45 \mathrm{E}+03$ & -5.19 & -4.89 \\
\hline $\mathrm{U}-238$ & $9.49 \mathrm{E}+05$ & $9.49 \mathrm{E}+05$ & $9.49 \mathrm{E}+05$ & 0.00 & -0.02 \\
\hline $\mathrm{Np}-237$ & $\mathrm{~N} / \mathrm{A}$ & $\mathrm{N} / \mathrm{A}$ & $3.27 \mathrm{E}+02$ & $\mathrm{~N} / \mathrm{A}$ & $\mathrm{N} / \mathrm{A}$ \\
\hline $\mathrm{Pu}-238$ & $\mathrm{~N} / \mathrm{A}$ & $\mathrm{N} / \mathrm{A}$ & $1.55 \mathrm{E}+02$ & $\mathrm{~N} / \mathrm{A}$ & $\mathrm{N} / \mathrm{A}$ \\
\hline $\mathrm{Pu}-239$ & $6.07 \mathrm{E}+03$ & $6.16 \mathrm{E}+03$ & $5.98 \mathrm{E}+03$ & -1.41 & 1.48 \\
\hline $\mathrm{Pu}-240$ & $1.83 \mathrm{E}+03$ & $1.80 \mathrm{E}+03$ & $1.77 \mathrm{E}+03$ & -2.85 & -1.37 \\
\hline $\mathrm{Pu}-241$ & $1.06 \mathrm{E}+03$ & $1.04 \mathrm{E}+03$ & $8.85 \mathrm{E}+02$ & -16.49 & -1.89 \\
\hline $\mathrm{Pu}-242$ & $2.58 \mathrm{E}+02$ & $2.52 \mathrm{E}+02$ & $2.09 \mathrm{E}+02$ & -18.95 & -2.14 \\
\hline $\mathrm{Am}-241$ & $\mathrm{~N} / \mathrm{A}$ & $\mathrm{N} / \mathrm{A}$ & $2.23 \mathrm{E}+02$ & $\mathrm{~N} / \mathrm{A}$ & $\mathrm{N} / \mathrm{A}$ \\
\hline $\mathrm{Am}-242$ & $\mathrm{~N} / \mathrm{A}$ & $\mathrm{N} / \mathrm{A}$ & $1.63 \mathrm{E}+00$ & $\mathrm{~N} / \mathrm{A}$ & $\mathrm{N} / \mathrm{A}$ \\
\hline $\mathrm{Am}-243$ & $4.58 \mathrm{E}+01$ & $4.26 \mathrm{E}+01$ & $3.28 \mathrm{E}+01$ & -28.49 & -7.07 \\
\hline
\end{tabular}

Table 3-37. Trino Vercelles FA 509-069 (Rod E05, $A L=158.5 \mathrm{~cm}$, Burnup $=23.87 \mathrm{GWd} / \mathrm{mtU})$

\begin{tabular}{|c|c|c|c|c|c|}
\hline Isotopes & Measured & SAS2H & GRCASMO3 & $\begin{array}{c}\text { GRCASMO3 } \% \\
\text { Difference }\end{array}$ & $\begin{array}{c}\text { SAS2H \% } \\
\text { Difference }\end{array}$ \\
\hline$U-234$ & $\mathrm{~N} / \mathrm{A}$ & $\mathrm{N} / \mathrm{A}$ & $1.87 \mathrm{E}+02$ & $\mathrm{~N} / \mathrm{A}$ & $\mathrm{N} / \mathrm{A}$ \\
\hline $\mathrm{U}-235$ & $1.29 \mathrm{E}+04$ & $1.28 \mathrm{E}+04$ & $1.29 \mathrm{E}+04$ & -0.31 & -0.85 \\
\hline $\mathrm{U}-236$ & $3.52 \mathrm{E}+03$ & $3.42 \mathrm{E}+03$ & $3.41 \mathrm{E}+03$ & -3.00 & -2.84 \\
\hline $\mathrm{U}-238$ & $9.49 \mathrm{E}+05$ & $9.49 \mathrm{E}+05$ & $9.49 \mathrm{E}+05$ & 0.00 & -0.02 \\
\hline $\mathrm{Np}-237$ & $\mathrm{~N} / \mathrm{A}$ & $\mathrm{N} / \mathrm{A}$ & $3.26 \mathrm{E}+02$ & $\mathrm{~N} / \mathrm{A}$ & $\mathrm{N} / \mathrm{A}$ \\
\hline $\mathrm{Pu}-238$ & $\mathrm{~N} / \mathrm{A}$ & $\mathrm{N} / \mathrm{A}$ & $1.54 \mathrm{E}+02$ & $\mathrm{~N} / \mathrm{A}$ & $\mathrm{N} / \mathrm{A}$ \\
\hline $\mathrm{Pu}-239$ & $5.95 \mathrm{E}+03$ & $6.23 \mathrm{E}+03$ & $6.10 \mathrm{E}+03$ & 2.45 & 4.71 \\
\hline $\mathrm{Pu}-240$ & $1.76 \mathrm{E}+03$ & $1.79 \mathrm{E}+03$ & $1.76 \mathrm{E}+03$ & 0.21 & 1.70 \\
\hline $\mathrm{Pu}-241$ & $1.05 \mathrm{E}+03$ & $1.04 \mathrm{E}+03$ & $8.90 \mathrm{E}+02$ & -15.24 & -0.95 \\
\hline $\mathrm{Pu}-242$ & $2.40 \mathrm{E}+02$ & $2.43 \mathrm{E}+02$ & $2.02 \mathrm{E}+02$ & -15.72 & 1.25 \\
\hline $\mathrm{Am}-241$ & $\mathrm{~N} / \mathrm{A}$ & $\mathrm{N} / \mathrm{A}$ & $2.25 \mathrm{E}+02$ & $\mathrm{~N} / \mathrm{A}$ & $\mathrm{N} / \mathrm{A}$ \\
\hline $\mathrm{Am}-242$ & $\mathrm{~N} / \mathrm{A}$ & $\mathrm{N} / \mathrm{A}$ & $1.70 \mathrm{E}+00$ & $\mathrm{~N} / \mathrm{A}$ & $\mathrm{N} / \mathrm{A}$ \\
\hline $\mathrm{Am}-243$ & $\mathrm{~N} / \mathrm{A}$ & $\mathrm{N} / \mathrm{A}$ & $3.19 \mathrm{E}+01$ & $\mathrm{~N} / \mathrm{A}$ & $\mathrm{N} / \mathrm{A}$ \\
\hline
\end{tabular}


Table 3-38. Trino Vercelles FA 509-069 (Rod E05, AL $=79.2 \mathrm{~cm}$, Burnup $=24.55 \mathrm{GWd} / \mathrm{mtU})$

\begin{tabular}{|c|c|c|c|c|c|}
\hline Isotopes & Measured & SAS2H & GRCASMO3 & $\begin{array}{c}\text { GRCASMO3 \% } \\
\text { Difference }\end{array}$ & $\begin{array}{c}\text { SAS2H \% } \\
\text { Difference }\end{array}$ \\
\hline$U-234$ & $\mathrm{~N} / \mathrm{A}$ & $\mathrm{N} / \mathrm{A}$ & $1.86 \mathrm{E}+02$ & $\mathrm{~N} / \mathrm{A}$ & $\mathrm{N} / \mathrm{A}$ \\
\hline$U-235$ & $1.22 \mathrm{E}+04$ & $1.24 \mathrm{E}+04$ & $1.24 \mathrm{E}+04$ & 1.63 & 1.56 \\
\hline $\mathrm{U}-236$ & $3.54 \mathrm{E}+03$ & $3.47 \mathrm{E}+03$ & $3.47 \mathrm{E}+03$ & -2.03 & -1.98 \\
\hline $\mathrm{U}-238$ & $9.48 \mathrm{E}+05$ & $9.48 \mathrm{E}+05$ & $9.49 \mathrm{E}+05$ & 0.07 & -0.03 \\
\hline $\mathrm{Np}-237$ & $\mathrm{~N} / \mathrm{A}$ & $\mathrm{N} / \mathrm{A}$ & $3.33 \mathrm{E}+02$ & $\mathrm{~N} / \mathrm{A}$ & $\mathrm{N} / \mathrm{A}$ \\
\hline $\mathrm{Pu}-238$ & $\mathrm{~N} / \mathrm{A}$ & $\mathrm{N} / \mathrm{A}$ & $1.60 \mathrm{E}+02$ & $\mathrm{~N} / \mathrm{A}$ & $\mathrm{N} / \mathrm{A}$ \\
\hline $\mathrm{Pu}-239$ & $5.98 \mathrm{E}+03$ & $6.18 \mathrm{E}+03$ & $6.05 \mathrm{E}+03$ & 1.09 & 3.34 \\
\hline $\mathrm{Pu}-240$ & $1.79 \mathrm{E}+03$ & $1.82 \mathrm{E}+03$ & $1.79 \mathrm{E}+03$ & 0.49 & 1.96 \\
\hline $\mathrm{Pu}-241$ & $1.06 \mathrm{E}+03$ & $1.05 \mathrm{E}+03$ & $9.03 \mathrm{E}+02$ & -14.44 & -0.47 \\
\hline $\mathrm{Pu}-242$ & $2.54 \mathrm{E}+02$ & $2.58 \mathrm{E}+02$ & $2.15 \mathrm{E}+02$ & -15.50 & 1.57 \\
\hline $\mathrm{Am}-241$ & $\mathrm{~N} / \mathrm{A}$ & $\mathrm{N} / \mathrm{A}$ & $2.27 \mathrm{E}+02$ & $\mathrm{~N} / \mathrm{A}$ & $\mathrm{N} / \mathrm{A}$ \\
\hline $\mathrm{Am}-242$ & $\mathrm{~N} / \mathrm{A}$ & $\mathrm{N} / \mathrm{A}$ & $1.67 \mathrm{E}+00$ & $\mathrm{~N} / \mathrm{A}$ & $\mathrm{N} / \mathrm{A}$ \\
\hline $\mathrm{Am}-243$ & $4.62 \mathrm{E}+01$ & $4.41 \mathrm{E}+01$ & $3.42 \mathrm{E}+01$ & -25.82 & -4.44 \\
\hline
\end{tabular}

Table 3-39. Trino Vercelles FA 509-069 (Rod L11, AL $=158.5 \mathrm{~cm}$, Burnup $=23.93 \mathrm{GWd} / \mathrm{mtU})$

\begin{tabular}{|c|c|c|c|c|c|}
\hline Isotopes & Measured & SAS2H & GRCASMO3 & $\begin{array}{c}\text { GRCASMO3 } \% \\
\text { Difference }\end{array}$ & $\begin{array}{c}\text { SAS2H \% } \\
\text { Difference }\end{array}$ \\
\hline$U-234$ & $\mathrm{~N} / \mathrm{A}$ & $\mathrm{N} / \mathrm{A}$ & $1.87 \mathrm{E}+02$ & $\mathrm{~N} / \mathrm{A}$ & $\mathrm{N} / \mathrm{A}$ \\
\hline $\mathrm{U}-235$ & $1.28 \mathrm{E}+04$ & $1.28 \mathrm{E}+04$ & $1.28 \mathrm{E}+04$ & 0.16 & -0.16 \\
\hline $\mathrm{U}-236$ & $3.75 \mathrm{E}+03$ & $3.42 \mathrm{E}+03$ & $3.42 \mathrm{E}+03$ & -8.90 & -8.87 \\
\hline $\mathrm{U}-238$ & $9.49 \mathrm{E}+05$ & $9.49 \mathrm{E}+05$ & $9.49 \mathrm{E}+05$ & 0.07 & 0.05 \\
\hline $\mathrm{Np}-237$ & $\mathrm{~N} / \mathrm{A}$ & $\mathrm{N} / \mathrm{A}$ & $3.27 \mathrm{E}+02$ & $\mathrm{~N} / \mathrm{A}$ & $\mathrm{N} / \mathrm{A}$ \\
\hline $\mathrm{Pu}-238$ & $\mathrm{~N} / \mathrm{A}$ & $\mathrm{N} / \mathrm{A}$ & $1.55 \mathrm{E}+02$ & $\mathrm{~N} / \mathrm{A}$ & $\mathrm{N} / \mathrm{A}$ \\
\hline $\mathrm{Pu}-239$ & $6.06 \mathrm{E}+03$ & $6.24 \mathrm{E}+03$ & $6.10 \mathrm{E}+03$ & 0.67 & 2.97 \\
\hline $\mathrm{Pu}-240$ & $1.79 \mathrm{E}+03$ & $1.79 \mathrm{E}+03$ & $1.77 \mathrm{E}+03$ & -1.23 & 0.00 \\
\hline $\mathrm{Pu}-241$ & $1.05 \mathrm{E}+03$ & $1.04 \mathrm{E}+03$ & $8.93 \mathrm{E}+02$ & -14.98 & -0.95 \\
\hline $\mathrm{Pu}-242$ & $2.47 \mathrm{E}+02$ & $2.45 \mathrm{E}+02$ & $2.03 \mathrm{E}+02$ & -17.62 & -0.81 \\
\hline $\mathrm{Am}-241$ & $\mathrm{~N} / \mathrm{A}$ & $\mathrm{N} / \mathrm{A}$ & $2.26 \mathrm{E}+02$ & $\mathrm{~N} / \mathrm{A}$ & $\mathrm{N} / \mathrm{A}$ \\
\hline $\mathrm{Am}-242$ & $\mathrm{~N} / \mathrm{A}$ & $\mathrm{N} / \mathrm{A}$ & $1.71 \mathrm{E}+00$ & $\mathrm{~N} / \mathrm{A}$ & $\mathrm{N} / \mathrm{A}$ \\
\hline $\mathrm{Am}-243$ & $4.45 \mathrm{E}+01$ & $4.16 \mathrm{E}+01$ & $3.22 \mathrm{E}+01$ & -27.64 & -6.56 \\
\hline
\end{tabular}

Table 3-40. Trino Vercelles FA 509-069 (Rod L11, AL $=79.2 \mathrm{~cm}$, Burnup $=24.36 \mathrm{GWd} / \mathrm{mtU})$

\begin{tabular}{|c|c|c|c|c|c|}
\hline Isotopes & Measured & SAS2H & GRCASMO3 & $\begin{array}{c}\text { GRCASMO3 } \% \\
\text { Difference }\end{array}$ & $\begin{array}{c}\text { SAS2H } \% \\
\text { Difference }\end{array}$ \\
\hline$U-234$ & $\mathrm{~N} / \mathrm{A}$ & $\mathrm{N} / \mathrm{A}$ & $1.86 \mathrm{E}+02$ & $\mathrm{~N} / \mathrm{A}$ & $\mathrm{N} / \mathrm{A}$ \\
\hline $\mathrm{U}-235$ & $1.23 \mathrm{E}+04$ & $1.25 \mathrm{E}+04$ & $1.25 \mathrm{E}+04$ & 2.07 & 2.04 \\
\hline $\mathrm{U}-236$ & $3.47 \mathrm{E}+03$ & $3.46 \mathrm{E}+03$ & $3.45 \mathrm{E}+03$ & -0.33 & -0.14 \\
\hline $\mathrm{U}-238$ & $9.48 \mathrm{E}+05$ & $9.49 \mathrm{E}+05$ & $9.49 \mathrm{E}+05$ & 0.10 & 0.08 \\
\hline $\mathrm{Np}-237$ & $\mathrm{~N} / \mathrm{A}$ & $\mathrm{N} / \mathrm{A}$ & $3.30 \mathrm{E}+02$ & $\mathrm{~N} / \mathrm{A}$ & $\mathrm{N} / \mathrm{A}$ \\
\hline $\mathrm{Pu}-238$ & $\mathrm{~N} / \mathrm{A}$ & $\mathrm{N} / \mathrm{A}$ & $1.57 \mathrm{E}+02$ & $\mathrm{~N} / \mathrm{A}$ & $\mathrm{N} / \mathrm{A}$ \\
\hline $\mathrm{Pu}-239$ & $6.00 \mathrm{E}+03$ & $6.16 \mathrm{E}+03$ & $6.03 \mathrm{E}+03$ & 0.60 & 2.75 \\
\hline $\mathrm{Pu}-240$ & $1.81 \mathrm{E}+03$ & $1.81 \mathrm{E}+03$ & $1.78 \mathrm{E}+03$ & -1.67 & 0.00 \\
\hline $\mathrm{Pu}-241$ & $1.06 \mathrm{E}+03$ & $1.04 \mathrm{E}+03$ & $8.94 \mathrm{E}+02$ & -15.30 & -1.42 \\
\hline $\mathrm{Pu}-242$ & $2.59 \mathrm{E}+02$ & $2.53 \mathrm{E}+02$ & $2.10 \mathrm{E}+02$ & -18.73 & -2.32 \\
\hline $\mathrm{Am}-241$ & $\mathrm{~N} / \mathrm{A}$ & $\mathrm{N} / \mathrm{A}$ & $2.25 \mathrm{E}+02$ & $\mathrm{~N} / \mathrm{A}$ & $\mathrm{N} / \mathrm{A}$ \\
\hline $\mathrm{Am}-242$ & $\mathrm{~N} / \mathrm{A}$ & $\mathrm{N} / \mathrm{A}$ & $1.66 \mathrm{E}+00$ & $\mathrm{~N} / \mathrm{A}$ & $\mathrm{N} / \mathrm{A}$ \\
\hline $\mathrm{Am}-243$ & $4.25 \mathrm{E}+01$ & $4.30 \mathrm{E}+01$ & $3.33 \mathrm{E}+01$ & -21.60 & 1.25 \\
\hline
\end{tabular}


Table 3-41. Trino Vercelles FA 509-069 (Rod L05, AL $=158.5 \mathrm{~cm}$, Burnup $=24.33 \mathrm{GWd} / \mathrm{mtU})$

\begin{tabular}{|c|c|c|c|c|c|}
\hline Isotopes & Measured & SAS2H & GRCASMO3 & $\begin{array}{c}\text { GRCASMO3 } \% \\
\text { Difference }\end{array}$ & $\begin{array}{c}\text { SAS2H } \% \\
\text { Difference }\end{array}$ \\
\hline$U-234$ & $\mathrm{~N} / \mathrm{A}$ & $\mathrm{N} / \mathrm{A}$ & $1.86 \mathrm{E}+02$ & $\mathrm{~N} / \mathrm{A}$ & $\mathrm{N} / \mathrm{A}$ \\
\hline$U-235$ & $1.30 \mathrm{E}+04$ & $1.26 \mathrm{E}+04$ & $1.26 \mathrm{E}+04$ & -2.53 & -2.85 \\
\hline$U-236$ & $3.47 \mathrm{E}+03$ & $3.45 \mathrm{E}+03$ & $3.45 \mathrm{E}+03$ & -0.63 & -0.61 \\
\hline$U-238$ & $9.49 \mathrm{E}+05$ & $9.48 \mathrm{E}+05$ & $9.49 \mathrm{E}+05$ & 0.03 & -0.06 \\
\hline $\mathrm{Np}-237$ & $\mathrm{~N} / \mathrm{A}$ & $\mathrm{N} / \mathrm{A}$ & $3.34 \mathrm{E}+02$ & $\mathrm{~N} / \mathrm{A}$ & $\mathrm{N} / \mathrm{A}$ \\
\hline $\mathrm{Pu}-238$ & $\mathrm{~N} / \mathrm{A}$ & $\mathrm{N} / \mathrm{A}$ & $1.61 \mathrm{E}+02$ & $\mathrm{~N} / \mathrm{A}$ & $\mathrm{N} / \mathrm{A}$ \\
\hline $\mathrm{Pu}-239$ & $6.06 \mathrm{E}+03$ & $6.27 \mathrm{E}+03$ & $6.13 \mathrm{E}+03$ & 1.15 & 3.47 \\
\hline $\mathrm{Pu}-240$ & $1.77 \mathrm{E}+03$ & $1.82 \mathrm{E}+03$ & $1.80 \mathrm{E}+03$ & 1.57 & 2.82 \\
\hline $\mathrm{Pu}-241$ & $1.06 \mathrm{E}+03$ & $1.06 \mathrm{E}+03$ & $9.11 \mathrm{E}+02$ & -14.03 & 0.00 \\
\hline $\mathrm{Pu}-242$ & $2.44 \mathrm{E}+02$ & $2.55 \mathrm{E}+02$ & $2.12 \mathrm{E}+02$ & -13.15 & 4.51 \\
\hline $\mathrm{Am}-241$ & $\mathrm{~N} / \mathrm{A}$ & $\mathrm{N} / \mathrm{A}$ & $2.30 \mathrm{E}+02$ & $\mathrm{~N} / \mathrm{A}$ & $\mathrm{N} / \mathrm{A}$ \\
\hline $\mathrm{Am}-242$ & $\mathrm{~N} / \mathrm{A}$ & $\mathrm{N} / \mathrm{A}$ & $1.73 \mathrm{E}+00$ & $\mathrm{~N} / \mathrm{A}$ & $\mathrm{N} / \mathrm{A}$ \\
\hline $\mathrm{Am}-243$ & $\mathrm{~N} / \mathrm{A}$ & $\mathrm{N} / \mathrm{A}$ & $3.41 \mathrm{E}+01$ & $\mathrm{~N} / \mathrm{A}$ & $\mathrm{N} / \mathrm{A}$ \\
\hline
\end{tabular}

Table 3-42. Trino Vercelles FA 509-069 (Rod L05, AL $=79.2 \mathrm{~cm}$, Burnup $=24.31 \mathrm{GWd} / \mathrm{mtU})$

\begin{tabular}{|c|c|c|c|c|c|}
\hline Isotopes & Measured & SAS2H & GRCASMO3 & $\begin{array}{c}\text { GRCASMO3 \% } \\
\text { Difference }\end{array}$ & $\begin{array}{c}\text { SAS2H \% } \\
\text { Difference }\end{array}$ \\
\hline$U-234$ & $\mathrm{~N} / \mathrm{A}$ & $\mathrm{N} / \mathrm{A}$ & $1.86 \mathrm{E}+02$ & $\mathrm{~N} / \mathrm{A}$ & $\mathrm{N} / \mathrm{A}$ \\
\hline $\mathrm{U}-235$ & $1.23 \mathrm{E}+04$ & $1.25 \mathrm{E}+04$ & $1.25 \mathrm{E}+04$ & 1.78 & 1.54 \\
\hline $\mathrm{U}-236$ & $3.57 \mathrm{E}+03$ & $3.46 \mathrm{E}+03$ & $3.45 \mathrm{E}+03$ & -3.35 & -3.05 \\
\hline $\mathrm{U}-238$ & $9.47 \mathrm{E}+05$ & $9.49 \mathrm{E}+05$ & $9.49 \mathrm{E}+05$ & 0.21 & 0.19 \\
\hline $\mathrm{Np}-237$ & $\mathrm{~N} / \mathrm{A}$ & $\mathrm{N} / \mathrm{A}$ & $3.29 \mathrm{E}+02$ & $\mathrm{~N} / \mathrm{A}$ & $\mathrm{N} / \mathrm{A}$ \\
\hline $\mathrm{Pu}-238$ & $\mathrm{~N} / \mathrm{A}$ & $\mathrm{N} / \mathrm{A}$ & $1.56 \mathrm{E}+02$ & $\mathrm{~N} / \mathrm{A}$ & $\mathrm{N} / \mathrm{A}$ \\
\hline $\mathrm{Pu}-239$ & $5.97 \mathrm{E}+03$ & $6.16 \mathrm{E}+03$ & $6.02 \mathrm{E}+03$ & 0.89 & 3.18 \\
\hline $\mathrm{Pu}-240$ & $1.79 \mathrm{E}+03$ & $1.80 \mathrm{E}+03$ & $1.78 \mathrm{E}+03$ & -0.78 & 0.56 \\
\hline $\mathrm{Pu}-241$ & $1.06 \mathrm{E}+03$ & $1.04 \mathrm{E}+03$ & $8.91 \mathrm{E}+02$ & -15.99 & -1.89 \\
\hline $\mathrm{Pu}-242$ & $2.50 \mathrm{E}+02$ & $2.52 \mathrm{E}+02$ & $2.09 \mathrm{E}+02$ & -16.28 & 0.80 \\
\hline $\mathrm{Am}-241$ & $\mathrm{~N} / \mathrm{A}$ & $\mathrm{N} / \mathrm{A}$ & $2.25 \mathrm{E}+02$ & $\mathrm{~N} / \mathrm{A}$ & $\mathrm{N} / \mathrm{A}$ \\
\hline $\mathrm{Am}-242$ & $\mathrm{~N} / \mathrm{A}$ & $\mathrm{N} / \mathrm{A}$ & $1.65 \mathrm{E}+00$ & $\mathrm{~N} / \mathrm{A}$ & $\mathrm{N} / \mathrm{A}$ \\
\hline $\mathrm{Am}-243$ & $\mathrm{~N} / \mathrm{A}$ & $\mathrm{N} / \mathrm{A}$ & $3.30 \mathrm{E}+01$ & $\mathrm{~N} / \mathrm{A}$ & $\mathrm{N} / \mathrm{A}$ \\
\hline
\end{tabular}




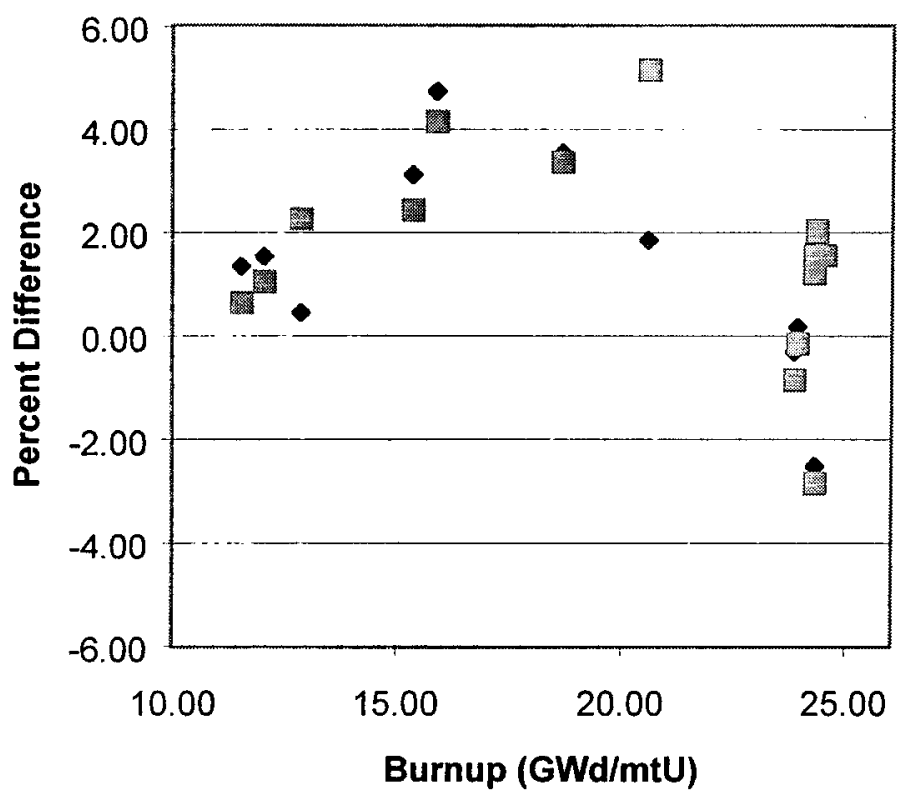

- U-235 GRCASMO3

U-235 SAS2H

Figure 3-12. Trino Vercelles U-235 Comparison

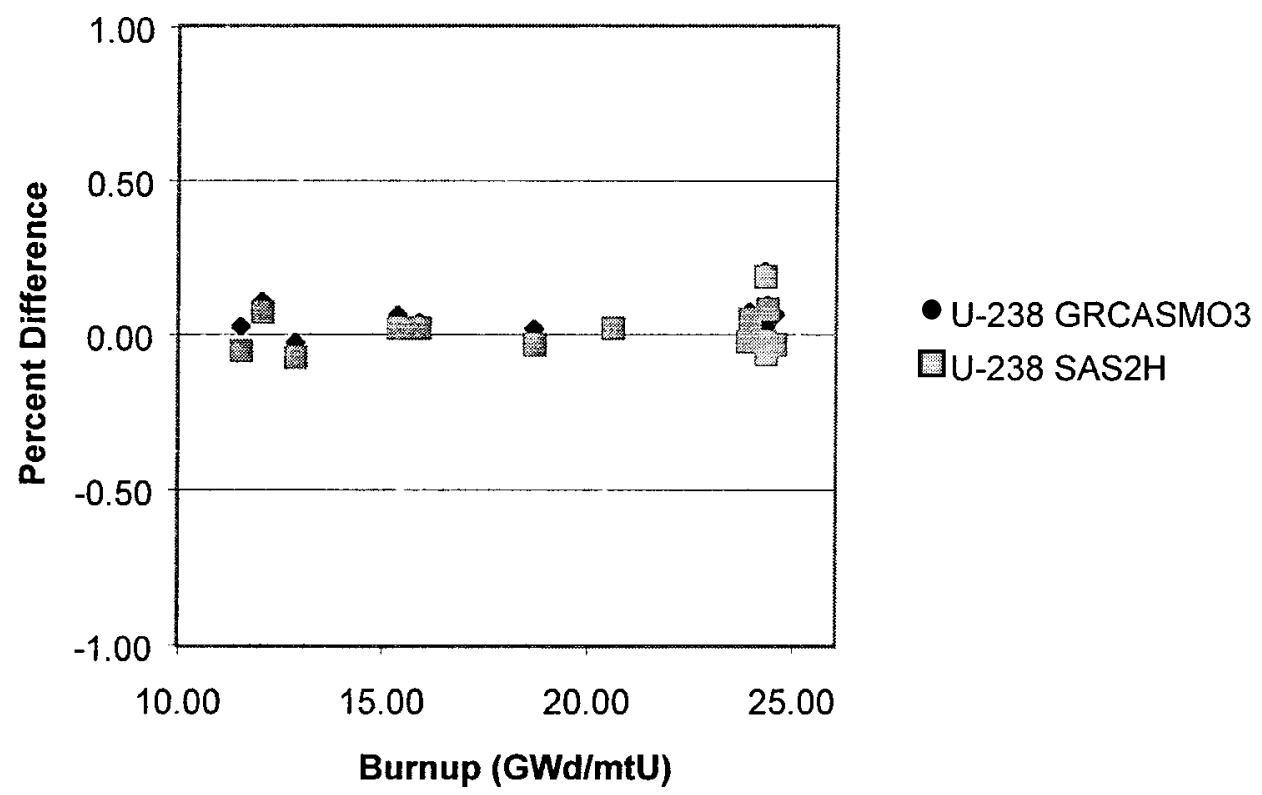

Figure 3-13. Trino Vercelles U-238 Comparison 


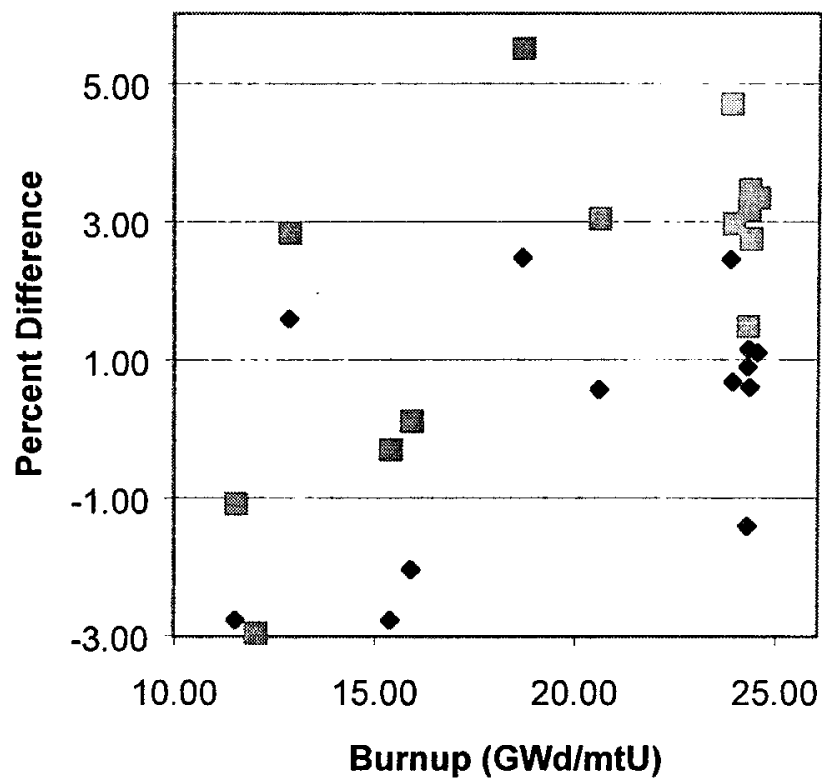

- PU-239 GRCASMO3

圆 Pu-239 SAS2H

Figure 3-14. Trino Vercelles Pu-239 Comparison

\subsubsection{Yankee Rowe}

Tables 3-43 through 3-50 contain the results from the RCAs, the SAS2H calculations, and the GRCASMO3 calculations. The results are presented in both density and percent difference between the calculations (SAS2H and GRCASMO3) and the measured (RCA). Figures 3-15 through 3-17 are plots of the top three contributors to reactivity, U235, U238, and Pu239 for all eight samples from the Yankee Rowe plant.

Table 3-43. Yankee Rowe FA E6-SE-c2 (AL $=57.66 \mathrm{~cm}$, Burnup $=31.41 \mathrm{GWd} / \mathrm{mtU})$

\begin{tabular}{|c|c|c|c|c|c|}
\hline Isotopes & Measured & SAS2H & GRCASMO3 & $\begin{array}{c}\text { GRCASMO3 } \% \\
\text { Difference }\end{array}$ & $\begin{array}{c}\text { SAS2H \% } \\
\text { Difference }\end{array}$ \\
\hline $\mathrm{U}-234$ & $1.15 \mathrm{E}+02$ & $1.22 \mathrm{E}+02$ & $1.18 \mathrm{E}+02$ & 2.40 & 6.09 \\
\hline $\mathrm{U}-235$ & $1.19 \mathrm{E}+04$ & $1.18 \mathrm{E}+04$ & $1.12 \mathrm{E}+04$ & -6.13 & -0.84 \\
\hline $\mathrm{U}-236$ & $4.09 \mathrm{E}+03$ & $4.13 \mathrm{E}+03$ & $4.19 \mathrm{E}+03$ & 2.38 & 0.98 \\
\hline $\mathrm{U}-238$ & $9.36 \mathrm{E}+05$ & $9.40 \mathrm{E}+05$ & $9.40 \mathrm{E}+05$ & 0.47 & 0.43 \\
\hline $\mathrm{Np}-237$ & & & $4.72 \mathrm{E}+02$ & & \\
\hline $\mathrm{Pu}-238$ & $2.11 \mathrm{E}+02$ & $1.86 \mathrm{E}+02$ & $2.59 \mathrm{E}+02$ & 22.69 & -11.85 \\
\hline $\mathrm{Pu}-239$ & $7.68 \mathrm{E}+03$ & $6.52 \mathrm{E}+03$ & $6.92 \mathrm{E}+03$ & -9.92 & -15.10 \\
\hline $\mathrm{Pu}-240$ & $2.27 \mathrm{E}+03$ & $2.42 \mathrm{E}+03$ & $2.22 \mathrm{E}+03$ & -2.20 & 6.61 \\
\hline $\mathrm{Pu}-241$ & $1.58 \mathrm{E}+03$ & $1.56 \mathrm{E}+03$ & $1.16 \mathrm{E}+03$ & -26.30 & -1.27 \\
\hline $\mathrm{Pu}-242$ & $4.00 \mathrm{E}+02$ & $4.55 \mathrm{E}+02$ & $3.51 \mathrm{E}+02$ & -12.32 & 13.75 \\
\hline
\end{tabular}

Table 3-44. Yankee Rowe FA E6-SE-c2 $(\mathrm{AL}=138.94 \mathrm{~cm}$, Burnup $=32.03 \mathrm{GWd} / \mathrm{mtU})$

\begin{tabular}{|c|c|c|c|c|c|}
\hline Isotopes & Measured & SAS2H & GRCASMO3 & $\begin{array}{c}\text { GRCASMO3 } \% \\
\text { Difference }\end{array}$ & $\begin{array}{c}\text { SAS2H \% } \\
\text { Difference }\end{array}$ \\
\hline$U-234$ & $1.14 \mathrm{E}+02$ & $1.20 \mathrm{E}+02$ & $1.16 \mathrm{E}+02$ & 1.82 & 5.26 \\
\hline$U-235$ & $1.18 \mathrm{E}+04$ & $1.16 \mathrm{E}+04$ & $1.10 \mathrm{E}+04$ & -6.78 & -1.69 \\
\hline$U-236$ & $4.18 \mathrm{E}+03$ & $4.17 \mathrm{E}+03$ & $4.22 \mathrm{E}+03$ & 0.98 & -0.24 \\
\hline$U-238$ & $9.35 \mathrm{E}+05$ & $9.39 \mathrm{E}+05$ & $9.40 \mathrm{E}+05$ & 0.49 & 0.43 \\
\hline
\end{tabular}


Table 3-44. Yankee Rowe FA E6-SE-c2 $(\mathrm{AL}=138.94 \mathrm{~cm}$, Burnup $=32.03 \mathrm{GWd} / \mathrm{mtU})$

\begin{tabular}{|c|c|c|c|c|c|}
\hline Isotopes & Measured & SAS2H & GRCASMO3 & $\begin{array}{c}\text { GRCASMO3 } \% \\
\text { Difference }\end{array}$ & $\begin{array}{c}\text { SAS2H \% } \\
\text { Difference }\end{array}$ \\
\hline $\mathrm{Np}-237$ & & & $4.88 \mathrm{E}+02$ & & \\
\hline $\mathrm{Pu}-238$ & $2.22 \mathrm{E}+02$ & $1.97 \mathrm{E}+02$ & $2.72 \mathrm{E}+02$ & 22.50 & -11.26 \\
\hline $\mathrm{Pu}-239$ & $7.98 \mathrm{E}+03$ & $6.66 \mathrm{E}+03$ & $7.03 \mathrm{E}+03$ & -11.88 & -16.54 \\
\hline $\mathrm{Pu}-240$ & $2.37 \mathrm{E}+03$ & $2.46 \mathrm{E}+03$ & $2.27 \mathrm{E}+03$ & -4.11 & 3.80 \\
\hline $\mathrm{Pu}-241$ & $1.67 \mathrm{E}+03$ & $1.62 \mathrm{E}+03$ & $1.20 \mathrm{E}+03$ & -28.01 & -2.99 \\
\hline $\mathrm{Pu}-242$ & $4.22 \mathrm{E}+02$ & $4.77 \mathrm{E}+02$ & $3.68 \mathrm{E}+02$ & -12.69 & 13.03 \\
\hline
\end{tabular}

Table 3-45. Yankee Rowe FA E6-SE-e4 (AL $=57.66 \mathrm{~cm}$, Burnup $=35.26 \mathrm{GWd} / \mathrm{mtU})$

\begin{tabular}{|c|c|c|c|c|c|}
\hline Isotopes & Measured & SAS2H & GRCASMO3 & $\begin{array}{c}\text { GRCASMO3 \% } \\
\text { Difference }\end{array}$ & $\begin{array}{c}\text { SAS2H \% } \\
\text { Difference }\end{array}$ \\
\hline $\mathrm{U}-234$ & $1.20 \mathrm{E}+02$ & $1.14 \mathrm{E}+02$ & $1.15 \mathrm{E}+02$ & -4.07 & -5.00 \\
\hline $\mathrm{U}-235$ & $9.84 \mathrm{E}+03$ & $1.03 \mathrm{E}+04$ & $8.23 \mathrm{E}+03$ & -16.39 & 4.67 \\
\hline $\mathrm{U}-236$ & $4.44 \mathrm{E}+03$ & $4.33 \mathrm{E}+03$ & $4.45 \mathrm{E}+03$ & 0.18 & -2.48 \\
\hline $\mathrm{U}-238$ & $9.34 \mathrm{E}+05$ & $9.36 \mathrm{E}+05$ & $9.40 \mathrm{E}+05$ & 0.69 & 0.21 \\
\hline $\mathrm{Np}-237$ & & & $4.59 \mathrm{E}+02$ & & \\
\hline $\mathrm{Pu}-238$ & $2.40 \mathrm{E}+02$ & $2.38 \mathrm{E}+02$ & $2.65 \mathrm{E}+02$ & 10.25 & -0.83 \\
\hline $\mathrm{Pu}-239$ & $6.82 \mathrm{E}+03$ & $6.71 \mathrm{E}+03$ & $5.46 \mathrm{E}+03$ & -19.90 & -1.61 \\
\hline $\mathrm{Pu}-240$ & $2.48 \mathrm{E}+03$ & $2.65 \mathrm{E}+03$ & $2.26 \mathrm{E}+03$ & -8.86 & 6.85 \\
\hline $\mathrm{Pu}-241$ & $1.62 \mathrm{E}+03$ & $1.76 \mathrm{E}+03$ & $1.03 \mathrm{E}+03$ & -36.23 & 8.64 \\
\hline $\mathrm{Pu}-242$ & $5.29 \mathrm{E}+02$ & $5.78 \mathrm{E}+02$ & $4.66 \mathrm{E}+02$ & -11.82 & 9.26 \\
\hline
\end{tabular}

Table 3-46. Yankee Rowe FA E6-SE-e4 ( $\mathrm{AL}=138.94 \mathrm{~cm}$, Burnup $=35.97 \mathrm{GWd} / \mathrm{mtU})$

\begin{tabular}{|c|c|c|c|c|c|}
\hline Isotopes & Measured & SAS2H & GRCASMO3 & $\begin{array}{c}\text { GRCASMO3 \% } \\
\text { Difference }\end{array}$ & $\begin{array}{c}\text { SAS2H \% } \\
\text { Difference }\end{array}$ \\
\hline $\mathrm{U}-234$ & $1.18 \mathrm{E}+02$ & $1.13 \mathrm{E}+02$ & $1.13 \mathrm{E}+02$ & -3.97 & -4.24 \\
\hline $\mathrm{U}-235$ & $9.78 \mathrm{E}+03$ & $1.02 \mathrm{E}+04$ & $8.05 \mathrm{E}+03$ & -17.69 & 4.29 \\
\hline $\mathrm{U}-236$ & $4.45 \mathrm{E}+03$ & $4.36 \mathrm{E}+03$ & $4.48 \mathrm{E}+03$ & 0.62 & -2.02 \\
\hline $\mathrm{U}-238$ & $9.33 \mathrm{E}+05$ & $9.35 \mathrm{E}+05$ & $9.40 \mathrm{E}+05$ & 0.71 & 0.21 \\
\hline $\mathrm{Np}-237$ & & & $4.74 \mathrm{E}+02$ & & \\
\hline $\mathrm{Pu}-238$ & $2.47 \mathrm{E}+02$ & $2.51 \mathrm{E}+02$ & $2.75 \mathrm{E}+02$ & 11.38 & 1.62 \\
\hline $\mathrm{Pu}-239$ & $6.95 \mathrm{E}+03$ & $6.87 \mathrm{E}+03$ & $5.54 \mathrm{E}+03$ & -20.35 & -1.15 \\
\hline $\mathrm{Pu}-240$ & $2.57 \mathrm{E}+03$ & $2.70 \mathrm{E}+03$ & $2.31 \mathrm{E}+03$ & -10.00 & 5.06 \\
\hline $\mathrm{Pu}-241$ & $1.68 \mathrm{E}+03$ & $1.82 \mathrm{E}+03$ & $1.06 \mathrm{E}+03$ & -36.79 & 8.33 \\
\hline $\mathrm{Pu}-242$ & $5.52 \mathrm{E}+02$ & $6.04 \mathrm{E}+02$ & $4.92 \mathrm{E}+02$ & -10.80 & 9.42 \\
\hline
\end{tabular}

Table 3-47. Yankee Rowe FA E6-C-f6 $(\mathrm{AL}=17.02 \mathrm{~cm}$, Burnup $=20.19 \mathrm{GWd} / \mathrm{mtU})$

\begin{tabular}{|c|c|c|c|c|c|}
\hline Isotopes & Measured & SAS2H & GRCASMO3 & $\begin{array}{c}\text { GRCASMO3 } \% \\
\text { Difference }\end{array}$ & $\begin{array}{c}\text { SAS2H \% } \\
\text { Difference }\end{array}$ \\
\hline $\mathrm{U}-234$ & $1.44 \mathrm{E}+02$ & $1.45 \mathrm{E}+02$ & $1.42 \mathrm{E}+02$ & -1.26 & 0.69 \\
\hline $\mathrm{U}-235$ & $1.72 \mathrm{E}+04$ & $1.71 \mathrm{E}+04$ & $1.71 \mathrm{E}+04$ & -0.42 & -0.58 \\
\hline $\mathrm{U}-236$ & $3.30 \mathrm{E}+03$ & $3.29 \mathrm{E}+03$ & $3.32 \mathrm{E}+03$ & 0.50 & -0.30 \\
\hline $\mathrm{U}-238$ & $9.36 \mathrm{E}+05$ & $9.50 \mathrm{E}+05$ & $9.49 \mathrm{E}+05$ & 1.42 & 1.50 \\
\hline $\mathrm{Np}-237$ & & & $2.82 \mathrm{E}+02$ & & \\
\hline $\mathrm{Pu}-238$ & $7.91 \mathrm{E}+01$ & $6.66 \mathrm{E}+01$ & $9.81 \mathrm{E}+01$ & 23.96 & -15.80 \\
\hline $\mathrm{Pu}-239$ & $6.60 \mathrm{E}+03$ & $5.67 \mathrm{E}+03$ & $6.42 \mathrm{E}+03$ & -2.80 & -14.09 \\
\hline $\mathrm{Pu}-240$ & $1.44 \mathrm{E}+03$ & $1.55 \mathrm{E}+03$ & $1.44 \mathrm{E}+03$ & 0.09 & 7.64 \\
\hline $\mathrm{Pu}-241$ & $9.15 \mathrm{E}+02$ & $8.81 \mathrm{E}+02$ & $6.92 \mathrm{E}+02$ & -24.33 & -3.72 \\
\hline $\mathrm{Pu}-242$ & $1.45 \mathrm{E}+02$ & $1.60 \mathrm{E}+02$ & $1.20 \mathrm{E}+02$ & -17.39 & 10.34 \\
\hline
\end{tabular}


Table 3-48. Yankee Rowe FA E6-C-f6 (AL $=57.66 \mathrm{~cm}$, Burnup $=31.33 \mathrm{GWd} / \mathrm{mtU}$ )

\begin{tabular}{|c|c|c|c|c|c|}
\hline Isotopes & Measured & SAS2H & GRCASMO3 & $\begin{array}{c}\text { GRCASMO3 \% } \\
\text { Difference }\end{array}$ & $\begin{array}{c}\text { SAS2H \% } \\
\text { Difference }\end{array}$ \\
\hline$U-234$ & $1.19 \mathrm{E}+02$ & $1.22 \mathrm{E}+02$ & $1.15 \mathrm{E}+02$ & -2.97 & 2.52 \\
\hline$U-235$ & $1.19 \mathrm{E}+04$ & $1.18 \mathrm{E}+04$ & $1.16 \mathrm{E}+04$ & -2.27 & -0.84 \\
\hline $\mathrm{U}-236$ & $4.15 \mathrm{E}+03$ & $4.13 \mathrm{E}+03$ & $4.17 \mathrm{E}+03$ & 0.50 & -0.48 \\
\hline $\mathrm{U}-238$ & $9.35 \mathrm{E}+05$ & $9.40 \mathrm{E}+05$ & $9.39 \mathrm{E}+05$ & 0.44 & 0.53 \\
\hline $\mathrm{Np}-237$ & & & $5.02 \mathrm{E}+02$ & & \\
\hline $\mathrm{Pu}-238$ & $2.14 \mathrm{E}+02$ & $1.85 \mathrm{E}+02$ & $2.74 \mathrm{E}+02$ & 27.88 & -13.55 \\
\hline $\mathrm{Pu}-239$ & $8.01 \mathrm{E}+03$ & $6.52 \mathrm{E}+03$ & $7.63 \mathrm{E}+03$ & -4.73 & -18.60 \\
\hline $\mathrm{Pu}-240$ & $2.26 \mathrm{E}+03$ & $2.41 \mathrm{E}+03$ & $2.26 \mathrm{E}+03$ & 0.17 & 6.64 \\
\hline $\mathrm{Pu}-241$ & $1.64 \mathrm{E}+03$ & $1.56 \mathrm{E}+03$ & $1.25 \mathrm{E}+03$ & -23.61 & -4.88 \\
\hline $\mathrm{Pu}-242$ & $3.98 \mathrm{E}+02$ & $4.53 \mathrm{E}+02$ & $3.47 \mathrm{E}+02$ & -12.75 & 13.82 \\
\hline
\end{tabular}

Table 3-49. Yankee Rowe FA E6-C-f6 (AL $=138.94 \mathrm{~cm}$, Burnup $=30.39 \mathrm{GWd} / \mathrm{mtU})$

\begin{tabular}{|c|c|c|c|c|c|}
\hline Isotopes & Measured & SAS2H & GRCASMO3 & $\begin{array}{c}\text { GRCASMO3 } \% \\
\text { Difference }\end{array}$ & $\begin{array}{c}\text { SAS2H \% } \\
\text { Difference }\end{array}$ \\
\hline $\mathrm{U}-234$ & $1.42 \mathrm{E}+02$ & $1.25 \mathrm{E}+02$ & $1.17 \mathrm{E}+02$ & -17.44 & -11.97 \\
\hline $\mathrm{U}-235$ & $1.26 \mathrm{E}+04$ & $1.23 \mathrm{E}+04$ & $1.21 \mathrm{E}+04$ & -3.84 & -2.38 \\
\hline $\mathrm{U}-236$ & $4.08 \mathrm{E}+03$ & $4.07 \mathrm{E}+03$ & $4.11 \mathrm{E}+03$ & 0.85 & -0.25 \\
\hline $\mathrm{U}-238$ & $9.37 \mathrm{E}+05$ & $9.40 \mathrm{E}+05$ & $9.40 \mathrm{E}+05$ & 0.29 & 0.32 \\
\hline $\mathrm{Np}-237$ & & & $4.87 \mathrm{E}+02$ & & \\
\hline $\mathrm{Pu}-238$ & $1.76 \mathrm{E}+02$ & $1.79 \mathrm{E}+02$ & $2.56 \mathrm{E}+02$ & 45.66 & 1.70 \\
\hline $\mathrm{Pu}-239$ & $7.87 \mathrm{E}+03$ & $6.57 \mathrm{E}+03$ & $7.66 \mathrm{E}+03$ & -2.71 & -16.52 \\
\hline $\mathrm{Pu}-240$ & $2.12 \mathrm{E}+03$ & $2.36 \mathrm{E}+03$ & $2.22 \mathrm{E}+03$ & 4.61 & 11.32 \\
\hline $\mathrm{Pu}-241$ & $1.54 \mathrm{E}+03$ & $1.53 \mathrm{E}+03$ & $1.15 \mathrm{E}+03$ & -25.05 & -0.65 \\
\hline $\mathrm{Pu}-242$ & $3.46 \mathrm{E}+02$ & $4.27 \mathrm{E}+02$ & $3.26 \mathrm{E}+02$ & -5.88 & 23.41 \\
\hline
\end{tabular}

Table 3-50. Yankee Rowe FA E6-C-f6 (AL $=220.22 \mathrm{~cm}$, Burnup $=15.95 \mathrm{GWd} / \mathrm{mtU}$ )

\begin{tabular}{|c|c|c|c|c|c|}
\hline Isotopes & Measured & SAS2H & GRCASMO3 & $\begin{array}{c}\text { GRCASMO3 } \% \\
\text { Difference }\end{array}$ & $\begin{array}{c}\text { SAS2H \% } \\
\text { Difference }\end{array}$ \\
\hline$U-234$ & $1.55 \mathrm{E}+02$ & $1.54 \mathrm{E}+02$ & $1.53 \mathrm{E}+02$ & -1.51 & -0.65 \\
\hline $\mathrm{U}-235$ & $1.98 \mathrm{E}+04$ & $1.98 \mathrm{E}+04$ & $1.99 \mathrm{E}+04$ & 0.53 & 0.00 \\
\hline $\mathrm{U}-236$ & $2.88 \mathrm{E}+03$ & $2.85 \mathrm{E}+03$ & $2.86 \mathrm{E}+03$ & -0.67 & -1.04 \\
\hline $\mathrm{U}-238$ & $9.49 \mathrm{E}+05$ & $9.53 \mathrm{E}+05$ & $9.53 \mathrm{E}+05$ & 0.39 & 0.42 \\
\hline $\mathrm{Np}-237$ & & & $2.10 \mathrm{E}+02$ & & \\
\hline $\mathrm{Pu}-238$ & $4.70 \mathrm{E}+01$ & $3.84 \mathrm{E}+01$ & $5.49 \mathrm{E}+01$ & 16.88 & -18.30 \\
\hline $\mathrm{Pu}-239$ & $5.95 \mathrm{E}+03$ & $5.36 \mathrm{E}+03$ & $5.85 \mathrm{E}+03$ & -1.74 & -9.92 \\
\hline $\mathrm{Pu}-240$ & $1.12 \mathrm{E}+03$ & $1.18 \mathrm{E}+03$ & $1.11 \mathrm{E}+03$ & -0.98 & 5.36 \\
\hline $\mathrm{Pu}-241$ & $6.63 \mathrm{E}+02$ & $6.24 \mathrm{E}+02$ & $5.01 \mathrm{E}+02$ & -24.50 & -5.88 \\
\hline $\mathrm{Pu}-242$ & $8.03 \mathrm{E}+01$ & $8.31 \mathrm{E}+01$ & $6.57 \mathrm{E}+01$ & -18.19 & 3.49 \\
\hline
\end{tabular}




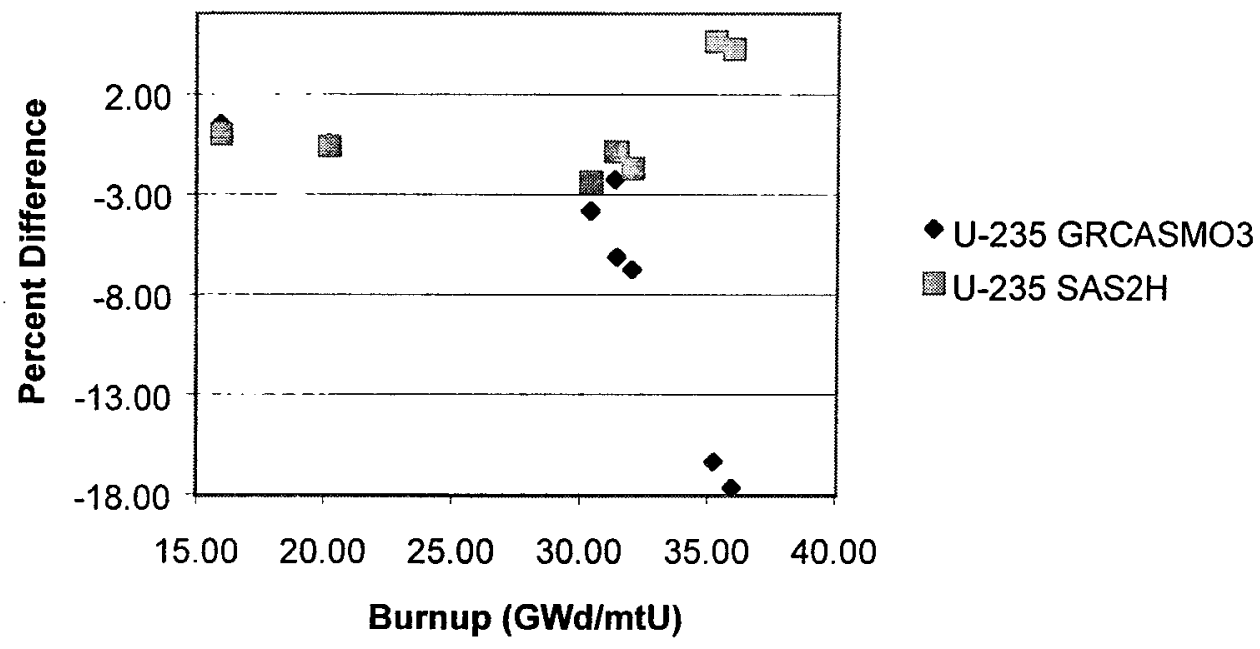

Figure 3-15. Yankee Rowe U-235 Comparison

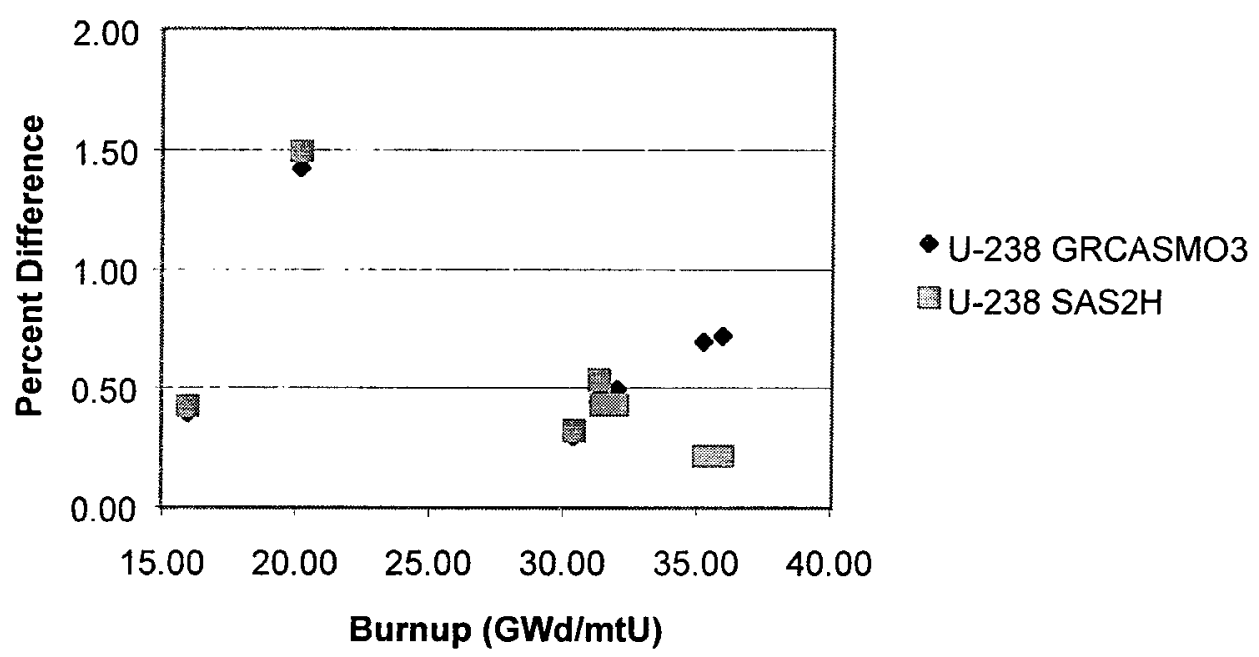

Figure 3-16. Yankee Rowe U-238 Comparison 


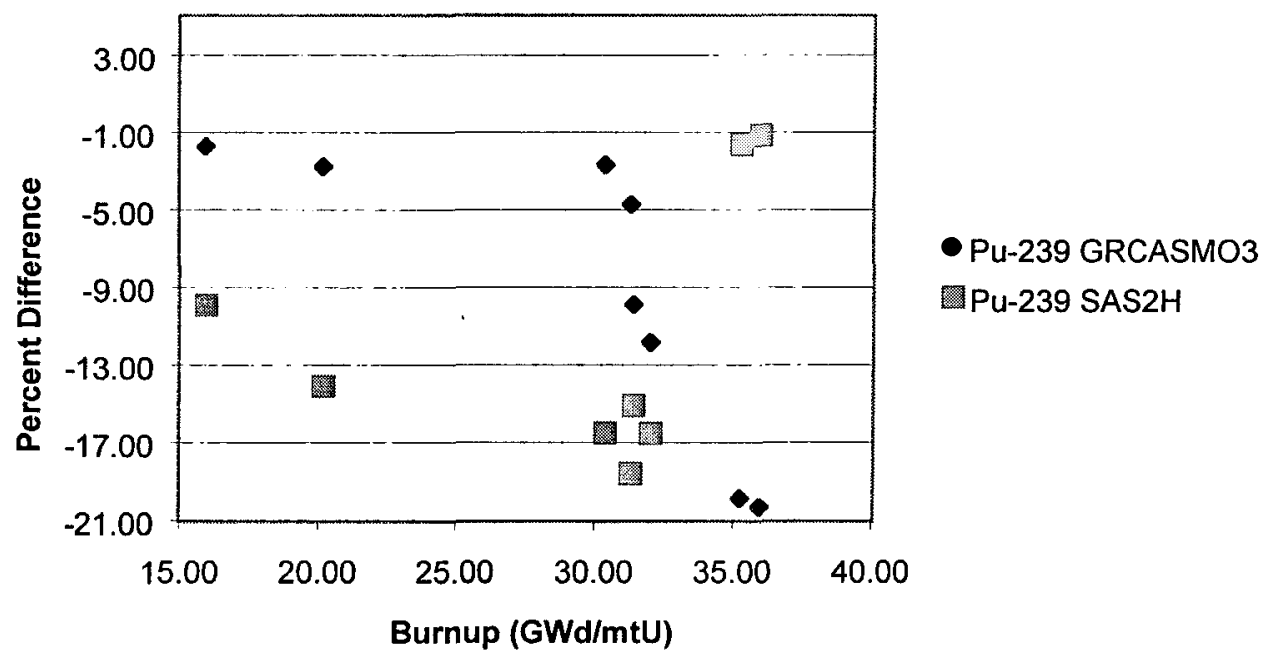

Figure 3-17. Yankee Rowe Pu-239 Comparison

\subsubsection{Turkey Point}

Tables 3-51 through 3-55 contain the results from the RCAs, the SAS2H calculations, and the GRCASMO3 calculations. The results are presented in both density and percent difference between the calculations (SAS2H and GRCASMO3) and the measured (RCA). Figures 3-18 through 3-20 are plots of the top three contributors to reactivity, U235, U238, and Pu239 for all five samples from the Turkey Point plant.

Table 3-51. Turkey Point FA D01 (Rod G09, Burnup = 30.72 GWd/mtU)

\begin{tabular}{|c|c|c|c|c|c|}
\hline Isotopes & Measured & SAS2H & GRCASMO3 & $\begin{array}{c}\text { GRCASMO3 } \% \\
\text { Difference }\end{array}$ & $\begin{array}{c}\text { SAS2H \% } \\
\text { Difference }\end{array}$ \\
\hline $\mathrm{U}-234$ & $1.32 \mathrm{E}+02$ & $1.34 \mathrm{E}+02$ & $1.33 \mathrm{E}+02$ & 0.39 & 1.44 \\
\hline $\mathrm{U}-235$ & $5.87 \mathrm{E}+03$ & $5.55 \mathrm{E}+03$ & $5.51 \mathrm{E}+03$ & -5.98 & -5.37 \\
\hline $\mathrm{U}-236$ & $3.25 \mathrm{E}+03$ & $3.35 \mathrm{E}+03$ & $3.35 \mathrm{E}+03$ & 3.05 & 2.95 \\
\hline $\mathrm{U}-238$ & $9.50 \mathrm{E}+05$ & $9.49 \mathrm{E}+05$ & $9.50 \mathrm{E}+05$ & -0.04 & -0.13 \\
\hline $\mathrm{Np}-237$ & & & $3.70 \mathrm{E}+02$ & & \\
\hline $\mathrm{Pu}-238$ & $1.37 \mathrm{E}+02$ & $1.35 \mathrm{E}+02$ & $2.04 \mathrm{E}+02$ & 49.48 & -1.10 \\
\hline $\mathrm{Pu}-239$ & $4.84 \mathrm{E}+03$ & $5.05 \mathrm{E}+03$ & $4.87 \mathrm{E}+03$ & 0.59 & 4.38 \\
\hline $\mathrm{Pu}-240$ & $2.27 \mathrm{E}+03$ & $2.34 \mathrm{E}+03$ & $2.30 \mathrm{E}+03$ & 1.41 & 3.27 \\
\hline $\mathrm{Pu}-241$ & $1.06 \mathrm{E}+03$ & $1.07 \mathrm{E}+03$ & $9.22 \mathrm{E}+02$ & -13.12 & 0.85 \\
\hline $\mathrm{Pu}-242$ & $5.02 \mathrm{E}+02$ & $5.45 \mathrm{E}+02$ & $4.80 \mathrm{E}+02$ & -4.48 & 8.57 \\
\hline
\end{tabular}

Table 3-52. Turkey Point FA D01 (Rod G10, Burnup $=30.51 \mathrm{GWd} / \mathrm{mtU})$

\begin{tabular}{|c|c|c|c|c|c|}
\hline Isotopes & Measured & SAS2H & GRCASMO3 & $\begin{array}{c}\text { GRCASMO3 \% } \\
\text { Difference }\end{array}$ & $\begin{array}{c}\text { SAS2H \% } \\
\text { Difference }\end{array}$ \\
\hline $\mathrm{U}-234$ & $1.32 \mathrm{E}+02$ & $1.35 \mathrm{E}+02$ & $1.33 \mathrm{E}+02$ & 0.59 & 2.20 \\
\hline $\mathrm{U}-235$ & $5.68 \mathrm{E}+03$ & $5.61 \mathrm{E}+03$ & $5.55 \mathrm{E}+03$ & -2.18 & -1.16 \\
\hline $\mathrm{U}-236$ & $3.26 \mathrm{E}+03$ & $3.34 \mathrm{E}+03$ & $3.35 \mathrm{E}+03$ & 2.92 & 2.61 \\
\hline $\mathrm{U}-238$ & $9.51 \mathrm{E}+05$ & $9.49 \mathrm{E}+05$ & $9.50 \mathrm{E}+05$ & -0.05 & -0.17 \\
\hline $\mathrm{Np}-237$ & & & $3.68 \mathrm{E}+02$ & & \\
\hline $\mathrm{Pu}-238$ & $1.36 \mathrm{E}+02$ & $1.33 \mathrm{E}+02$ & $2.01 \mathrm{E}+02$ & 48.08 & -2.21 \\
\hline $\mathrm{Pu}-239$ & $4.84 \mathrm{E}+03$ & $5.05 \mathrm{E}+03$ & $4.81 \mathrm{E}+03$ & -0.55 & 4.34 \\
\hline $\mathrm{Pu}-240$ & $2.29 \mathrm{E}+03$ & $2.33 \mathrm{E}+03$ & $2.27 \mathrm{E}+03$ & -1.04 & 1.57 \\
\hline
\end{tabular}


Table 3-52. Turkey Point FA D01 (Rod G10, Burnup $=30.51 \mathrm{GWd} / \mathrm{mtU}$ )

\begin{tabular}{|c|c|c|c|c|c|}
\hline Isotopes & Measured & SAS2H & GRCASMO3 & $\begin{array}{c}\text { GRCASMO3 } \% \\
\text { Difference }\end{array}$ & $\begin{array}{c}\text { SAS2H \% } \\
\text { Difference }\end{array}$ \\
\hline $\mathrm{Pu}-241$ & $1.07 \mathrm{E}+03$ & $1.06 \mathrm{E}+03$ & $9.10 \mathrm{E}+02$ & -14.78 & -0.75 \\
\hline $\mathrm{Pu}-242$ & $5.25 \mathrm{E}+02$ & $5.37 \mathrm{E}+02$ & $4.72 \mathrm{E}+02$ & -10.15 & 2.32 \\
\hline
\end{tabular}

Table 3-53. Turkey Point FA D01 (Rod H09, Burnup $=31.56 \mathrm{GWd} / \mathrm{mtU}$ )

\begin{tabular}{|c|c|c|c|c|c|}
\hline Isotopes & Measured & SAS2H & GRCASMO3 & $\begin{array}{c}\text { GRCASMO3 \% } \\
\text { Difference }\end{array}$ & $\begin{array}{c}\text { SAS2H \% } \\
\text { Difference }\end{array}$ \\
\hline $\mathrm{U}-234$ & $1.23 \mathrm{E}+02$ & $1.32 \mathrm{E}+02$ & $1.31 \mathrm{E}+02$ & 6.64 & 7.76 \\
\hline $\mathrm{U}-235$ & $5.58 \mathrm{E}+03$ & $5.29 \mathrm{E}+03$ & $5.18 \mathrm{E}+03$ & -7.19 & -5.27 \\
\hline $\mathrm{U}-236$ & $3.17 \mathrm{E}+03$ & $3.37 \mathrm{E}+03$ & $3.38 \mathrm{E}+03$ & 6.64 & 6.18 \\
\hline $\mathrm{U}-238$ & $9.50 \mathrm{E}+05$ & $9.48 \mathrm{E}+05$ & $9.49 \mathrm{E}+05$ & -0.03 & -0.16 \\
\hline $\mathrm{Np}-237$ & & & $3.78 \mathrm{E}+02$ & & \\
\hline $\mathrm{Pu}-238$ & $1.43 \mathrm{E}+02$ & $1.42 \mathrm{E}+02$ & $2.14 \mathrm{E}+02$ & 49.83 & -0.42 \\
\hline $\mathrm{Pu}-239$ & $4.93 \mathrm{E}+03$ & $5.06 \mathrm{E}+03$ & $4.83 \mathrm{E}+03$ & -2.09 & 2.64 \\
\hline $\mathrm{Pu}-240$ & $2.30 \mathrm{E}+03$ & $2.39 \mathrm{E}+03$ & $2.34 \mathrm{E}+03$ & 1.80 & 4.14 \\
\hline $\mathrm{Pu}-241$ & $1.10 \mathrm{E}+03$ & $1.09 \mathrm{E}+03$ & $9.34 \mathrm{E}+02$ & -15.44 & -1.27 \\
\hline $\mathrm{Pu}-242$ & $5.48 \mathrm{E}+02$ & $5.77 \mathrm{E}+02$ & $5.10 \mathrm{E}+02$ & -6.97 & 5.35 \\
\hline
\end{tabular}

Table 3-54. Turkey Point FA D04 (Rod G09, Burnup = 31.26 GWd/mtU)

\begin{tabular}{|c|c|c|c|c|c|}
\hline Isotopes & Measured & SAS2H & GRCASMO3 & $\begin{array}{c}\text { GRCASMO3 \% } \\
\text { Difference }\end{array}$ & $\begin{array}{c}\text { SAS2H \% } \\
\text { Difference }\end{array}$ \\
\hline$U-234$ & $1.13 \mathrm{E}+02$ & $1.33 \mathrm{E}+02$ & $1.31 \mathrm{E}+02$ & 15.94 & 17.60 \\
\hline $\mathrm{U}-235$ & $5.51 \mathrm{E}+03$ & $5.38 \mathrm{E}+03$ & $5.34 \mathrm{E}+03$ & -2.99 & -2.34 \\
\hline $\mathrm{U}-236$ & $3.16 \mathrm{E}+03$ & $3.36 \mathrm{E}+03$ & $3.37 \mathrm{E}+03$ & 6.85 & 6.46 \\
\hline $\mathrm{U}-238$ & $9.50 \mathrm{E}+05$ & $9.49 \mathrm{E}+05$ & $9.49 \mathrm{E}+05$ & -0.06 & -0.09 \\
\hline $\mathrm{Np}-237$ & & & $3.78 \mathrm{E}+02$ & & \\
\hline $\mathrm{Pu}-238$ & $1.38 \mathrm{E}+02$ & $1.40 \mathrm{E}+02$ & $2.11 \mathrm{E}+02$ & 52.74 & 1.30 \\
\hline $\mathrm{Pu}-239$ & $4.94 \mathrm{E}+03$ & $5.06 \mathrm{E}+03$ & $4.87 \mathrm{E}+03$ & -1.38 & 2.41 \\
\hline $\mathrm{Pu}-240$ & $2.32 \mathrm{E}+03$ & $2.37 \mathrm{E}+03$ & $2.33 \mathrm{E}+03$ & 0.39 & 2.16 \\
\hline $\mathrm{Pu}-241$ & $1.12 \mathrm{E}+03$ & $1.08 \mathrm{E}+03$ & $9.35 \mathrm{E}+02$ & -16.85 & -3.91 \\
\hline $\mathrm{Pu}-242$ & $5.43 \mathrm{E}+02$ & $5.65 \mathrm{E}+02$ & $4.98 \mathrm{E}+02$ & -8.26 & 4.09 \\
\hline
\end{tabular}

Table 3-55. Turkey Point FA D04 (Rod G10, Burnup = $31.31 \mathrm{GWd} / \mathrm{mtU}$ )

\begin{tabular}{|c|c|c|c|c|c|}
\hline Isotopes & Measured & SAS2H & GRCASMO3 & $\begin{array}{c}\text { GRCASMO3 \% } \\
\text { Difference }\end{array}$ & $\begin{array}{c}\text { SAS2H \% } \\
\text { Difference }\end{array}$ \\
\hline $\mathrm{U}-234$ & $1.32 \mathrm{E}+02$ & $1.33 \mathrm{E}+02$ & $1.31 \mathrm{E}+02$ & -1.02 & 0.76 \\
\hline $\mathrm{U}-235$ & $5.66 \mathrm{E}+03$ & $5.37 \mathrm{E}+03$ & $5.30 \mathrm{E}+03$ & -6.43 & -5.16 \\
\hline $\mathrm{U}-236$ & $3.25 \mathrm{E}+03$ & $3.37 \mathrm{E}+03$ & $3.38 \mathrm{E}+03$ & 3.89 & 3.63 \\
\hline $\mathrm{U}-238$ & $9.50 \mathrm{E}+05$ & $9.49 \mathrm{E}+05$ & $9.49 \mathrm{E}+05$ & -0.04 & -0.08 \\
\hline $\mathrm{Np}-237$ & & & $3.79 \mathrm{E}+02$ & & \\
\hline $\mathrm{Pu}-238$ & $1.37 \mathrm{E}+02$ & $1.40 \mathrm{E}+02$ & $2.12 \mathrm{E}+02$ & 54.42 & 2.04 \\
\hline $\mathrm{Pu}-239$ & $4.79 \mathrm{E}+03$ & $5.06 \mathrm{E}+03$ & $4.82 \mathrm{E}+03$ & 0.73 & 5.68 \\
\hline $\mathrm{Pu}-240$ & $2.28 \mathrm{E}+03$ & $2.38 \mathrm{E}+03$ & $2.32 \mathrm{E}+03$ & 1.67 & 4.48 \\
\hline $\mathrm{Pu}-241$ & $1.07 \mathrm{E}+03$ & $1.08 \mathrm{E}+03$ & $9.29 \mathrm{E}+02$ & -13.32 & 0.75 \\
\hline $\mathrm{Pu}-242$ & $5.24 \mathrm{E}+02$ & $5.67 \mathrm{E}+02$ & $4.99 \mathrm{E}+02$ & -4.70 & 8.31 \\
\hline
\end{tabular}




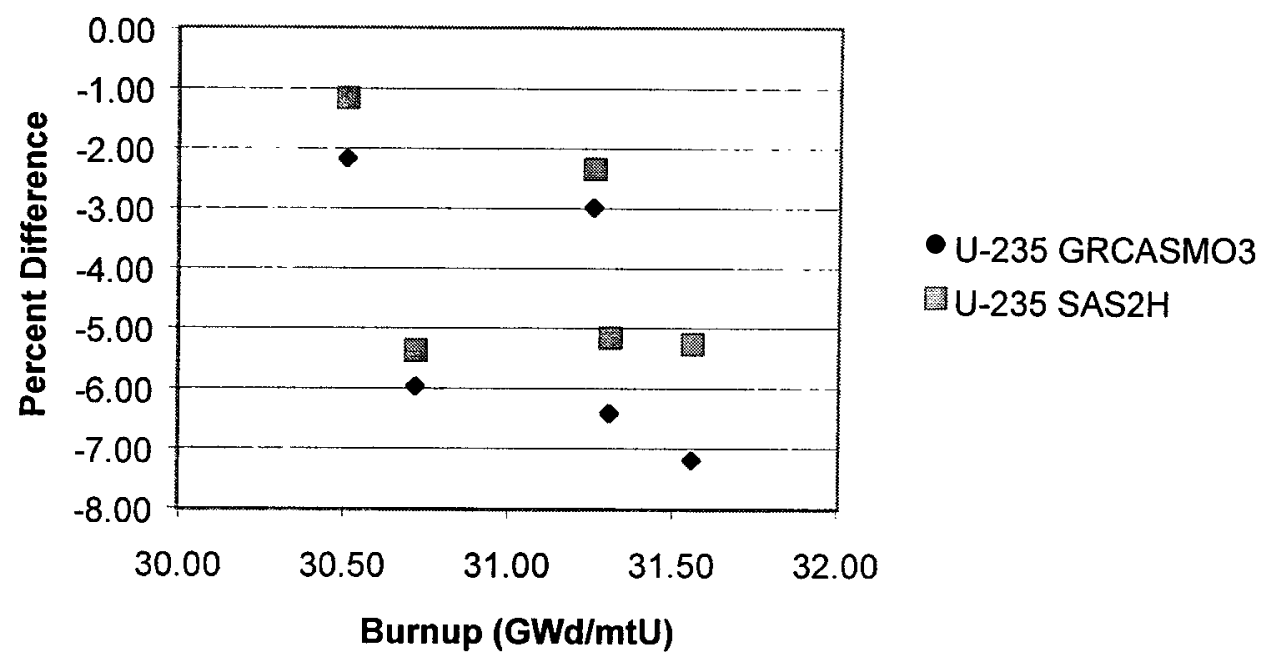

Figure 3-18. Turkey Point U-235 Comparison

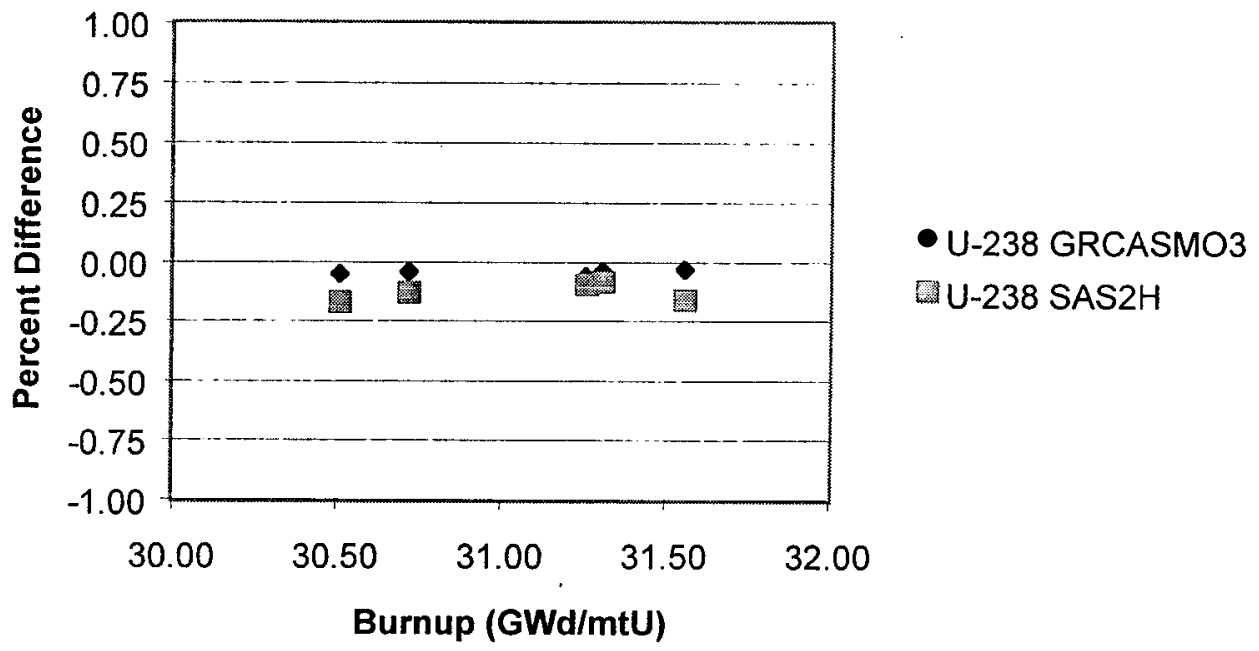

Figure 3-19. Turkey Point U-238 Comparison 


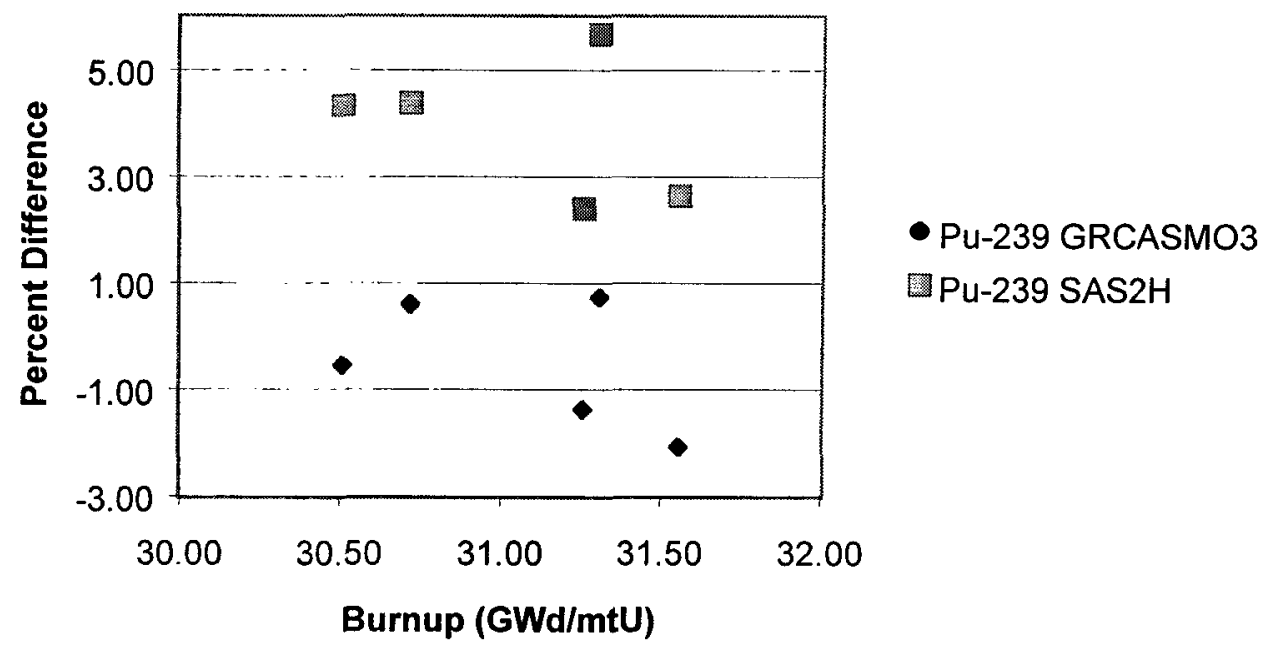

Figure 3-20. Turkey Point Pu-239 Comparison

\subsection{BOILING WATER REACTORS}

\subsubsection{Cooper}

Tables 3-56 through 3-61 contain the results from the RCAs, the SAS2H calculations, and the GRCASMO3 calculations. The results are presented in both density and percent difference between the calculations (SAS2H and GRCASMO3) and the measured (RCA). Figures 3-21 through 3-23 are plots of the top three contributors to reactivity, U235, U238, and Pu239 for all six samples from the Cooper Station.

Table 3-56. Cooper Sample ADD2966-B $\left(A L=55.1 \mathrm{~cm}, \mathrm{VOI}^{\mathrm{a}}=2.59\right.$, Burnup $\left.=18.96 \mathrm{GWd} / \mathrm{mtU}\right)$

\begin{tabular}{|c|c|c|c|c|c|}
\hline Isotopes & Measured & SAS2H & GRCASMO3 & $\begin{array}{c}\text { GRCASMO3 \% } \\
\text { Difference }\end{array}$ & $\begin{array}{c}\text { SAS2H \% } \\
\text { Difference }\end{array}$ \\
\hline$U-234$ & $1.70 \mathrm{E}+02$ & $1.67 \mathrm{E}+02$ & $1.75 \mathrm{E}+02$ & 2.90 & -1.76 \\
\hline $\mathrm{U}-235$ & $1.19 \mathrm{E}+04$ & $1.20 \mathrm{E}+04$ & $1.09 \mathrm{E}+04$ & -8.15 & 0.76 \\
\hline $\mathrm{U}-236$ & $2.63 \mathrm{E}+03$ & $2.61 \mathrm{E}+03$ & $2.61 \mathrm{E}+03$ & -0.84 & -0.76 \\
\hline $\mathrm{U}-238$ & $8.44 \mathrm{E}+05$ & $8.42 \mathrm{E}+05$ & $8.45 \mathrm{E}+05$ & 0.21 & -0.20 \\
\hline $\mathrm{Np}-237$ & $1.58 \mathrm{E}+02$ & $2.00 \mathrm{E}+02$ & $1.47 \mathrm{E}+02$ & -6.57 & 26.95 \\
\hline $\mathrm{Pu}-238$ & $5.35 \mathrm{E}+01$ & $5.93 \mathrm{E}+01$ & $6.62 \mathrm{E}+01$ & 23.72 & 10.84 \\
\hline $\mathrm{Pu}-239$ & $3.74 \mathrm{E}+03$ & $4.41 \mathrm{E}+03$ & $3.14 \mathrm{E}+03$ & -16.12 & 17.98 \\
\hline $\mathrm{Pu}-240$ & $1.22 \mathrm{E}+03$ & $1.30 \mathrm{E}+03$ & $1.14 \mathrm{E}+03$ & -6.83 & 6.56 \\
\hline $\mathrm{Pu}-241$ & $3.04 \mathrm{E}+02$ & $4.28 \mathrm{E}+02$ & $2.09 \mathrm{E}+02$ & -31.17 & 40.78 \\
\hline $\mathrm{Pu}-242$ & $9.89 \mathrm{E}+01$ & $1.22 \mathrm{E}+02$ & $7.80 \mathrm{E}+01$ & -21.20 & 23.33 \\
\hline $\mathrm{Am}-241$ & $1.51 \mathrm{E}+02$ & $2.08 \mathrm{E}+02$ & $2.50 \mathrm{E}+02$ & 65.36 & 37.60 \\
\hline
\end{tabular}

NOTE: ${ }^{a}$ VOI = void percent 
Table 3-57. Cooper Sample ADD2966-K $(A L=218.9 \mathrm{~cm}, \mathrm{VOI}=60.9$, Burnup $=33.07 \mathrm{GWd} / \mathrm{mtU})$

\begin{tabular}{|c|c|c|c|c|c|}
\hline Isotopes & Measured & SAS2H & GRCASMO3 & $\begin{array}{c}\text { GRCASMO3 \% } \\
\text { Difference }\end{array}$ & $\begin{array}{c}\text { SAS2H \% } \\
\text { Difference }\end{array}$ \\
\hline $\mathrm{U}-234$ & $1.35 \mathrm{E}+02$ & $1.39 \mathrm{E}+02$ & $1.25 \mathrm{E}+02$ & -7.21 & 2.96 \\
\hline $\mathrm{U}-235$ & $5.34 \mathrm{E}+03$ & $5.22 \mathrm{E}+03$ & $5.93 \mathrm{E}+03$ & 10.98 & -2.25 \\
\hline $\mathrm{U}-236$ & $3.53 \mathrm{E}+03$ & $3.46 \mathrm{E}+03$ & $3.45 \mathrm{E}+03$ & -2.36 & -1.98 \\
\hline $\mathrm{U}-238$ & $8.35 \mathrm{E}+05$ & $8.34 \mathrm{E}+05$ & $8.33 \mathrm{E}+05$ & -0.21 & -0.07 \\
\hline $\mathrm{Np}-237$ & $3.61 \mathrm{E}+02$ & $3.44 \mathrm{E}+02$ & $3.96 \mathrm{E}+02$ & 9.97 & -4.58 \\
\hline $\mathrm{Pu}-238$ & $1.74 \mathrm{E}+02$ & $1.60 \mathrm{E}+02$ & $3.15 \mathrm{E}+02$ & 80.46 & -8.20 \\
\hline $\mathrm{Pu}-239$ & $3.58 \mathrm{E}+03$ & $3.95 \mathrm{E}+03$ & $4.62 \mathrm{E}+03$ & 29.13 & 10.37 \\
\hline $\mathrm{Pu}-240$ & $2.22 \mathrm{E}+03$ & $2.10 \mathrm{E}+03$ & $2.21 \mathrm{E}+03$ & -0.18 & -5.23 \\
\hline $\mathrm{Pu}-241$ & $6.39 \mathrm{E}+02$ & $6.87 \mathrm{E}+02$ & $5.49 \mathrm{E}+02$ & -14.01 & 7.51 \\
\hline $\mathrm{Pu}-242$ & $4.41 \mathrm{E}+02$ & $4.60 \mathrm{E}+02$ & $3.37 \mathrm{E}+02$ & -23.47 & 4.38 \\
\hline $\mathrm{Am}-241$ & $2.56 \mathrm{E}+02$ & $3.06 \mathrm{E}+02$ & $5.93 \mathrm{E}+02$ & 131.25 & 19.43 \\
\hline
\end{tabular}

Table 3-58. Cooper Sample ADD2966-T (AL $=274.8 \mathrm{~cm}, \mathrm{VOI}=66.56$, Burnup $=33.94 \mathrm{GWd} / \mathrm{mtU})$

\begin{tabular}{|c|c|c|c|c|c|}
\hline Isotopes & Measured & SAS2H & GRCASMO3 & $\begin{array}{c}\text { GRCASMO3 } \% \\
\text { Difference }\end{array}$ & $\begin{array}{c}\text { SAS2H \% } \\
\text { Difference }\end{array}$ \\
\hline$U-234$ & $1.44 \mathrm{E}+02$ & $1.38 \mathrm{E}+02$ & $1.21 \mathrm{E}+02$ & -15.65 & -4.17 \\
\hline $\mathrm{U}-235$ & $4.83 \mathrm{E}+03$ & $4.50 \mathrm{E}+03$ & $5.84 \mathrm{E}+03$ & 20.91 & -6.83 \\
\hline $\mathrm{U}-236$ & $3.62 \mathrm{E}+03$ & $3.51 \mathrm{E}+03$ & $3.47 \mathrm{E}+03$ & -4.02 & -3.04 \\
\hline $\mathrm{U}-238$ & $8.39 \mathrm{E}+05$ & $8.34 \mathrm{E}+05$ & $8.32 \mathrm{E}+05$ & -0.88 & -0.60 \\
\hline $\mathrm{Np}-237$ & $3.49 \mathrm{E}+02$ & $3.32 \mathrm{E}+02$ & $4.21 \mathrm{E}+02$ & 20.46 & -4.91 \\
\hline $\mathrm{Pu}-238$ & $1.71 \mathrm{E}+02$ & $1.54 \mathrm{E}+02$ & $3.41 \mathrm{E}+02$ & 99.82 & -9.73 \\
\hline $\mathrm{Pu}-239$ & $3.34 \mathrm{E}+03$ & $3.57 \mathrm{E}+03$ & $4.87 \mathrm{E}+03$ & 45.85 & 7.01 \\
\hline $\mathrm{Pu}-240$ & $2.19 \mathrm{E}+03$ & $2.08 \mathrm{E}+03$ & $2.30 \mathrm{E}+03$ & 4.91 & -5.02 \\
\hline $\mathrm{Pu}-241$ & $6.20 \mathrm{E}+02$ & $6.44 \mathrm{E}+02$ & $5.79 \mathrm{E}+02$ & -6.64 & 3.85 \\
\hline $\mathrm{Pu}-242$ & $4.74 \mathrm{E}+02$ & $4.91 \mathrm{E}+02$ & $3.50 \mathrm{E}+02$ & -26.04 & 3.65 \\
\hline $\mathrm{Am}-241$ & $2.45 \mathrm{E}+02$ & $2.83 \mathrm{E}+02$ & $6.24 \mathrm{E}+02$ & 155.01 & 15.72 \\
\hline
\end{tabular}

Table 3-59. Cooper Sample ADD2974-B $(\mathrm{AL}=55.7 \mathrm{~cm}, \mathrm{VOI}=2.9$, Burnup $=17.84 \mathrm{GWd} / \mathrm{mtU})$

\begin{tabular}{|c|c|c|c|c|c|}
\hline Isotopes & Measured & SAS2H & GRCASMO3 & $\begin{array}{c}\text { GRCASMO3 } \% \\
\text { Difference }\end{array}$ & $\begin{array}{c}\text { SAS2H \% } \\
\text { Difference }\end{array}$ \\
\hline $\mathrm{U}-234$ & $1.74 \mathrm{E}+02$ & $1.70 \mathrm{E}+02$ & $1.76 \mathrm{E}+02$ & 1.34 & -2.30 \\
\hline $\mathrm{U}-235$ & $1.30 \mathrm{E}+04$ & $1.25 \mathrm{E}+04$ & $1.19 \mathrm{E}+04$ & -8.61 & -3.85 \\
\hline $\mathrm{U}-236$ & $2.48 \mathrm{E}+03$ & $2.52 \mathrm{E}+03$ & $2.49 \mathrm{E}+03$ & 0.47 & 1.61 \\
\hline $\mathrm{U}-238$ & $8.55 \mathrm{E}+05$ & $8.43 \mathrm{E}+05$ & $8.45 \mathrm{E}+05$ & -1.06 & -1.35 \\
\hline $\mathrm{Np}-237$ & $1.55 \mathrm{E}+02$ & $1.85 \mathrm{E}+02$ & $1.47 \mathrm{E}+02$ & -4.70 & 19.58 \\
\hline $\mathrm{Pu}-238$ & $5.21 \mathrm{E}+01$ & $5.15 \mathrm{E}+01$ & $6.25 \mathrm{E}+01$ & 19.92 & -1.15 \\
\hline $\mathrm{Pu}-239$ & $4.06 \mathrm{E}+03$ & $4.32 \mathrm{E}+03$ & $3.36 \mathrm{E}+03$ & -17.26 & 6.51 \\
\hline $\mathrm{Pu}-240$ & $1.18 \mathrm{E}+03$ & $1.21 \mathrm{E}+03$ & $1.10 \mathrm{E}+03$ & -7.39 & 2.20 \\
\hline $\mathrm{Pu}-241$ & $3.42 \mathrm{E}+02$ & $3.93 \mathrm{E}+02$ & $2.06 \mathrm{E}+02$ & -39.74 & 15.08 \\
\hline $\mathrm{Pu}-242$ & $8.74 \mathrm{E}+01$ & $1.05 \mathrm{E}+02$ & $6.77 \mathrm{E}+01$ & -22.53 & 20.11 \\
\hline $\mathrm{Am}-241$ & $1.53 \mathrm{E}+02$ & $1.92 \mathrm{E}+02$ & $2.47 \mathrm{E}+02$ & 62.14 & 25.80 \\
\hline
\end{tabular}

Table 3-60. Cooper Sample ADD2974-J $(\mathrm{AL}=115.0 \mathrm{~cm}, \mathrm{VOI}=29.0$, Burnup $=29.23 \mathrm{GWd} / \mathrm{mtU})$

\begin{tabular}{|c|c|c|c|c|c|}
\hline Isotopes & Measured & SAS2H & GRCASMO3 & $\begin{array}{c}\text { GRCASMO3 } \% \\
\text { Difference }\end{array}$ & $\begin{array}{c}\text { SAS2H } \% \\
\text { Difference }\end{array}$ \\
\hline $\mathrm{U}-234$ & $1.46 \mathrm{E}+02$ & $1.44 \mathrm{E}+02$ & $1.41 \mathrm{E}+02$ & -3.66 & -1.37 \\
\hline $\mathrm{U}-235$ & $7.76 \mathrm{E}+03$ & $7.22 \mathrm{E}+03$ & $6.85 \mathrm{E}+03$ & -11.74 & -6.96 \\
\hline $\mathrm{U}-236$ & $3.36 \mathrm{E}+03$ & $3.29 \mathrm{E}+03$ & $3.28 \mathrm{E}+03$ & -2.29 & -2.08 \\
\hline $\mathrm{U}-238$ & $8.49 \mathrm{E}+05$ & $8.35 \mathrm{E}+05$ & $8.37 \mathrm{E}+05$ & -1.43 & -1.65 \\
\hline $\mathrm{Np}-237$ & $3.34 \mathrm{E}+02$ & $3.29 \mathrm{E}+02$ & $3.11 \mathrm{E}+02$ & -6.64 & -1.36 \\
\hline $\mathrm{Pu}-238$ & $1.64 \mathrm{E}+02$ & $1.44 \mathrm{E}+02$ & $2.23 \mathrm{E}+02$ & 35.88 & -12.20 \\
\hline
\end{tabular}


Table 3-60. Cooper Sample ADD2974-J $(A L=115.0 \mathrm{~cm}, \mathrm{VOI}=29.0$, Burnup $=29.23 \mathrm{GWd} / \mathrm{mtU}$ )

\begin{tabular}{|c|c|c|c|c|c|}
\hline Isotopes & Measured & SAS2H & GRCASMO3 & $\begin{array}{c}\text { GRCASMO3 } \% \\
\text { Difference }\end{array}$ & $\begin{array}{c}\text { SAS2H } \% \\
\text { Difference }\end{array}$ \\
\hline $\mathrm{Pu}-239$ & $4.53 \mathrm{E}+03$ & $4.61 \mathrm{E}+03$ & $4.04 \mathrm{E}+03$ & -10.67 & 1.86 \\
\hline $\mathrm{Pu}-240$ & $2.16 \mathrm{E}+03$ & $1.98 \mathrm{E}+03$ & $1.94 \mathrm{E}+03$ & -10.56 & -8.50 \\
\hline $\mathrm{Pu}-241$ & $6.65 \mathrm{E}+03$ & $6.93 \mathrm{E}+03$ & $4.48 \mathrm{E}+02$ & -93.26 & 4.23 \\
\hline $\mathrm{Pu}-242$ & $3.25 \mathrm{E}+02$ & $3.42 \mathrm{E}+02$ & $2.61 \mathrm{E}+02$ & -19.52 & 5.33 \\
\hline $\mathrm{Am}-241$ & $2.76 \mathrm{E}+02$ & $3.19 \mathrm{E}+02$ & $4.87 \mathrm{E}+02$ & 76.54 & 15.55 \\
\hline
\end{tabular}

Table 3-61. Cooper Sample ADD2974-U $(A L=291.0 \mathrm{~cm}$, VOI $=68.0$, Burnup $=31.04 \mathrm{GWd} / \mathrm{mtU})$

\begin{tabular}{|c|c|c|c|c|c|}
\hline Isotopes & Measured & SAS2H & GRCASMO3 & $\begin{array}{c}\text { GRCASMO3 } \% \\
\text { Difference }\end{array}$ & $\begin{array}{c}\text { SAS2H \% } \\
\text { Difference }\end{array}$ \\
\hline $\mathrm{U}-234$ & $1.54 \mathrm{E}+02$ & $1.45 \mathrm{E}+02$ & $1.27 \mathrm{E}+02$ & -17.35 & -5.84 \\
\hline $\mathrm{U}-235$ & $6.28 \mathrm{E}+03$ & $5.32 \mathrm{E}+03$ & $7.34 \mathrm{E}+03$ & 16.86 & -15.29 \\
\hline $\mathrm{U}-236$ & $3.48 \mathrm{E}+03$ & $3.40 \mathrm{E}+03$ & $3.34 \mathrm{E}+03$ & -3.90 & -2.30 \\
\hline $\mathrm{U}-238$ & $8.46 \mathrm{E}+05$ & $8.37 \mathrm{E}+05$ & $8.33 \mathrm{E}+05$ & -1.53 & -1.01 \\
\hline $\mathrm{Np}-237$ & $3.35 \mathrm{E}+02$ & $2.93 \mathrm{E}+02$ & $4.04 \mathrm{E}+02$ & 20.64 & -12.53 \\
\hline $\mathrm{Pu}-238$ & $1.39 \mathrm{E}+02$ & $1.25 \mathrm{E}+02$ & $3.06 \mathrm{E}+02$ & 120.24 & -10.01 \\
\hline $\mathrm{Pu}-239$ & $3.67 \mathrm{E}+03$ & $3.47 \mathrm{E}+03$ & $5.46 \mathrm{E}+03$ & 48.82 & -5.40 \\
\hline $\mathrm{Pu}-240$ & $2.08 \mathrm{E}+03$ & $1.92 \mathrm{E}+03$ & $2.23 \mathrm{E}+03$ & 7.10 & -7.78 \\
\hline $\mathrm{Pu}-241$ & $6.14 \mathrm{E}+02$ & $5.82 \mathrm{E}+02$ & $5.63 \mathrm{E}+02$ & -8.22 & -5.20 \\
\hline $\mathrm{Pu}-242$ & $3.82 \mathrm{E}+02$ & $3.98 \mathrm{E}+02$ & $2.78 \mathrm{E}+02$ & -27.31 & 4.11 \\
\hline $\mathrm{Am}-241$ & $2.54 \mathrm{E}+02$ & $2.60 \mathrm{E}+02$ & $6.29 \mathrm{E}+02$ & 147.84 & 2.52 \\
\hline
\end{tabular}

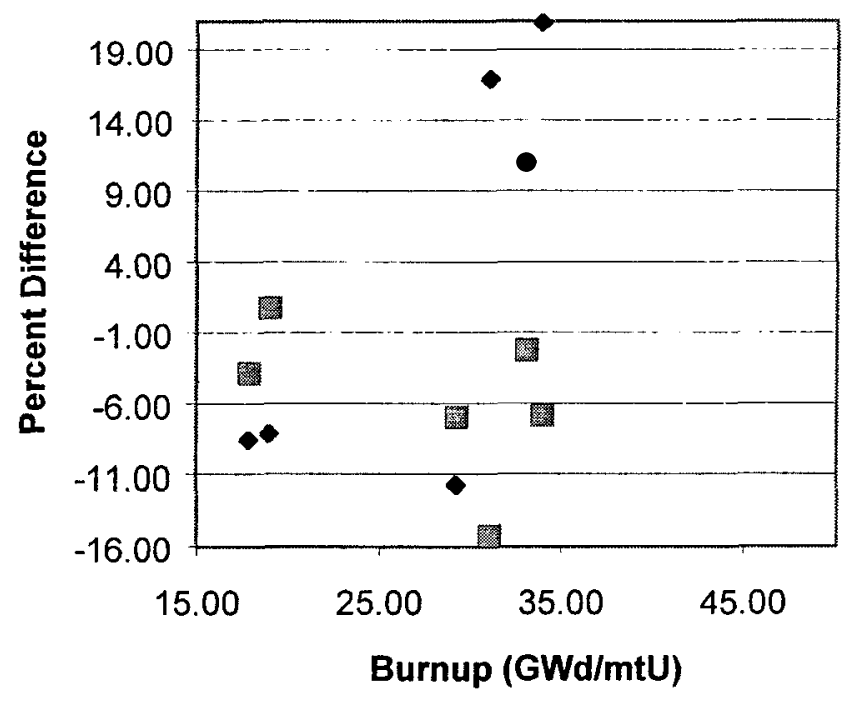

- U-235 GRCASMO3

U-235 SAS2H

Figure 3-21. Cooper U-235 Comparison 


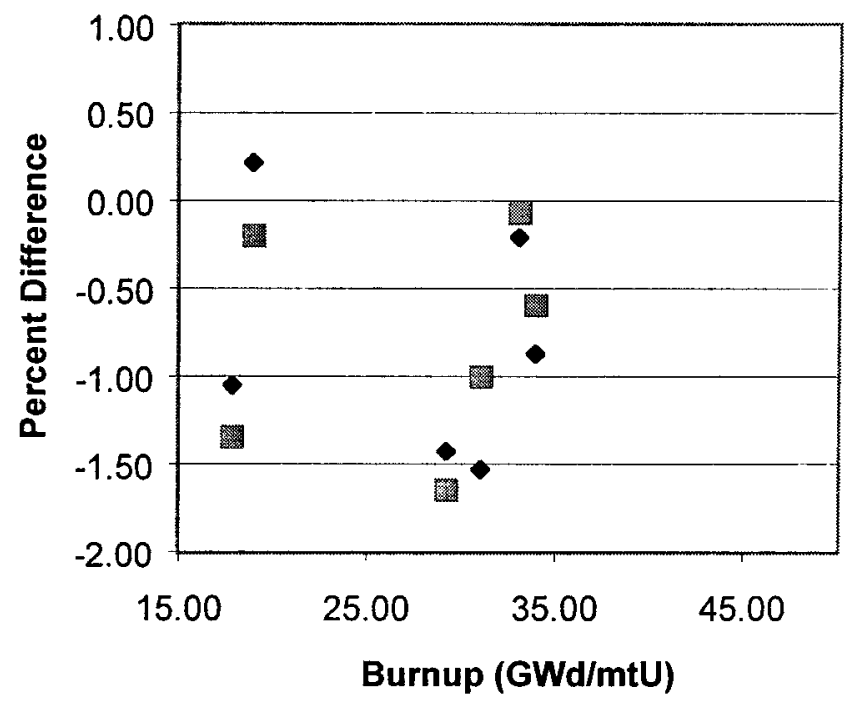

- U-238 GRCASMO3

OU-238 SAS2H

Figure 3-22. Cooper U-238 Comparison

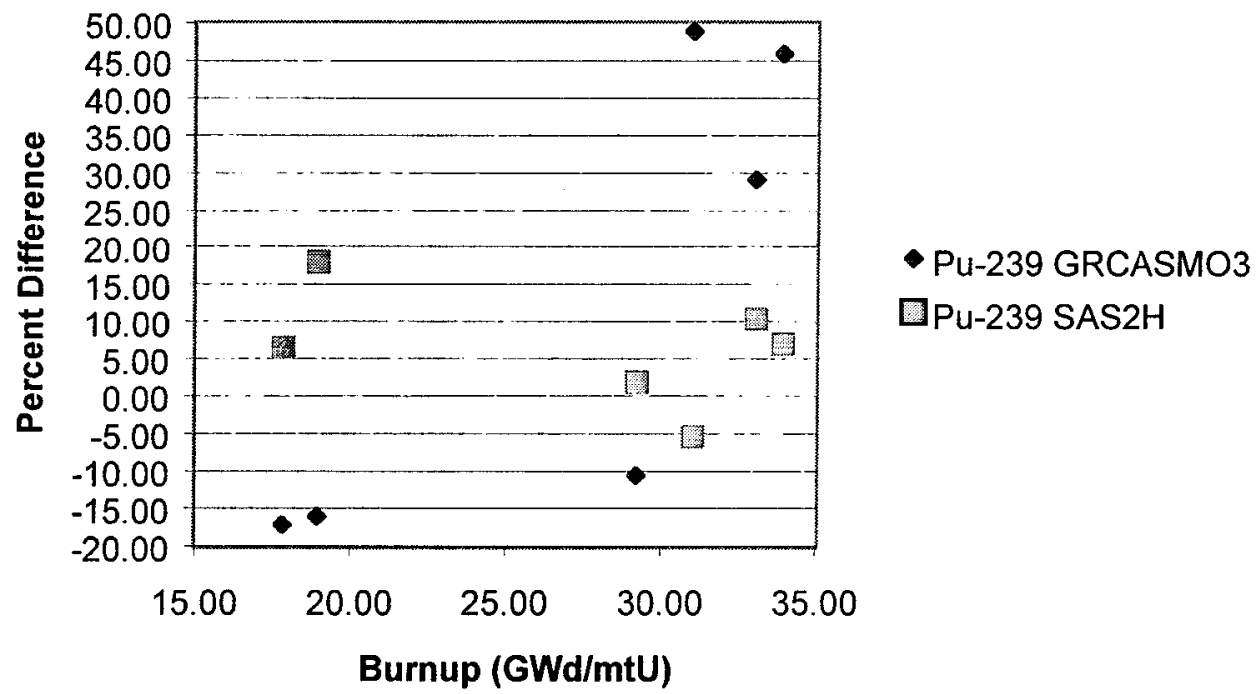

Figure 3-23. Cooper Pu-239 Comparison 


\section{CONCLUSIONS}

The purpose of this summary report was to compare the results from a 2-D fuel depletion code (GRCASMO3) to that of a point depletion code that uses 1-D neutron transport theory weighted cross-sections (SAS2H), and to compare both of these results to the measured values of isotopic concentration from radiochemical assays. In general, the major contributors to reactivity compared favorably between the calculated values and the measured values from the RCAs. Evaluating isotopic concentration results without relating the results to reactivity can be misleading. To quantify the results, two steps are required: (1) both the 2-D and 1-D fuel depletion analyses should be re-run to evaluate the effects of the uncertainty in the RCA results $(+/-0.5 \mathrm{GWd} / \mathrm{mtU})$ and (2) a code should be used to quantify this uncertainty in terms of reactivity

With respect to the Cooper BWR calculations, care must be exercised in using these results. The many assumptions and approximations used in the Cooper BWR calculations limit the usefulness of the results. 
INTENTIONALLY LEFT BLANK 


\section{REFERENCES}

\subsection{DOCUMENTS CITED}

BSC (Bechtel SAIC Company) 2001. Technical Work Plan for: Waste Package Design Description for LA. TWP-EBS-MD-000004 REV 02. Las Vegas, Nevada: Bechtel SAIC Company. ACC: MOL.20011106.0177.

CRWMS M\&O 1997a. SAS2H Analysis of Radiochemical Assay Samples from Calvert Cliffs PWR Reactor. B00000000-01717-0200-00138 REV 00. Las Vegas, Nevada: CRWMS M\&O. ACC: MOL.19971210.0578.

CRWMS M\&O 1997b. SAS2H Analysis of Radiochemical Assay Samples from Cooper BWR Reactor. B00000000-01717-0200-00145 REV 00. Las Vegas, Nevada: CRWMS M\&O. ACC: MOL.19971230.0111.

CRWMS M\&O 1997c. SAS2H Analysis of Radiochemical Assay Samples from H.B. Robinson PWR Reactor. B00000000-01717-0200-00140 REV 00. Las Vegas, Nevada: CRWMS M\&O. ACC: MOL.19971229.0158.

CRWMS M\&O 1997d. SAS2H Analysis of Radiochemical Assay Samples from Mihama PWR Reactor. B00000000-01717-0200-00144 REV 00. Las Vegas, Nevada: CRWMS M\&O. ACC: MOL.19971230.0145.

CRWMS M\&O 1997e. SAS2H Analysis of Radiochemical Assay Samples from Obrigheim PWR Reactor. B00000000-01717-0200-00139 REV 00. Las Vegas, Nevada: CRWMS M\&O. ACC: MOL.19971229.0159.

CRWMS M\&O 1997f. SAS2H Analysis of Radiochemical Assay Samples from Trino Vercelles PWR Reactor. B00000000-01717-0200-00142 REV 00. Las Vegas, Nevada: CRWMS M\&O. ACC: MOL.19971229.0361.

CRWMS M\&O 1997g. SAS2H Analysis of Radiochemical Assay Samples from Turkey Point PWR Reactor. B00000000-01717-0200-00141 REV 00. Las Vegas, Nevada: CRWMS M\&O. ACC: MOL.19971229.0350.

CRWMS M\&O 1997h. SAS2H Analysis of Radiochemical Assay Samples from Yankee Rowe PWR Reactor. B00000000-01717-0200-00143 REV 00. Las Vegas, Nevada: CRWMS M\&O. ACC: MOL.19971230.0156.

CRWMS M\&O 1999. Classification of the MGR Uncanistered Spent Nuclear Fuel Disposal Container System. ANL-UDC-SE-000001 REV 00. Las Vegas, Nevada: CRWMS M\&O. ACC: MOL.19990928.0216. 
DeHart, M.D., and Hermann, O.W. 1996. An Extension of the Validation of SCALE (SAS2H) Isotopic Predictions for PWR Spent Fuel. ORNL/TM-13317. Oak Ridge, Tennessee: Oak Ridge National Laboratory. ACC: MOL.19970930.0475.

DOE (U.S. Department of Energy) 2000. Quality Assurance Requirements and Description. DOE/RW-0333P, Rev. 10. Washington, D.C.: U.S. Department of Energy, Office of Civilian Radioactive Waste Management. ACC: MOL.20000427.0422.

Hermann, O.W.; Bowman, S.M.; Brady, M.C.; and Parks, C.V. 1995. Validation of the Scale System for PWR Spent Fuel Isotopic Composition Analyses. ORNL/TM-12667. Oak Ridge, Tennessee: Oak Ridge National Laboratory. TIC: 245043.

NRC (U.S. Nuclear Regulatory Commission) 1997. SCALE, RSIC Computer Code Collection (CCC-545). NUREG/CR-0200, Rev. 5. Washington, D.C.: U.S. Nuclear Regulatory Commission. TIC: 235920.

YMP (Yucca Mountain Site Characterization Project) 2000. Disposal Criticality Analysis Methodology Topical Report. YMP/TR-004Q, Rev. 01. Las Vegas, Nevada: Yucca Mountain Site Characterization Office. ACC: MOL.20001214.0001.

\subsection{SOURCE DATA, LISTED BY DATA TRACKING NUMBER}

MO0110SPARAD04.009. Two-Dimensional Analysis of Radiochemical Assay Samples. Submittal date: $10 / 17 / 2001$. 


\section{APPENDIX A: SUMMARY PLOTS OF COMPARISON}

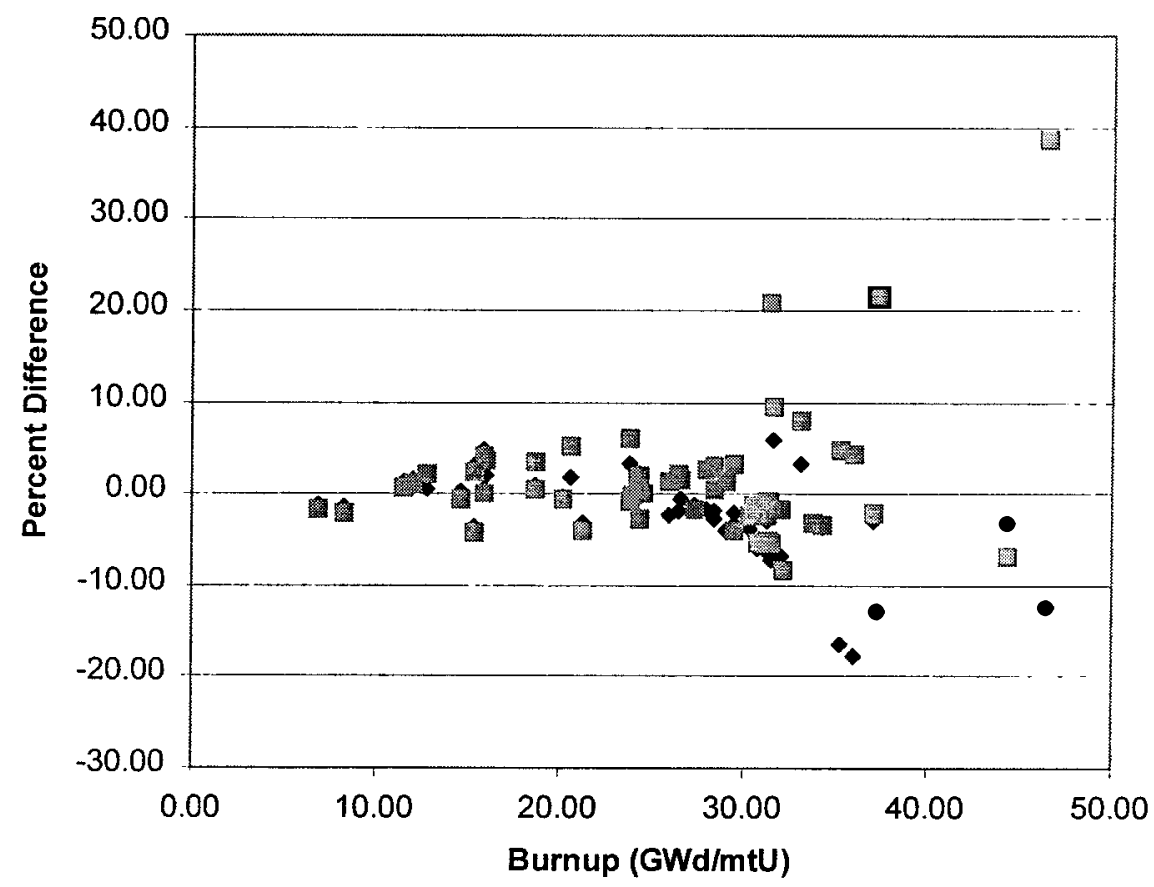

- U-235 GRCASMO3

U-235 SAS2H

Figure A-1. PWR U-235 Summary Comparison

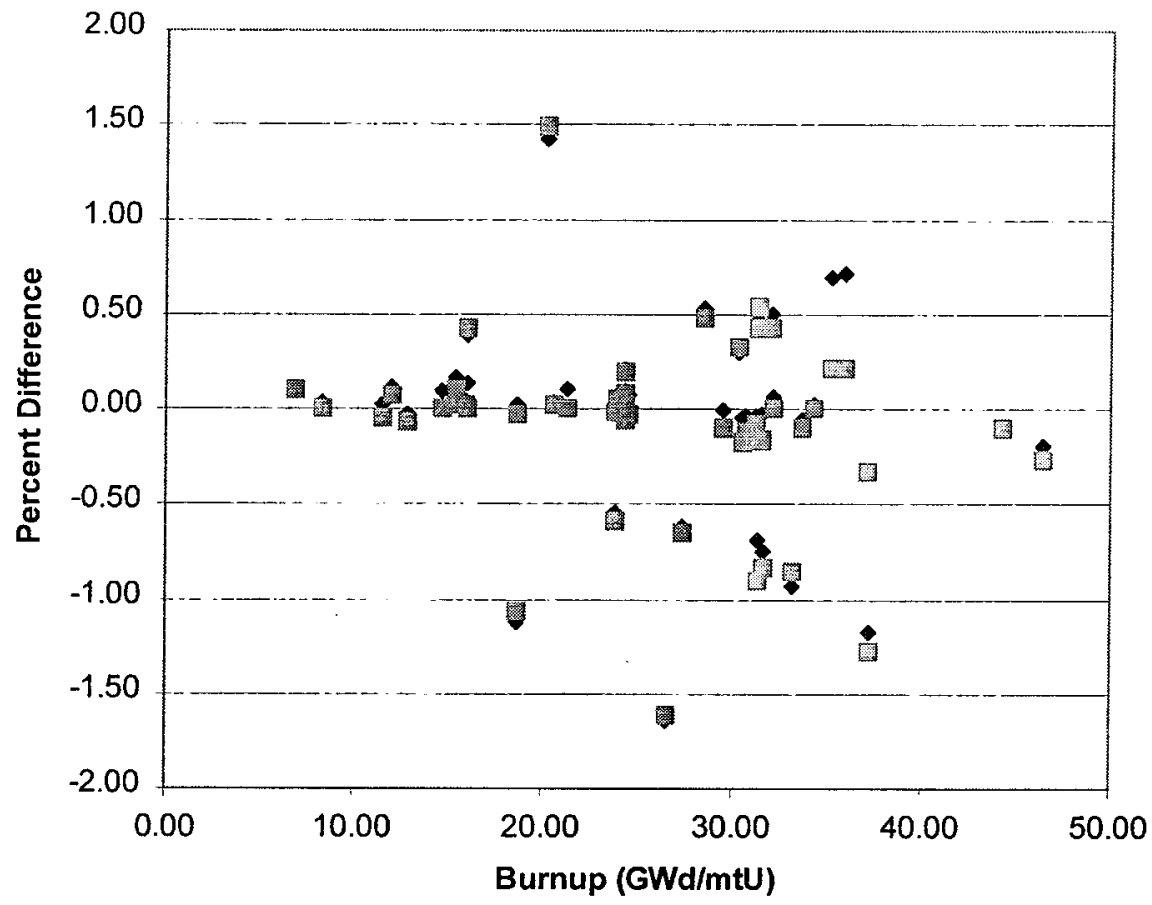

- U-238 GRCASMO3

U-238 SAS2H

Figure A-2. PWR U-238 Summary Comparison 


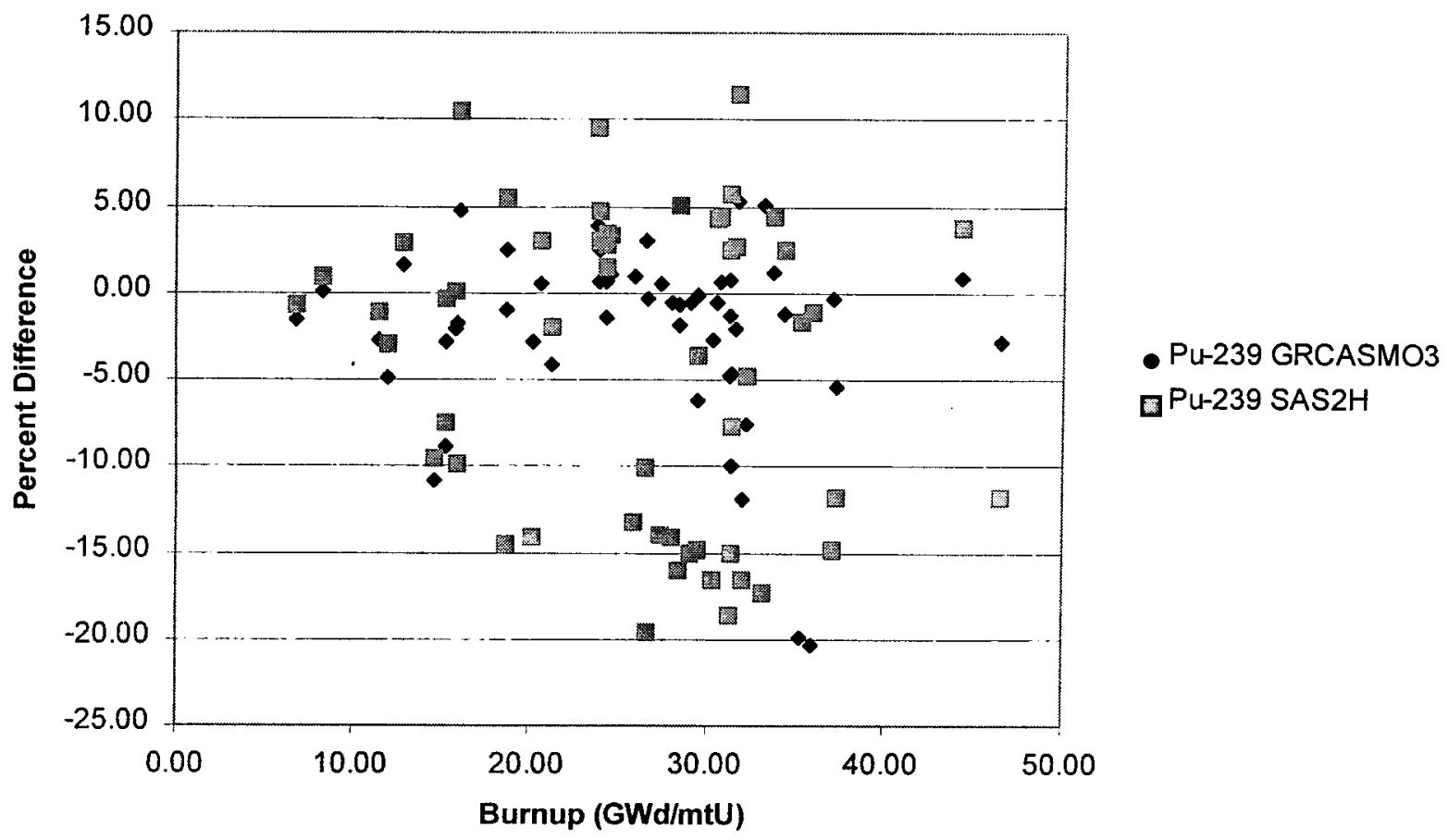

Figure A-3. PWR Pu-239 Summary Comparison 